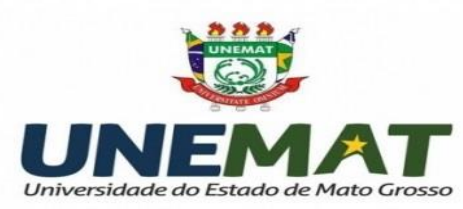

JACKELINE CABRAL LOUREIRO DE ALMEIDA

AQUISIÇÃO DA LEITURA E ESCRITA (LETRAMENTO) COMO SEGUNDA

LÍNGUA (L2) DO ALUNO SURDO: A DISCURSIVIDADE DOS AGENTES

LETRADORES 
JACKELINE CABRAL LOUREIRO DE ALMEIDA

\section{AQUISIÇÃO DA LEITURA E ESCRITA (LETRAMENTO) COMO SEGUNDA LÍNGUA (L2) DO ALUNO SURDO: A DISCURSIVIDADE DOS AGENTES LETRADORES}

Dissertação apresentada à Banca Examinadora do Mestrado em Letras, Linha de Pesquisa Estudos Linguísticos, da Universidade do Estado de Mato Grosso UNEMAT, Campus Universitário de Sinop, como requisito para a obtenção do título de Mestre em Letras.

Orientadora:

Profa. Dra. Sandra Luzia Wrobel Straub 
Walter Clayton de Oliveira CRB 1/2049

\begin{tabular}{|l}
\hline AL47a \\
ALMEIDA, Jackeline Cabral Loureiro de . \\
A Aquisição da Leitura e Escrita (Letramento) Como \\
Segunda Língua (L2) do Aluno Surdo: a Discursividade dos \\
Agentes Letradores / Jackeline Cabral Loureiro de \\
Almeida - Sinop, 2018. \\
120 f.; $30 \mathrm{~cm}$. \\
Trabalho de Conclusão de Curso \\
(Dissertação/Mestrado) - Curso de Pós-graduação Stricto Sensu \\
(Mestrado Acadêmico) Letras, Faculdade de Educação e \\
Linguagem, Câmpus de Sinop, Universidade do Estado de Mato \\
Grosso, 2018. \\
Orientador: Sandra Luzia Wrobel Straub \\
1. Letramento. 2. Libras. 3. Tecnologia Assistiva. 4. Surdez. \\
5. Análise do Discurso. I. Jackeline Cabral Loureiro de Almeida. \\
II. A Aquisição da Leitura e Escrita (Letramento) Como Segunda \\
Língua (L2) do Aluno Surdo: a Discursividade dos Agentes \\
Letradores: . \\
CDU 81'42
\end{tabular}




\section{AQUISIÇÃO DA LEITURA E ESCRITA (LETRAMENTO) COMO SEGUNDA LÍNGUA (L2) DO ALUNO SURDO: A DISCURSIVIDADE DOS AGENTES LETRADORES}

Dissertação apresentada à Banca Examinadora do Mestrado em Letras, Linha de Pesquisa Estudos Linguísticos, da Universidade do Estado de Mato Grosso UNEMAT, Campus Universitário de Sinop, como requisito para a obtenção do título de Mestre em Letras.

BANCA EXAMINADORA

\section{Orientadora}

Profa. Dra. Sandra Luzia Wrobel Straub UNEMAT - Campus Universitário de Sinop

\section{Avaliadora Externa}

Profa. Dra. Cristiane Pereira Dias

UNICAMP - Universidade Estadual de Campinas

Avaliadora Interna

Profa. Dra. Tânia Pitombo de Oliveira UNEMAT - Campus Universitário de Sinop 
À minha irmã Josilene e cunhado Dario, que sempre me incentivaram a alcançar os meus sonhos. À minha mãe pelas palavras de apoio e carinho. Ao meu esposo Gil, companheiro fiel e dedicado. Ao meu filho Matheus, mesmo distante, me motivando. Às minhas princesas Julia e Luiza, que souberam entender os meus conflitos e ausências. 


\section{AGRADECIMENTOS}

Muitos são aqueles a quem tenho que agradecer. Começo, então, por aquele que me criou e me mantém respirando todos os dias, que me proporcionou saúde para concluir mais uma etapa na minha vida, Deus, a Ele toda honra e toda glória.

À minha querida sogra Carmem Brunet, que foi incansável nas orações por mim, mas infelizmente foi tragada pela morte no decorrer da minha caminhada.

À minha mãe Neusa, que me apoiou e me incentivou com palavras de ânimo.

Às minhas cunhadas Rosana e Zair e sobrinhos que torceram/torcem pelo meu sucesso sempre.

Ao carinho incondicional de meu esposo Gil Loureiro, que sempre respeitou minhas escolhas, me motivou, me abraçou e me acolheu nos momentos difíceis, juntamente com nossos filhos Matheus, Julia e Luiza, alicerce do nosso lar.

Agradeço àqueles que foram fundamentais em minha caminhada: minha orientadora, Profa. Dra. Sandra Luzia Wrobel Straub, por sua orientação paciente, com quem achei-perdiachei tantos sentidos nas letras que compõem essa etapa da minha história.

Aos meus professores das disciplinas do mestrado acadêmico em letras da UNEMAT/Sinop, e à coordenadora Profa. Dra. Leandra Ines Seganfredo Santos.

Às professoras da banca examinadora, pelas contribuições: Dra. Tânia Pitombo de Oliveira, Dra. Cristiane Pereira Dias.

Ao grupo de estudos da análise do discurso, "Leituras", coordenado pela Profa. Dra. Cristinne Leus Tomé, e aos colegas participantes, que contribuíram para o meu conhecimento.

Ao grupo de estudos "Educação Científico-Tecnológica e Cidadania”, coordenado pela Profa. Dra. Sandra Luzia Wrobel Straub, pelos ensinos compartilhados e os cursos proporcionados para o meu crescimento intelectual.

Aos meus amigos mestrandos, Graci, Sarah, Romeu, Leandro, Débora, Regina, Maria José e Bonnine Monalliza, pela amizade, encontros/desencontros e estudos compartilhados durante esses dois anos, vocês são nota mil.

À Profa. Dra. Albina Pereira de Pinho, que me motivou, incentivou e acreditou que eu seria capaz de dar um passo a mais.

À Universidade do Estado do Mato Grosso - UNEMAT, pela oportunidade de cursar o PPGLetras, proporcionando-me novos horizontes.

Aos professores, intérpretes de LIBRAS das escolas, que me receberam e participaram desta pesquisa. 
Aos coordenadores pedagógicos, aos diretores das escolas e aos assessores pedagógicos do Estado e à Secretaria Municipal de Educação de Sinop, pelo apoio recebido e a liberação do espaço escolar para a realização da pesquisa.

À CAPES, pela bolsa de estudo no mestrado, sem esta ajuda seria quase impossível dedicar-me aos estudos.

Enfim, a todos que, de maneira direta ou indireta, contribuíram para que este trabalho fosse realizado.

Meu muito obrigada! 
"[...] por trás da mão que pega o lápis, dos olhos que olham, dos ouvidos que escutam, há uma criança que pensa."

(Emília Ferreiro) 


\section{RESUMO}

Embasado no referencial teórico e metodológico da Análise do Discurso Materialista Histórico, iniciada por Michel Pêcheux, este estudo realizou um diálogo entre os agentes letradores do aluno Surdo e a Análise do Discurso, convocando autores desses campos disciplinares: Michel Pêcheux (2009, 2010), Eni Orlandi (1996, 2002, 2004, 2005, 2006, 2007, 2009, 2012, 2013, 2015, 2016), Suzy Lagazzi (1998), Cristiane Dias (2009, 2011, 2016), Mussalim e Bentes (2007), entre outros. Teóricos relacionados à surdez ou ao Surdo e sua língua, como Carlos Skliar (1997, 2003), Ronice Quadros (1995, 1997, 2003, 2004, 2005, 2006), Sueli Fernandes (2006, 2012, 2013), Karin Strobel (2006, 2008), e outros. Teóricos que discutem sobre a Tecnologia Assistiva, Letramentos, Multiletramentos e Alfabetização, tais como: Sandra Straub (2009), Teófilo Galvão (2009, 2012), Magda Soares (1999, 1998, 2004), Leda Tfouni (2010), Emília Ferreiro (1996, 1999), Roxane Rojo (2009, 2012), entre outros, além das principais leis que abordam assuntos sobre Educação Especial, Surdez, Língua brasileira de sinais - LIBRAS e formação de professores. A pesquisa de campo ocorreu entre os anos de 2016 e 2017, em quatro instituições de ensino: duas municipais e duas estaduais, com cinco professoras de sala de aula regular, duas professoras da Sala de Recursos Multifuncionais, três intérpretes de LIBRAS e uma coordenadora pedagógica. Por meio de entrevistas semiestruturadas, orais e transcritas, constituiu-se o corpus para a análise discursiva, com o intuito de mostrar efeitos de sentidos nos discursos produzidos por esses sujeitos-letradores a respeito de suas práticas pedagógicas com os alunos Surdos nas escolas pesquisadas. $\mathrm{Na}$ análise realizada, foram ressaltados os conceitos de língua, sujeito, discurso, condições de produção, ideologia, formações imaginárias, pré-construído, formação discursiva e silenciamento. Nos efeitos de sentidos encontrados, observou-se que os professores não têm o domínio da língua de sinais, e essa falta de conhecimento gera insegurança e insatisfação profissional por não alcançarem, muitas vezes, os objetivos, mas, ao mesmo tempo, motiva-os a buscarem recursos para atender seus alunos dentro do possível. A aquisição da leitura/escrita dos alunos Surdos ocorre parcialmente e a passos lentos, primeiro por desconhecerem a LIBRAS e depois pela falta de conhecimento dos profissionais em como trabalhar a língua portuguesa com o aluno Surdo. Os desempenhos com os multiletramentos são explorados com os Surdos na maioria das vezes pelos intérpretes e na Sala de Recursos Multifuncionais. Na sala regular, utilizam-se materiais didáticos como os que são usados com os ouvintes, por meio da oralidade e livros escolares comuns, o que, para os Surdos, torna inviável o aprendizado. Alguns educadores utilizam-se da Tecnologia Assistiva, no entanto, o fato de não conhecerem bem esse assunto, alegam não ter acesso. Embora os professores busquem melhorias no atendimento, eles consideram que o Estado é o maior responsável pela falta de conhecimento dos profissionais e da inclusão dos Surdos nas escolas.

Palavras-chave: Letramentos. LIBRAS. Tecnologia Assistiva. Surdez. Multiletramentos. Análise do Discurso. 


\begin{abstract}
Based on the theoretical and methodological reference of the Historical Materialist Discourse Analysis, initiated by Michel Pêcheux, this study accomplished a dialogue between the deaf student's literacies agents and the Discourse Analysis, calling on authors of these disciplines: Michel Pêcheux (2009, 2010), Suzy Lagazzi (1998), Cristiane Dias (2009, 2011, 2016), Mussalim and Bentes (2007), among others . Theorists related to deafness or to the Deaf one and his language, such as Carlos Skliar (1997, 2003), Ronice Quadros (1995, 1997, 2003, 2004, 2005, 2006), Sueli Fernandes (2006, 2012, 2013), Karin Strobel , 2008), and others. Theorists who discuss about the Assistive Technology, Literacies, Multiliteracies and Alphabetization, such as: Sandra Straub (2009), Teófilo Galvão (2009, 2012), Magda Soares (1999, 1998, 2004), Leda Tfouni (2010), Emília Ferreiro 1996, 1999), Roxane Rojo (2009, 2012), and others. In addition to the main laws that deal with issues related to Special Education, Deafness, Brazilian Sign Language - (in Portuguese, LIBRAS) and teachers' formation. The Field research took place between 2016 and 2017 in four educational institutions: two from the municipality and two from the state, with five regular classroom teachers, two teachers from the Multifunctional Resource Room, three Brazilian Sign Language interpreters and one pedagogical coordinator. By means of the semi-structured, oral and transcribed interviews, the corpus for the discursive analysis is constituted, in order to show the effects of meanings in the discourses produced by these literacies-subjects, regarding to their pedagogical practices with the deaf students in the studied schools. In the accomplished analysis, the concepts of language, subject, discourse, production conditions, ideology, imaginary formations, pre-constructed, discursive formation and silencing were emphasized. In the encountered sense effects until the present moment, it is observed that teachers do not know the sign language and this lack of knowledge causes on them insecurity and professional dissatisfaction because, many times, they can not reaching the goals, but at the same time it motivates them to search for resources to serve them as much as possible. The acquisition of reading / writing by the deaf students occurs partially and at a slow pace, first, because they are not aware of Brazilian Sign Language and then because of the professionals' lack of knowledge in how to work the Portuguese language with the deaf student. The Multiliteracies performances are explored with the deaf students, most of the time, by the interpreters and by the Multifunctional Resource Room. In the regular classroom, it is used the didactic material equal is used with the listeners, through orality and common textbooks, which becomes learning unfeasible for the deaf ones. It is noted that some educators use the Assistive Technology, however, the fact that they do not know about the issue, they say that don't have access. Although teachers seek improvements in the best assistance, they consider that the Government is the main responsible for the professionals' lack of knowledge .
\end{abstract}

Keywords: Literacies. Brazilian Sign Language (LIBRAS). Assistive Technology. Deafness. Multiliteracies. Discourse Analysis. 


\section{LISTA DE SIGLAS}

AD

AEE

AIE

ARE

CASIES

CEJA

CFB

$\mathrm{CNE} / \mathrm{CP}$

$\mathrm{CP}$

DP

ECA

FD

INES

L1

L2

LDB

LDBEN

LP

LS

LIBRAS

MEC

OCDE

ONU

PNEE

PROLIBRAS
Análise do Discurso

Atendimento Educacional Especializado

Apararelho Ideológico de Estado

Aparelho Repressor de Estado

Centro de Apoio e Suporte à Inclusão da Educação Especial

Centro de Educação de Jovens e Adultos

Constituição Federal Brasileira

Conselho Nacional de Educação / Conselho Pleno

Condição de Produção

Discurso Pedagógico

Estatuto da Criança e do Adolescente

Formação Discursiva

Instituto Nacional de Educação de Surdos

Primeira Língua

Segunda Língua

Lei de Diretrizes e Bases da Educação

Lei de Diretrizes e Bases da Educação Nacional

Língua Portuguesa

Língua de Sinais

Língua Brasileira de Sinais

Ministério da Educação e Cultura

Organização para a Cooperação e Desenvolvimento Econômico

Organização das Nações Unidas

Plano Nacional de Educação Especial

Proficiência em Língua Brasileira de Sinais 
PSRM

SD

SRM

TA

TCLE

TICs

TILS

UFAL

UNESCO
Professor da Sala de Recursos Multifuncionais

Sequência Discursiva

Sala de Recursos Multifuncionais

Tecnologia Assistiva

Termo de Consentimento Livre e Esclarecido

Tecnologias de Informação e Comunicação

Tradutor e Intérprete de língua de sinais

Universidade Federal de Alagoas

Organização das Nações Unidas para a Educação, a Ciência e a Cultura 
INTRODUÇÃ O .....................................................................................................................................9

1 DISCURSO HISTÓRICO DA SURDEZ: ASPECTOS HISTÓRICOS, LINGUÍSTICOS, CULTURAIS E IDENTITÁRIOS ..............................................14

1.1 Breve histórico da educação dos Surdos................................................................... 15

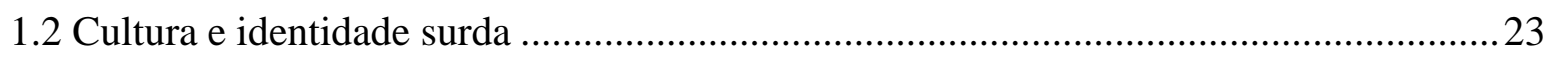

1.3 A realidade das políticas públicas sobre o Surdo na escola: a discursividade dos

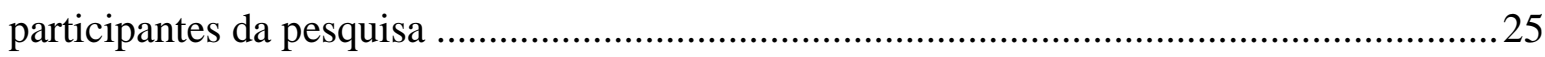

1.4 Aspectos linguísticos da Língua Brasileira de Sinais ................................................29

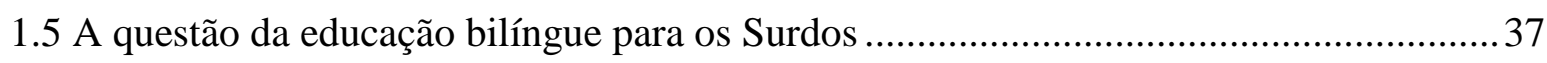

1.6 Letramento no contexto do aluno Surdo.................................................................. 41

2 LETRAMENTO, MULTILETRAMENTOS E TECNOLOGIA ASSISTIVA .............49

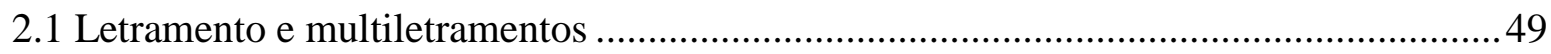

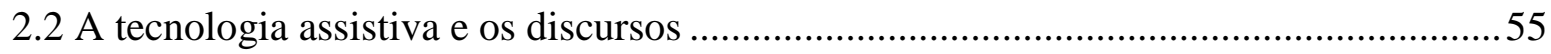

3AS POLÍTICAS PÚBLICAS DA INCLUSÃO AOS SURDOS ........................................65

3.10 sujeito-aluno Surdo, os agentes letradores e os sentidos do discurso jurídico ............68

3.2 A profissão do tradutor e intérprete da língua de sinais - TILS .................................... 74

3.3A Sala de Recursos Multifuncionais (SRM) e os efeitos de sentido nos discursos dos

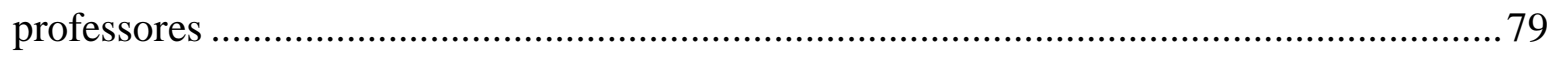

3.4 O discurso dos professores de sala regular sobre a formação para atuação com o aluno Surdo

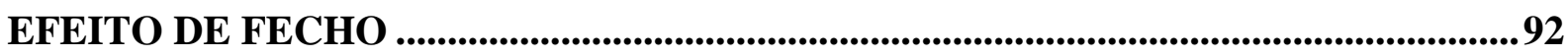

REFERÊNCIAS WEBGRÁFICAS ...................................................................104

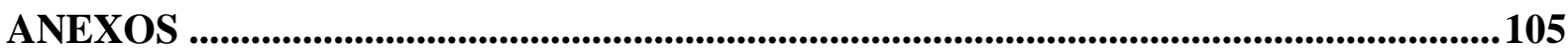




\title{
INTRODUÇÃO
}

\begin{abstract}
"Na língua de um povo, reside toda a esfera de pensamento, sua tradição, história, religião e base da vida, todo o seu coração e sua alma". Isso vale especialmente para a Língua de Sinais, porque ela é a voz - não só biológica, mas cultural, é impossível de silenciar os Surdos."
\end{abstract}

(Oliver Sacks)

Quando falamos de leitura e escrita, muitos equívocos estão historicamente presentes na escola contemporânea. Como exemplo, temos: a relação instrumental com a língua por parte de professores e alunos, o imaginário da transparência da linguagem, a não opacidade do texto e uma relação de completude com uma língua entendida em si mesma, que exclui o sujeito falante em favor de uma metalinguagem nas aulas de língua portuguesa.

O percurso teórico-metodológico desta pesquisatem como objetivo compreender os efeitos de sentidos que emergem na discursividade dos professores de sala de aula regular, professores da sala de recursos multifuncional (SRM) e tradutores e intérpretes de língua de sinais (TILS), no processo de aquisição da leitura/escrita (letramento) da língua portuguesa como segunda língua (L2) para o aluno Surdo.

É importante ressaltar aos leitores que, durante o percurso deescrita deste trabalho, sempre que nos referimos ao Surdo, utilizamos a letra "S" em maiúsculo, porque não podemos caracterizá-lo por sua "deficiência”, mas por ser uma pessoa pertencente a um grupo minoritário constituinte de uma cultura e de uma comunidade própria (MOURA, 2000).

Optamos neste estudo pela pesquisa qualitativa, pois compreendemos que há relação entre o mundo real e o sujeito, uma interdependência viva entre este e o objeto e um vínculo entre o mundo objetivo e a subjetividade do sujeito, onde o sujeito é parte integrante do processo de conhecimento e interpreta os fenômenos atribuindo-lhes significados.

O primeiro passo para a realização deste trabalho foi uma pesquisa documental e teórico-metodológica, o que se tornou uma peça de grande valia na contribuição e no embasamento desta. Esquadrinhamos as leis federais, estaduais e municipais, além de inúmeros autores que pesquisaram sobre esse assunto e que muito contribuíram para o entendimento acerca do objeto de pesquisa.

Para embasamento desta pesquisa, foram realizadas as leituras das principais leis sobre surdez e educação especial, a saber: Lei $\mathrm{n}^{\circ}$ 12.319/10, que dispõe sobre o profissional Intérprete de Língua de Sinais; Lei $n^{\circ}$ 10.436/02, que dispõe sobre o reconhecimento da Língua Brasileira de Sinais - LIBRAS; Constituição Federal de 1988 - CF/88; Estatuto da Criança e do Adolescente - ECA; Declaração de Salamanca; Lei de Diretrizes e Bases da 
Educação - LDB 9.394/96 e Plano Nacional de Educação Especial - PNEE, bem como textos que abordam assuntos acerca da inclusão, o Decreto $\mathrm{n}^{\circ} 5.626 / 05$, que valida à Lei $\mathrm{n}^{\circ}$ 10.436/02, e vários autores que explanam assuntos relacionadoà surdez ou ao Surdo e sua língua, entre eles Carlos Skliar (1997, 2003), Ronice Quadros (1995, 1997, 2003, 2004, 2005, 2006), Sueli Fernandes (2006, 2012, 2013), Karin Strobel (2006, 2008), e outros.

O corpus desta pesquisa delimita-se a escolas públicas estaduais e municipais da educação básica, com a presença de alunos Surdos, na cidade de Sinop, localizada na região amazônica, ao norte do estado de Mato Grosso.

Apoiamo-nos nesta análise na perspectiva teórico-metodológica da Análise de Discurso Materialista Histórica (doravante AD), tendo como precursores e articuladores os autores Michel Pêcheux (2010, 2015), Eni Orlandi (1996, 2002, 2004, 2005, 2006, 2007, 2009, 2012, 2013, 2015, 2016), Suzy Lagazzi (1998), Cristiane Dias (2009, 2011, 2016), Mussalim e Bentes (2007), entre outros.

Nos estudos sobre letramentos, multiletramentos e tecnologia assistiva (TA), apoiamonos em autores como Roxane Rojo (2009, 2012), Magda Soares (1998, 1999, 2004), Leda Tfouni (2010), Emília Ferreiro (1996, 1999), Teófilo Galvão (2009, 2012), Sandra Straub (2009).

Almejamos apresentar as mobilidades dos efeitos de sentidos nos discursos em análise colocando o dito em jogo com o não dito, ou o que está dito em lugares distintos, ou como diz Orlandi (2015a, p. 57), "procurando ouvir, naquilo que o sujeito diz, aquilo que ele não diz, mas que constitui igualmente os sentidos de suas palavras", relacionados às condições de produção do discurso (PD) e suas formações discursivas (FD), por um processo que se inscreve no homem com o simbólico, a história e suas marcas linguísticas.

Segundo Fernandes (2008, p. 13), o discurso tomado como objeto de estudo da AD, "não a língua, nem a fala, nem o texto, mas a necessidade de elementos linguísticos para ter uma existência material”, alude exterioridade à língua, não sendo restrito à linguística por esta ser carregada de aspectos sociais e ideológicos quando as palavras são pronunciadas.

Levando em conta as especificidades da $\mathrm{AD}$, o seu processo analítico é o que temos de mais relevante quando se trata da análise. Orlandi (2015a, p. 59) ressalta que o analista não ocupa uma posição neutra, mas de interpretação, faz-se necessário, então, atravessar os "efeitos da linguagem, da literalidade do sujeito e da onipotência do sujeito".

Para Pêcheux (1990 apud ORLANDI, 2015a, p. 57), "há um outro na sociedade e na história", com um linguajeiro discursivo, ou seja, a relação da possibilidade de interpretar, sendo assim todo enunciado ou toda sequência de enunciados que o descreve linguisticamente 
por um léxico determinado passível de pontos de derivas, esses pontos é que oferecem um lugar de intepretação, e é nesse espaço de deriva que a AD pretende trabalhar. Sendo assim, Orlandi (2015a) argumenta que, em todos os passos da AD, a mediação teórica é intermitente entre a descrição e a interpretação, e é essa mediação que faz a constituição do corpus no processo de compreensão do analista. Na AD implica-se que seja constituído um corpus para que se realize a análise.

Para iniciarmos esta pesquisa, primeiramente foram levantadas as referências teóricas e o percurso metodológico a ser percorrido. Em seguida, foram realizados os procedimentos metodológicos: observação em sala de aula e aplicação das entrevistas com roteiro de perguntas semiestruturadas com o termo de consentimento livre e esclarecido (TCLE) devidamente assinado pelos participantes, conforme rege as normas do comitê de ética.

Durante as entrevistas, utilizamos um gravador de voz para facilitar a coleta dos dados, e o entrevistado discorria livremente dentro do seu entendimento e trabalho, assim foram acrescentando informações conforme a conversa ia fluindo. Nesse aspecto, Trivinos (2010, p. 146) destaca:

Podemos entender por entrevista semiestruturada, em geral, aquela que parte de certos questionamentos básicos, apoiados em teorias e hipóteses, que interessam à pesquisa, e que, em seguida, oferecem amplo campo de interrogativas, fruta de novas hipóteses que vão surgindo à medida que se recebem as respostas do informante. Desta maneira, o informante, seguindo espontaneamente a linha de seu pensamento e de suas experiências dentro do foco principal colocado pelo investigador, começa a participar na elaboração do conteúdo da pesquisa.

Dando continuidade, realizamosa interpretação analítica das entrevistas, a fim de buscar compreender quais sentidos se movem no discurso, as marcas de resistência, ou seja, os sentidos manifestados por meio das falhas e/ou deslizamentos, para mostrar-nos onde os discursos dos sujeitos se contextualizam. Nesse sentido Orlandi (1983 apud LAGAZZI, 1988, p. 61) apresenta-nos que é a partir das marcas linguísticas que se destacam e que se iniciam os caminhos que o analista deverá percorrer no processo discursivo, permitindo-lhe elucidar o funcionamento do discurso, é nesse pleito que esse funcionamento revela-nos a(s) "regularidade(s) enunciativa(s) que se constitui(em) na(s) propriedade(s) desse discurso e que o caracteriza(m) enquanto uma espécie de marca(s)".

Entre os sujeitos desta pesquisa não há uma unicidade, uma vez que os participantes da pesquisa são de escolas diferentes e sua posição sujeito variável (professores de sala regular, professores da SRM e tradutores e intérpretes de língua de sinais - TILS), bem como 
de salas de aulas de diferente grau, mostra que há profissionais que atendem alunos Surdos desde os anos iniciais do ensino fundamental até o terceiro ano do ensino médio da educação básica. Nesse aspecto, tal diferença de lugar revela posições socioideológicas assumidas pelos sujeitos envolvidos, e o discurso torna-se um material de expressão desses lugares. Dessa forma, para Fernandes (2008), a mesma palavra pode ter sentidos diferentes dependendo do lugar socioideológico daqueles que o empregam.

No Primeiro Capítulo deste trabalho, apresentamos a história da Surdez e seus aspectos históricos, linguísticos, culturais e identitários. Trago para discussão os aspectos linguísticos da língua brasileira de sinais, a questão bilíngue para os Surdos e o contexto da alfabetização do aluno Surdo.

No Segundo Capítulo, fazemos uma discussão entre letramento, multiletramentos e tecnologia assistiva, não pretendendo discutir a veracidade, a adequação ou a pertinência que se institui - ou instituiu, como realidade de discursos determinados historicamente, isto é, dos discursos sobre a aquisição da leitura e escrita (letramento) do aluno Surdo na língua portuguesa. Busco, sim, a partir dessa referência enquanto sujeito da enunciação ou, ainda, desse referente como sujeito do enunciado, compreender os efeitos de sentido que emergem no discurso dos agentes letradores, que se constituiu historicamente enquanto sujeito detentor do poder e do conhecimento da e sobre a leitura e escrita da língua portuguesa como segunda língua (L2) do aluno Surdo.

Finalmente no Terceiro Capítulo, colocamos em evidência as políticas públicas em relação à inclusão do aluno Surdo em escolas regulares, a posição sujeito aluno-Surdo e os agentes letradores e os sentidos do discurso. Explanamos sobre a profissão do TILS, os efeitos de sentidos produzidos pelos professores das Salas de Recursos Multifuncionais - SRM, e, os conflitos/confrontos entre formações discursivas referidas ás formações ideológicas na formação dos professores da sala regular, SRM e TILS na atuação com o aluno Surdo.

No efeito de fecho elencamos os efeitos de sentido encontrados nos discursos dos professores quanto às concepções práticas de letramento (aquisição da leitura/escrita) e os multiletramentos utilizados no processo ensino-aprendizagem do aluno Surdo, dentro da perspectiva discursiva dos agentes letradores participantes dessa pesquisa, professores da sala de aula regular, professor da Sala de Recursos Multifuncionais e intérpretes de Língua de Sinais, compreendemos que embora tentassem demonstrar que a aquisição da leitura e escrita da língua portuguesa como L2 e que a inclusão estavam funcionando, percebemos que há uma in/exclusão, ou seja, o aluno está em sala de aula inserido, mas não incluído como o discurso governamental afirma ser/estar. 
Com relação ao uso da TA, observamos que há o uso no processo de ensino e aprendizagem do aluno Surdo na SRM e com os intérpretes, na sala de aula regular o professor não utiliza tal recurso. No entanto eles não entendem como TA, talvez por falta de conhecimento do assunto já que, para Bersch (2013), esse termo Tecnologia Assistiva é novo, ou conforme apresentou em seus discursos, o fato de o nome "Tecnologia" remeter ao imaginário de que são equipamentos digitais.

Percorrido esse trajeto, essa pesquisa nos permitiu compreender o processo que produz $\mathrm{e}$ mantém, ao longo do tempo, sistemas de ensino desiguais, excludentes e contraditórios sobre os quais se construiu a escolarização brasileira, marcada ao longo do tempo, até os nossos dias, por uma "educação de classe" (ORLANDI, 2008, p. 36), ainda que, imaginariamente, a escola seja significada, na discursividade educacional em circulação em nosso país (CURY, 2008), atualmente, como uma escola para todos. 


\title{
1 DISCURSO HISTÓRICO DA SURDEZ: ASPECTOS HISTÓRICOS, LINGUíSTICOS, CULTURAIS E IDENTITÁRIOS
}

\begin{abstract}
"A certeza que aparece, em todo caso, no fim desse debate, é que uma memória não poderia ser concebida como uma esfera plena, cujas bordas seriam transcendentais históricos e cujo conteúdo seria um sentido homogêneo, acumulado ao modo de um reservatório: é necessariamente um espaço móvel de divisões, de disjunções, de deslocamentos e de retomada, de conflitos de regularização... Um espaço de desdobramentos, réplicas, polêmicas e contra discursos."
\end{abstract}

(Michel Pêcheux)

Na epígrafe apresentada, nota-se que o autor Michel Pêcheux interpreta a memória como um fato histórico que não se apresenta de forma calma e plena, mas sim que esta memória traz à mente do sujeito algumas disjunções, deslocamentos, conflitos e polêmicas.

São esses sentidos que acompanham a história dos Surdos, memórias vivenciadas dentro da comunidade surda, relembradas e passadas de geração em geração e que gradativamente eles sistematizam, e estas ganham espaços no mercado editorial, como descreve Fernandes (2012), e, por serem estilizados no passado, eles ambicionam novos rumos, uma identidade própria e respeitada, um novo amanhecer, melhor e digno dentro da sociedade em que vivem.

Por meio do exposto, entende-se que o sujeito Surdo apresenta suas ideologias, e énessacondiçãoideológica que ele constrói seus sentidos. Para Orlandi (2015a), não há discurso sem sujeito e, sendo assim, o discurso desse sujeito é fundamentado na ideologia significante e com efeitos, que se entrelaçam com a língua, a história dando sentidos.

\footnotetext{
A ideologia por sua vez, nesse modo de conceber, não é vista como conjunto de representações, como visão de mundo ou como ocultação da realidade. Não há, aliás, realidade sem ideologia. Enquanto prática significante, a ideologia aparece como efeito da relação necessária do sujeito com a língua e com a história para que haja sentido (ORLANDI, 2015a, p. 44).
}

Ricoeur (1977 apud BRANDÃO, 2012, p. 27) apresenta-nos outro olhar sobre a interpretação. Para o referido autor, a ideologia perpassa por atos iniciais que provocam mudanças na práxis social, não como encenação ou ficção, mas motivando e concedendo argumentos que justifique os interesses dos sujeitos, que "dita as regras de um modo de vida".

É nesse novo cenário que se encontra o Surdo, motivado por seus sonhos e principalmente por seu contexto histórico, e, diante de tanto sofrimento e preconceito, 
iniciaram suas lutas e conquistas a passos lentos, contudo, provocando mudanças significativas na sociedade e, principalmente, na comunidade surda.

\subsection{Breve histórico da educação dos Surdos}

Quando falamos da educação dos Surdos no Brasil, apresentamos um pequeno capítulo de uma longa história vivenciada em todo o mundo. Os Surdos eram hostilizados e sua situação era, na maioria das vezes, uma condição de morte.

Por muito tempo, os Surdos foram vítimas de uma concepção equivocada que vinculava a surdez à falta de inteligência, levando-os a serem marginalizados, com base na crença hegemônica de que, como não poderiam falar, não desenvolveriam linguagem, não poderiam pensar e, portanto, não haveria possibilidades de aprendizagem formal (FERNANDES, 2012, p. 20).

Nesse sentido, Guarinello (2004) nos remete à ideia do filósofo Aristóteles, quando este afirmava que, para atingir a consciência, fazia-se necessário a atuação dos órgãos do sentido, no caso o canal auditivo, o mais importante desses órgãos e essencial para o aprendizado, pois no passado acreditava-se que a fala era a responsável pelo pensamento.

Uma vez que o Surdo era desprovido desse sentido, certamente por alguma "maldição dos deuses", entendia-se, então, que não pensavam, e essa falta de sentido fazia com que estes ficassem trancafiados e fossem tratados muitas vezes como bichos.

Posteriormente, houve o reconhecimento de que o sujeito Surdo não é totalmente desprovido de audição e que seus restos auditivos poderiam ser desenvolvidos, no entanto, eles continuaram a enfrentar preconceitos sem piedade, sendo considerados como loucos. Salles et al. (2004) complementa, ainda, que o sujeito Surdo não se enquadrava no padrão normal da sociedade, por esse motivo, era abandonado ou isolado desta. Skliar (1997) afirma que na China os Surdos eram lançados no mar pelos gauleses como sacrifícios aos deuses Teutates.

Nos anos de 1501, surgiu um italiano, matemático, médico e astrólogo, por nome Gerolano Cardano, argumentando que a surdez não coibia o conhecimento e utilizando a escrita para provar o seu dito, porém sua metodologia não foi aceita (ARRUDA, 2003).

A possibilidade de humanização dos Surdos como pessoas capazes de serem instruídas surgiu na Idade Moderna. Isso se deu devido ao nascimento de Surdos na realeza, e, mesmo com o costume de se manter sigilo absoluto, alguns professores se dispuseram a prestar seus serviços na educação dos filhos Surdos da nobreza (SALLES et al., 2004). 
Dessa forma, apregoa Lacerda (1998) que os professores trabalhavam de forma isolada, não havendo troca de experiências, por esse motivo, argumenta o autor que muito se perdeu na educação dos Surdos, o que não pode ser reconstituído. Os avanços na educação dos Surdos vieram a partir dessa época, quando se começou a acreditar que os Surdos poderiam aprender se houvessem métodos pedagógicos adequados.

No século XVI, surgiu um marco na educação do Surdo: o monge espanhol Pedro Ponce de Leon desenvolveu a datilologia, ou seja, o alfabeto em Língua de Sinais para os Surdos. Lodi (2005) nos relata que o trabalho do monge foi de grande importância e influenciou os métodos utilizados posteriormente por outros educadores de Surdos.

Ainda, nesse sentido, Souza (1998) complementa dizendo que a utilização dos métodos visuais, como a datilologia, foi um progresso valioso na aprendizagem do Surdo. Com o desenvolvimento do método Ponce de Leon, viu-se a possibilidade de o Surdo tornarse cidadão, a fim de responder por si próprio, administrar os negócios da família e receber suas heranças, uma vez que se comunicasse por meio da fala e/ou escrita.

Mais tarde, no século XVIII, surgiram novos educadores de Surdos, a saber: "o alemão Samuel Heineck (1729-1970), o inglês Thomas Braidwood (1715-1806) e o abade francês Charles Michel de L'Epée (1712-1789)", que desenvolveram diferentes metodologias educacionais para o Surdo (SALLES et al., 2004, p. 54).

Em 1780, na França, o abade L'Epée apresentou uma forma de educação de Surdos misturando o francês escrito com a Língua de Sinais, ou seja, o francês sinalizado, e esse método trouxe-lhe prestígio perante o governo da França, o qual resolveu apoiar criando a primeira escola pública para Surdos no país, intitulada Instituto de Surdos-Mudos de Paris (REIS, 1992). Na visão de Sacks (1990, p. 37), o abade criou ações simples efáceis, ideias precisas para que os seus pupilos aprendessem com mais facilidade:

[...] uma arte metódica, simples e fácil, pela qual transmitia a seus pupilos idéias de todos os tipos e até mesmo, ouso dizer, ideias mais precisas do que as geralmente adquiridas através da audição. Enquanto a criança ouvinte está reduzida a julgar o significado de palavras ouvidas, e isto acontece com frequência, elas aprendem apenas o significado aproximado; e ficam satisfeitas com essa aproximação por toda a vida. É diferente com os Surdos ensinados por L'Epée. Ele só tem um meio de transmitir ideias sensoriais: é analisar e fazer o pupilo analisar com ele. Assim, ele os conduz de ideias sensoriais e abstratas; podemos avaliar como a linguagem de ação de L'Epée é vantajosa sobre os sons da fala de nossas governantas e tutores.

Segundo Silva (2003) mesmo com o sucesso dos ensinos de L’Epée, este foi duramente criticado justamente pela utilização da Língua de Sinais com os Surdos. Os críticos 
acreditavam que a Língua de Sinais era desprovida de uma gramática e, portanto, impossibilitaria que os Surdos fossem reflexivos.

No ano de 1857, o francês Ernest Huest criou o Instituto Nacional de Educação dos Surdos - Ines. Ele veio para o Brasil a convite do Imperador D. Pedro II a fim de trabalhar com os Surdos, nascia, então, a educação de Surdos no Brasil.

Após tão importantes revelações, espalhou-se por diferentes países e principalmente na França a notícia de que havia possibilidade de educação aos Surdos sem a intervenção de forças místicas, sobrenaturais ou religiosas, o que deu lugar à atuação do pedagogo. (FERNANDES, 2012). Iniciou-se, a partir daí, pesquisas e debates intermináveis de dois grupos: os que queriam provar que os Surdos poderiam ser educados por meio de gestos ou mímicas, como eram denominados na época, e outro grupo que dizia ser a fala uma língua universal, portanto essa deveria prevalecer independente de se ser Surdo ou ouvinte. (FERNANDES, 2012). Em síntese, "historicamente, o foco das atenções na educação dos Surdos esteve voltado às questões linguísticas e não propriamente pedagógicas". (SKLIAR, 1997 apud FERNANDES, 2012, p. 24).

No ano de 1878, segundo Arruda (2003) na cidade de Paris, realizou-se o primeiro Congresso Internacional de Surdos-Mudos, momento em que, entre tantas propostas, falou-se dos métodos de ensino de Surdos utilizando a melhor maneira de articulação e leitura labial, porém o método gestual foi mantido para que houvesse comunicação entre professores e alunos.

Entre os anos de 1930 e 1970, o Dr. Armando Paiva Lacerda assumiu a direção do Ines e desenvolveu a Pedagogia Emendativa do Surdo-Mudo, a fim de trazer novamente o método oral como uma maneira única de incluir o Surdo na sociedade. Ele também utilizava métodos assustadores quanto à definição dos Surdos-Mudos, separando-os conforme o grau de inteligência, estipulado após serem submetidos a um teste de aptidão (HONORA, 2009).

A representação do Dr. Armando Paiva apresenta-nos um discurso puramente autoritário, pois, como aborda Orlandi (2016, p. 152) para fazer sentido, a língua, sujeita a falhas (divisão), se inscreve na história, produzindo discursividade. Nesse sentido, para a autora supracitada, o sujeito é atravessado por posições e sentidos que o constituem em formações diferentes, o que o faz definir o que o sujeito "pode e deve fazer numa situação dada em uma conjuntura dada, e refletem, no discurso, as formações ideológicas" (ORLANDI, 2016, p. 152). Ainda, para a autora, a concepção autoritária está refletida na forma de linguagem que possuímos, em deslizes ideológicos, atribuídos a algo que é histórico e que "se dá em relação à dominância de um tipo de discurso, numa certa formação social” (ORLANDI, 1996, p. 76). 
$\mathrm{Na}$ década de 1970, com a visita de Ivete Vasconcelos, educadora de Surdos da Universidade Gallaudet, chegou ao Brasil a filosofia da Comunicação Total e, na década seguinte, a partir das pesquisas da professora linguista Lucinda Ferreira Brito, sobre a Língua Brasileira de Sinais, e da professora Eulália Fernandes, sobre a educação dos Surdos, o Bilinguismo passou a ser difundido. Atualmente, estas "três filosofias educacionais (oralismo, comunicação total e bilinguismo) ainda persistem paralelamente no Brasil” (HONORA, 2009, p. 21).

Para essas três correntes de pensamento, Sá (1999) faz a seguinte explanação: a abordagem educacional oralista tem como finalidade fazer com que o sujeito Surdo utilize o oralismo do sujeito ouvinte. Já a Comunicação Total utiliza-se de meios diversificados na comunicação do Surdo, tais como fala, escrita, sinais e gestos, no entanto a abordagem defendida por Surdos e profissionais da área é a do Bilinguismo, respeitando a língua de sinais como a língua materna (L1) e a língua portuguesa como segunda língua (L2).

No ano de 1987, no Rio de Janeiro, um grupo de três Surdos resolveu fundar a Federação Nacional de Educação e Integração dos Surdos - Feneis e tambémextinguiram a Federação Nacional da Educação e Integração dos Deficientes Auditivos - Feneida, que era administrada por pessoas ouvintes, o que foi considerado um marco para os Surdos, pois, a partir daí, começaram a gerenciar sua própria identidade, criando e fortalecendo a comunidade surda.

As mudanças, então, foram acontecendo com grande relevância desde esse momento: discussões sobre a educação e a metodologia a ser empregada no ensino aos Surdos tem sido motivo de debates contínuo nos congressos, governo e comunidade surda. Porém, a concepção do sujeito Surdo, a aceitação da sua língua e a relação entre ouvintes e Surdos é o que torna urgente o entendimento de que são necessárias leis que viabilizem e incentivem o uso da Língua de Sinais no intuito de facilitar a educação dos Surdos dentro da sala de aula (SKLIAR, 1997).

Para Skliar (1997, p. 109) a educação dos Surdos foi marcada por dois períodos: o primeiro vai da metade do século XVIII à primeira metade do século XIX, ao qual ele deu o nome de período prévio, e o segundo período, conhecido como tempo de escuridão, nome criado pela comunidade surda devido à proibição do uso da Língua de Sinais ocorrida no Congresso de Milão no ano de 1880, lembrando que na ocasião os professores Surdos foram proibidos de votar. 
Vergamini (2003) relata que a violência linguística sofrida pelos Surdos através da proibição da língua de sinais deixou rastros permanentes vivenciados até os dias de hoje. Segundo Vergamini (2003, p. 27):

Devido às proibições de compartilhar uma língua cultural do povo Surdo em resultado emitido pelo Congresso Internacional de Educadores de Surdos ocorrido em Milão, na Itália, no ano de 1880, o uso de língua de sinais foi definitivamente banido a favor da metodologia oralista nas escolas de Surdos e até hoje sofremos consequências deste episódio.

Em outros termos, a forma como os Surdos são tratados está ligada diretamente à historicidade dos acontecimentos. Para Perlin e Strobel (2006) esse evento foi considerado o maior em questão de preconceito e repreensão contra os Surdos na língua de sua cultura. Dessa forma, Skliar (1997) declarou que o Congresso de Milão (1880) legitimou oficialmente tal repreensão como uma ideologia oralista.

Nesse sentido trazemos Angenot (1984 apud ORLANDI, 2007a, p. 110) o qual retrata que, quando o discurso social é abordado em um consenso que fora colocado em funcionamento por uma formação social, ele recobre exclusivamente a um dos aspectos dos processos de significação do efeito já dito, sendo uma noção de discurso imaginário já produzido, que se depara no âmbito da formulação e não da constituição do discurso, o que vem ao encontro da situação vivenciada pelos Surdos no momento do silenciamento, no qual se produziu um discurso imaginário idealizado na formação discursiva de que os Surdos poderiam ser oralizados se privados da sua língua materna.

Para a Análise de Discurso Materialista, a linguagem e os sujeitos são indissociáveis, articulando-se à história a que fazem parte o imaginário e a ideologia. Orlandi (2015a, p. 40) afirma que o imaginário faz parte do funcionamento da linguagem, não surgiu do nada, mas de um contexto histórico.

[...] na análise de discurso, não menosprezamos a força que a imagem tem na constituição do dizer. $\mathrm{O}$ imaginário faz necessariamente parte do funcionamento da linguagem. Ele é eficaz, ele não "brota" do nada: assentase no modo como as relações sociais se inscrevem na história e são regidas, em uma sociedade como a nossa, por relações de poder (ORLANDI, 2015a, p. 40, grifo do autor).

Para Skliar (1997) após a proibição do uso dos sinais, o sentimento de inferioridade espalhou-se na comunidade surda, o que deixou um sentimento de que essas transformações não tiveram caráter educativo e sim puramente político, filosófico e religioso. 
De acordo com Orlandi (2015a) é notório que na sociedade em geral existem hierarquias em que se exercem as relações de força e poder independentes dos lugares em que estão ocupando. Ainda sobre as relações de força, Harouche (1987 apud ORLANDI, 2015a, p. 48) mostra-nos que, com os novos sentidos da sociedade, o sujeito passa a ser dono de si, e aquela subordinação ora vivenciada em tempos remotos dá lugar à subordinação do discurso religioso, tirando-lhes o direito de escolha e mostrando o quanto o sujeito demonstra assujeitamento às ideologias e às relações de força e poder.

Soares (1999) lamenta que, após o Congresso de Milão, o oralismo passou a ocupar uma grande parte na educação dos Surdos nos fins do século XIX e uma considerável parte no século XX. Entre as várias diretrizes sugeridas em Milão, apenas a da oralidade foi aceita por unanimidade de votos, portanto os governos deveriam tomar as medidas cabíveis e fazerem com que todos os Surdos tivessem uma educação oralizada. Tal decisão nos remete à fala de M. Pêcheux (1990 apud ORLANDI, 2016, p. 152) quando diz que "todo enunciado é constituído por pontos de deriva", uma vez que a linguagem se confronta com o político, sendo o político o detentor do poder:

Todo enunciado é constituído por pontos de deriva, podendo deslizar para um outro, diferente de si mesmo, produzindo assim diferentes sentidos para diferentes sujeitos e situações, já que não há linguagem que não se confronte com o político. E o político, simbolizando as relações de poder, reside na divisão dos sujeitos e dos sentidos já que a nossa formação social é regida pela diferença, pela divisão, pela dispersão.

As decisões tomadas no Congresso de Milão, para Sacks (1998) também mostram que o oralismo trouxe grandes atrasos na comunicação dos Surdos, pois eles não conseguiam se comunicar com os ouvintes e ficavam isolados da sociedade. O ato de silenciar os Surdos (proibir a língua gestual) causou-lhes um abismo na sociedade, e a decisão de proibir o uso da língua de sinais dificultou a comunicação, a linguagem, porém o Surdo continuou na conquista e na luta pelos seus direitos e pelo significado de sua vida. Orlandi (2007a, p. 76) afirma que, ao proceder com o discurso da censura, o sujeito fica proibido de ocupar certos "lugares" ou algumas posições, pois esta censura está entrelaçada com o discurso produzido em diferentes formações discursivas que estão relacionadasà situação momentânea.

Perlin e Strobel (2006, p. 17) manifestaram-se sobrea Língua de Sinais afirmando que a proibição de seu uso ocasionou um “empobrecimento linguístico cultural e cognitivo" para os Surdos. No entanto, os Surdos agora teriam grandes desafios de construir uma história cultural, a fim de trazerem para a sociedade o reconhecimento das diferenças e o respeito por 
sua cultura, deixarem de sofrer todas as opressões provenientes dos ouvintes e oralistas, e mostrar a importância da Língua de Sinais para a representação de sua identidade.

\begin{abstract}
A proibição da Língua de Sinais por quase 100 anos sempre esteve viva nas mentes dos povos Surdos até hoje, no entanto, agora o desafio para o povo surdo é construir uma nova história real, com o reconhecimento e o respeito das diferenças, valorização de sua língua, a emancipação dos sujeitos Surdos de todas as formas de opressão ouvintistas e seu livre desenvolvimento espontâneo de identidade cultural (PERLIN; STROBEL, 2006, p. 17).
\end{abstract}

Foram necessários quase 100 anos para que novamente, no primeiro Congresso Mundial dos Surdos em 1971, agora em Paris, os educadores reconhecessem a pobreza linguística dos Surdos e aceitassem a Língua de Sinais na educação destes. Nesse congresso os governantes entenderam que os sujeitos Surdos obtiveram um retardo na aprendizagem e grandes malefícios foram gerados na cultura surda (SACKS, 1998).

Após esse Congresso, no ano de 1981, muitos governantes e estudiosos levantaram-se em defesa não só dos Surdos, mas também de outros deficientes, e este foi considerado o ano Internacional da Pessoa Portadora de Deficiência pela Organização das Nações Unidas ONU, e nesse mesmo ano a Língua de Sinais foi reintroduzida na vida dos Surdos, conquista realizada por meio da Federação Mundial dos Surdos (MOURA, 2000).

Aos poucos, os deficientes vêm adquirindo espaço na sociedade, mas, apesar da demora, tem-se alcançado grandes conquistas. Podemos observar tal vitória quando na Conferência Mundial de Educação Especial em Salamanca, no ano de 1994, parágrafo primeiro, na qual foi reafirmado o compromisso com uma educação para todos,

Nós, os delegados da Conferência Mundial de Educação Especial, representando 88 governos e 25 organizações internacionais em assembleia aqui em Salamanca, Espanha, entre 7 e 10 de junho de 1994, reafirmamos o nosso compromisso para com a Educação para Todos, reconhecendo a necessidade e urgência do providenciamento de educação para as crianças, jovens e adultos com necessidades educacionais especiais dentro do sistema regular de ensino e reendossamos a Estrutura de Ação em Educação Especial, em que pelo espírito de cujas provisões e recomendações governo e organizações sejam guiados (SALAMANCA, 1994, p. 1).

Considerando que os Surdos necessitam de um atendimento diferenciado por terem uma língua diferente e gestual, as conquistas apresentaram maiores vitórias perante as leis e os decretos da Educação Especial quando foram promulgados: Lei Federal n 9 9.394/96, Decreto n 3.298/99 e Lei nº 7.853/89, que apresenta a seguinte declaração: “A pessoa com deficiência tem direito à educação pública e gratuita na rede regular de ensino e, ainda, à educação 
adaptadaàs suas necessidades especiais" (BRASIL, 1996, grifo nosso). Nota-se que há um discurso de igualdade perante os homens quando se diz que "tem direito à educação pública", portanto há uma memória funcionando no jurídico de forma "pressuposta", a qual está produzindo um efeito do pré-construído, porque, perante a lei, presume-se que todos são iguais, fato este que está sustentado em uma visão sujeito-histórica capitalista (ORLANDI, 2016).

Esse pequeno trecho da lei mostra-nos que os Surdos têm direito a uma educação na sua língua materna (L1), ou seja, na Língua Brasileira de Sinais - LIBRAS, porque, quando o texto diz "educação adaptada", está se referindo ao português para a língua de sinais, no entanto, sabe-se que para o sujeito Surdo a sua língua é a materialidade gestual e/ou corporal, o que torna impossível separá-la dele.

Sendo assim, suas mãos ou corpo fazem parte das relações simbólicas operando efeitos de sentido tal qual o efeito do ato da fala para o ouvinte. Dessa forma, reportamos a Strobel quando este define que o sujeito Surdo passa a reconhecer e desenvolver a sua identidade pessoal a partir do momento em que reconhece sua diferença de sujeito ouvinte e expressa a sua relação com o mundo.

O sujeito surdo, ao conhecer e vivenciar a história de surdos, desenvolve a sua identidade pessoal, do "eu", começa a ter uma visão mais sistematizada acerca da sua diferença e do povo surdo em que vive, através de suas descobertas e discussões, enxerga o mundo, discute, descreve e escreve o que vê, o que sente em relação ao seu ser surdo. Ele exterioriza a sua subjetividade e desenvolve sua auto-estima (STROBEL, 2008, p. 41, grifo do autor).

Uma grande conquista da Comunidade Surda Brasileira e de seus usuários deu-se após a promulgação da Lei $\mathrm{n}^{\mathrm{o}}$ 10.436, de 24 de Abril de2002, quando o Congresso Nacional reconheceu a LIBRAS como a segunda língua brasileira.

Art. $1^{\circ}$ É reconhecida como meio legal de comunicação e expressão a Língua Brasileira de Sinais - LIBRAS e outros recursos de expressão a ela associados.

Parágrafo único. Entende-se como Língua Brasileira de Sinais - LIBRAS a forma de comunicação e expressão, em que o sistema linguístico de natureza visual-motora, com estrutura gramatical própria, constitui um sistema linguístico de transmissão de ideias e fatos, oriundos de comunidades de pessoas Surdas do Brasil (BRASIL, 2004). 
No dia 22 de dezembro de 2005, o presidente Luiz Inácio Lula da Silva assinou o Decreto $n^{\circ} 5.626$, que regulamenta a Lei $n^{\circ} 10.436 / 02$, que dispõe sobre a LIBRAS e o art. 18 da Lei $n^{\circ}$ 10.098/00, que garante o direito a educação às pessoas com deficiência auditiva, defende o bilinguismo, ou seja, o uso de duas línguas: a LIBRAS (L1) e a Língua Portuguesa (L2).

Durante todo o período da educação dos Surdos, houve mudanças significativas em muitos aspectos em questão à educação especial. No entanto, Fernandes (2013) lamenta que, embora a Libras seja hoje oficial pela Lei Federal, ela ainda segue desconhecida e sem prestígio, além de ter uma carga de preconceito e ignorância por parte de muitos no convívio social e, principalmente no meio educacional.

\subsection{Cultura e identidade surda}

"O primeiro artefato da cultura surda é a experiência visual em que os sujeitos Surdos percebem o mundo de maneira diferente, a qual provoca as reflexões de suas subjetividades: De onde viemos? O que somos? Para onde queremos ir? Qual é a nossa identidade?"

(STROBEL)

O trecho da autora citado em epígrafe apresenta-nos as condições do sujeito Surdo ao descobrir-se em meio a uma sociedade ouvinte, um sujeito estilizado, sem saber quem é e qual o seu papel na sociedade.

A cultura surda é compreendida como identidade cultural de grupos de Surdos que se definem diferentes de outros grupos (QUADROS, 2006). Na AD, essa diferença está relacionada à minoria, na ilusão de uma falsa democracia e igualdade no discurso (MASSMANN, 2014).

Dessa forma, define Silva (2000, p. 69) que "identidade" é um conjunto que diferencia os grupos sociais dos grupos culturais. Ainda para Silva (1999, p. 134), a cultura está relacionada ao poder, situando-se na conexão entre "cultura, significação, identidade e poder".

Sendo assim, Massmann (1999, p. 13) traz em suas pesquisas que essa cultura, identidade e poder estão entrelaçados à ideologia com o material político, de forma inconsciente, sendo parte do sujeito, com uma cultura pensada na forma positivista relacionada à política, "fazendo vizinhança com a racionalidade, aquilo que se representa como visível, claro, explicável ou não".

Nesse entremeio, o sociólogo da Universidade de Gallaudet Anderson (1994 apud BARROS E LOPES, 2016, p. 116) relata que "a cultura dos Surdos sinaliza que as normas, os 
valores, a tecnologia e a linguagem dos Surdos são diferentes de outros grupos humanos".

Em um estudo mais aprofundado de Barros e Lopes (2016, p. 118), sobre o que é cultura?, observa-se a teoria de Michel De Certeau (2014) que diz: "Cultura não é apenas um conjunto de práticas, mas as definiçõoes do ato de fazer, das práticas no movimento da vida social". Para as referidas autoras, essa teoria de Certeau compreende que a sociedade se transforma apresentando a cultura como natural de um povo ou grupo, como se já estivesse lá, tornando-se um efeito ideológico. No entanto, Massmann (2014, p. 14) afirma que toda cultura apresenta uma apropriação, uma transformação pessoal e uma troca de um grupo social, não nascendo de um "déficit do pensamento ou se nutrindo do desprezo do outro".

Pensando desse modo é que Hall (1997, p. 12) afirma: “Cultura é uma das condições constitutivas de existência dessa prática, que toda prática social tem uma dimensão cultural, [...] e que toda prática social tem o seu caráter discursivo".

Quadros (2006) defende que a identidade cultural é compreendida como um processo social discursivo, com experiências multifacetadas e características específicas do grupo ao qual pertence, esse grupo, ao receber experiências visuais, traduz em línguas de sinais, de forma que se manifestam grupos dos próprios Surdos. Dessa forma entendemos que

Estudos Culturais, como campo do saber, possibilitam se ocupar com muitos e diferentes significados e significantes culturais que tramitam politicamente nas diferentes forças de poder, agrupando-os, demarcando os diferentes espaços culturais inerentes a cada cultura (PERLIN, 2006, p. 66).

Percebemos que, quando falamos de cultura ou identidade surda, o campo é vasto e há várias temáticas que se associam a essa investigação: sua história, sua língua, o movimento surdo, as diferençasimpostas e tantas discussões de políticas públicas. O autor Carlos Skliar (2005, p. 5), exímio estudante da comunidade surda, define os Estudos Surdos da seguinte forma:

Os Estudos Surdos se constituem enquanto um programa de pesquisa em educação, onde as identidades, as línguas, os projetos educacionais, a história, a arte, as comunidades e as culturas surdas são focalizados e entendidos a partir da diferença, a partir do seu reconhecimento político.

No entanto Massmann (2014, p. 123) afirma que, quando pesquisadores dos Estudos Surdos denominam a comunidade ou a cultura dos Surdos apenas em sujeitos Surdos que fazem o uso da língua de sinais, estão estereotipando e rotulando-os, fazendo com que o trabalho do "político no simbólico se ocupe de estabelecer modos de identificação dos/para os sujeitos sociais com que praticam comportamentos, hábitos já socialmente significados, 
estabilizados em sua significação, promovendo o efeito de evidência de que todo sujeito Surdo (sem audição)", pertença ao mesmo grupo cultural.

Diante do exposto, buscamos respaldo na $\mathrm{AD}$ na compreensãodos processos de significação provocando efeitos de sentidos na vida do sujeito de forma que se coloque a interpretá-los. Assim "no mundo [...] há diferentes maneiras de significar, [...] homens falando [fazendo sinais, desenhando, dançando], considerando a produção de sentidos enquanto parte de suas vidas, seja enquanto sujeitos, seja enquanto membros de uma determinada forma de sociedade”. (MASSMANN, 2014, p. 122).

Desse modo, para finalizarmos a questão cultural do sujeito Surdo, utilizaremos a fala de Pêcheux (1990) apud Massmann (2014, p. 65): “É na linguagem que o homem é afetado pela língua de diferentes modos, não tendo controle sobre a maneira de como isso se dá, pois subjetiva-se na relação com a língua, a história e a ideologia, mesmo sem fazer uso de uma estrutura linguística”.

\subsection{A realidade das políticas públicas sobre o Surdo na escola: a discursividade dos participantes da pesquisa}

Para compreensão dos efeitos de sentido dos agentes letradores na atuação com o sujeito-aluno Surdo em nosso processo investigativo, tivemos a colaboração da rede pública de ensino do município de Sinop/MT. Participaram de nossa pesquisa quatro escolas que fazem parte da rede estadual e municipal de ensino e que trabalham com alunos Surdos nas salas de aula, a saber: uma do Ensino Médio, uma da Educação de Jovens e Adultos e duas do Ensino Fundamental, divididas as turmas da seguinte forma:

- Escola Municipal de educação básica, localizada em um bairro próximo ao centro da cidade, que recebe alunos oriundos dos bairros próximos. Nessa escola a pesquisa deu-se com a professora do $2^{\circ}$ ano fundamental que tem uma aluna Surda em sala, esta não conhece a língua de sinais e não possui intérprete de língua de sinais, e a escola possui Sala de Recursos Multifuncional (SRM).

- Escola Municipal de educação básica, localizada em um bairro afastado do centro, recebe alunos oriundos dos bairros vizinhos e vindos de regiões rurais em ônibus escolar. A professora participante da pesquisa tem domínio da língua de sinais e ministra aula de português para o $3^{\circ}$ e o $5^{\circ}$ ano do ensino fundamental, tendo um aluno Surdo em cada turma, os dois possuem intérprete de língua de sinais. A escola possui Sala de Recursos 
Multifuncional - SRM, porém os alunos Surdos não fazem uso desta porque a escola possui sala L1/L2 na qual as intérpretes trabalham com eles em turno contrário.

- Escola Estadual de Educação de Jovens e Adultos (CEJA), que atende do $6^{\circ}$ ano do ensino fundamental ao $3^{\circ}$ ano do ensino médio, localiza-se na região central e recebe cerca de cento e cinquenta alunos oriundos de diversas regiões da cidade, os quais utilizam os transportes escolares (ônibus). Essa escola assiste desde o jovem até ao idoso que, por algum motivo, não concluiu os estudos na fase adequada. A professora participante da pesquisa ministra aula de português ao $9^{\circ}$ ano do ensino fundamental, não conhece a língua de sinais, tem um aluno Surdo na sala acompanhado por intérprete de língua de sinais, a escola possui SRM a qual o aluno tem participação assídua em turno contrário.

- Escola Estadual de Ensino Médio localizada na região central de Sinop, esta recebe alunos oriundos de todo o município, que fazem uso de ônibus escolar. Os professores participantes da pesquisa são todos graduados em língua portuguesa; o professor do $1^{\mathrm{o}} \mathrm{e}$ do $2^{\circ}$ ano do ensino médio tem um aluno Surdo em cada sala, e o professor do $3^{\circ}$ ano tem uma aluna Surda em sala, todos contam com um intérprete de língua de sinais, e nenhum é graduado, tendo somente o documento de certificação de proficiência em Libras. A escola possui SRM, e os alunos recebem atendimento com a professora da sala de SRM em turno contrário, com acompanhamento do intérprete por esta não conhecer a língua de sinais.

- Os participantes da pesquisa (Quadro 1).

\section{QUADRO 1: AGENTES LETRADORES PARTICIPANTES DA PESQUISA}

\begin{tabular}{|c|c|c|}
\hline Área de atuação & Formação & Sala de atuação \\
\hline $\begin{array}{c}\text { Professor } 1 \\
\text { (P.1 sala regular) }\end{array}$ & $\begin{array}{l}\text { Licenciatura em } \\
\text { Letras/Inglês }\end{array}$ & $\begin{array}{c}3^{\circ} \text { ano do Ensino Médio da Escola } \\
\text { Estadual }\end{array}$ \\
\hline $\begin{array}{c}\text { Professor } 2 \\
\text { (P.2 sala regular) }\end{array}$ & $\begin{array}{l}\text { Licenciatura em } \\
\text { Letras/Espanhol }\end{array}$ & $\begin{array}{c}1^{\circ} \text { e } 2^{\circ} \text { ano do Ensino Médio da } \\
\text { Escola Estadual }\end{array}$ \\
\hline $\begin{array}{c}\text { Professor } 3 \\
\text { (P.3 sala regular) }\end{array}$ & $\begin{array}{l}\text { Licenciatura em } \\
\text { letras/Inglês }\end{array}$ & $\begin{array}{l}9^{\circ} \text { ano do Ensino Fundamental da } \\
\text { Escola Estadual }\end{array}$ \\
\hline $\begin{array}{c}\text { Professor } 4 \\
\text { (P.4 sala regular) }\end{array}$ & Pedagogia & $\begin{array}{c}2^{\circ} \text { ano do Ensino Fundamental da } \\
\text { Escola Municipal }\end{array}$ \\
\hline $\begin{array}{c}\text { Professor } 5 \\
\text { (P.5 sala regular) }\end{array}$ & Pedagogia & $\begin{array}{l}3^{\circ} \text { e } 5^{\circ} \text { ano do Ensino } \\
\text { Fundamental da Escola Municipal }\end{array}$ \\
\hline $\begin{array}{l}\text { Professor SRM } 1 \\
\text { (PSRM 1) }\end{array}$ & $\begin{array}{c}\text { Letras/Inglês } \\
\text { Intérprete profissional }\end{array}$ & $\begin{array}{l}\text { SRM do Ensino Fundamental da } \\
\text { Escola Estadual }\end{array}$ \\
\hline Professor SRM 2 & Pedagogia & SRM do \\
\hline
\end{tabular}




\begin{tabular}{|c|c|c|}
\hline (PSRM 2) & & Ensino Médio na Escola Estadual \\
\hline $\begin{array}{c}\text { Intérprete Libras } 1 \\
\text { (TILS 1) }\end{array}$ & Ensino superior & $\begin{array}{l}3^{\circ} \text { ano do Ensino Médio, Escola } \\
\text { Estadual }\end{array}$ \\
\hline $\begin{array}{c}\text { Intérprete Libras } 2 \\
\text { (TILS 2) }\end{array}$ & Ensino médio & $\begin{array}{l}1^{\circ} \text { ano do Ensino Médio, Escola } \\
\text { Estadual }\end{array}$ \\
\hline $\begin{array}{l}\text { Intérprete Libras } 3 \\
\text { (TILS 3) }\end{array}$ & Ensino médio & $\begin{array}{l}9^{\circ} \text { ano do Fundamental, Escola } \\
\text { Estadual }\end{array}$ \\
\hline Coordenadora & Pedagoga & $\begin{array}{c}2^{\circ} \text { ano do Ensino Fundamental da } \\
\text { Escola Municipal }\end{array}$ \\
\hline
\end{tabular}

Fonte: Elaborado pela pesquisadora a partir dos dados da pesquisa.

Estes são os espaços aos quais os agentes letradores, participantes de nossa pesquisa, pertencem. Espaço, conforme Orlandi (2016) é idealizado e emoldurado de todos os fenômenos.

Faz-se pertinente relatar que das escolas pesquisadas somente uma coordenadora e duas professoras da SRM participaram da pesquisa, as demais não aceitaram colaborar com o processo de investigação. Podemos dizer que houve um silenciamento no dizer desses profissionais, um silêncio interdito que rege as ações do sujeito, dos sentidos, do discurso, dos gestos de interpretação, entre outros muitos sentidos (ORLANDI, 2007).

O silêncio é assim, a "respiração" da significação; um lugar de recuo necessário para que se possa significar, para que o sentido faça sentido. Reduto do possível, do múltiplo, o silêncio abre espaço para o que não é "um", para o que permite o movimento do sujeito (ORLANDI, 2007a, p. 13, grifo do autor).

O princípio basilar da $\mathrm{AD}$ é que não há discurso sem sujeito e não há sujeito sem ideologia, assim, para a $\mathrm{AD}$, o sujeito é um sujeito empírico, um sujeito físico que funciona no discurso, na posição sujeito discursivo (ORLANDI, 2006). O não querer dizer dos envolvidos no processo educacional com o aluno Surdo pode ser significativo no processo escolar.

Segundo Pêcheux (1990 apud ORLANDI, 2006), o sujeito carrega com ele as marcas do social, das ideologias, do histórico. No livro "Análise Automática do Discurso" (AAD), Althusser (1970 apud P. HENRY, 2010) apresenta o sujeito enquanto efeito ideológico elementar, ou seja, nada é por acaso, nada é consequência de alguma coisa. Nesse mesmo sentido, Althusser (1965 apud P. HENRY, 2010, p. 31) complementa que, enquanto sujeito, qualquer pessoa é "interpelada" a ocupar um determinado lugar no sistema de produção, ou seja, ninguém se torna sujeito, mas que este é sempre já-sujeito e que "todo sujeito humano 
social só pode ser agente de uma prática social enquanto sujeito". Com esse mesmo pensamento, Orlandi (2005, p. 100) reafirma tal posição quando diz que o sujeito é interpelado pela ideologia, e que esta provoca um efeito ideológico no qual "o sujeito sendo sempre-já sujeito, coloca-se na origem do que diz”. Assim a não participação do sujeitocoordenador e do sujeito-professor da SRM pode ter sido motivada, entre outras possibilidades, pela ideologia apresentada por esses agentes letradores, ou ainda, a presença do aluno Surdo no ambiente escolar provoca uma desestabilização de sentidos, isto é, os professores precisam pensar/falar sobre o que desconhecem. Por outro lado, apreocupação do não saber já aponta para uma reflexão, talvez uma mudança de postura.

No livro "Discurso e Texto" (p. 99), no capítulo "Do sujeito na História e no Simbólico", Orlandi afirma que "o sujeito, na análise de discurso, é posição entre outras, subjetivando-se na medida mesmo em que se projeta de sua situação (lugar) no mundo para sua posição no discurso". Apresenta aqui a posição social/empírico do sujeito que ocupa uma posição específica no discurso. Não há possibilidade de ser mais ou menos sujeito, ou mais ou menos subjetivado, porque não há como quantificar o assujeitamento.

Para Orlandi (2005, p. 100), o assujeitamento está interligado à qualificação do sujeito na relação constitutiva com o simbólico, ou seja, "se é sujeito pelo assujeitamento à língua, na história, não há nem sujeito nem sentido se não houver assujeitamento à língua".

Reforçando, Orlandi (2006) compreende que a ideologia transforma o indivíduo em sujeito, que se submete à língua significando-se pelo simbólico na história. Em Orlandi (2012, p. 99), "a AD é a forma de conhecimento que realiza em seu objeto - o discurso - a conjunção desses três modos de opacidade: a do sujeito, a da língua e a da história".

No livro "Análise de Discurso: princípios e procedimentos” (p. 44), Orlandi apresenta a ideologia como condição na constituição do "sujeito e dos sentidos", ou seja, o indivíduo é “interpelado pela ideologia para que se produza o dizer". Desse modo, segunda a referida autora, para que haja sentido, na relação de ordem simbólica, é necessário que a língua como “sistema sintático passível de jogo - de equívoco, sujeita a falhas se inscreva na história".

Enfim, para a AD, a análise necessita de uma mudança de solo, ou que se denomina de ruptura metodológica, com uma ideia fundamental do estudo de significação e propõe a intervenção de conceitos a respeito das formações sociais que fazem parte da reflexão (ORLANDI, 2009).

De acordo com Orlandi (1996), o fato de escolhermos partes dos trechos dos discursos faz-se necessário para a organização do material coletado e uma gama muito grande de material coletado passível de análise. Há várias formas de separar o material de análise, nós 
escolhemos recortes que tratam do assunto em questão para nos proporcionar uma caracterização do funcionamento discursivo. Contudo vale ressaltar que como analista não poderíamos deixar de citar a frase de Orlandi (2017) ${ }^{1}$ : “[...] nós, analistas, não podemos confundir nossos objetos de análise com o nosso objeto teórico que é o discurso".

O currículo escolar associado à pratica docente determina, em grande parte, a forma como os alunos, de modo geral, vão significar-se para si, para os outros, e a forma como a sociedade os significará. Em um artigo publicado na "Revista Rua" (2015a, p. 197), Orlandi nos traz que, para compreendermos o processo de significação que agrega "ensino, conhecimento e sociedade", por meio da relação professor e aluno, é necessário observar que nesta relação se faz presente o Estado, "enquanto articulador simbólico com o político, e a ideologia que parte do processo de constituição dos sujeitos e dos sentidos”. Sendo assim, no decorrer deste trabalho, compreenderemos melhor como esse processo se constituiu.

\subsection{Aspectos linguísticos da Língua Brasileira de Sinais}

Quando falamos sobre língua, fala e linguagem, remetemo-nos ao pai da Linguística, Ferdinand Saussure. Para Saussure (2006, p. 22), não há como separar a língua da fala, não há como separar o que é individual e o que é social, pois a língua é importante para que a fala se faça inteligível, e a fala é necessária para que a língua se estabeleça; enquanto a língua é produto da fala, quem faz a fala evoluir é a língua. Ainda para Saussure a língua é social e independe do indivíduo, no entanto é o indivíduo que produz a fala, sendo assim, faz-se necessária a soma da língua com a fala para que haja a produção.

Para o autor, a linguagem é heterogênea e faz parte da língua, ainda que a língua seja delimitada e de natureza homogênea, linguagem esta que pode ser manifestada de diversos modos, tais como: visual, imagético, escrito, sinalizado e gestual. Assim, língua e linguagem são apresentadas em dois níveis: o biológico e o social. Para Orlandi (2009) existem duas tendências para a Linguística, a saber, o formalismo, que, segunda a autora, ocupa o percurso psíquico da linguagem e faz uma ligação entre linguagem e pensamento, e a segunda ela chama de sociologismo, que explora as relações entre linguagem e sociedade, esta estuda o percurso social.

De acordo com Fernandes (2013) o bilinguismo encaixa-se nesses dois níveis de linguagem. Segundo a autora, a Língua Brasileira de Sinais define a língua da comunidade

\footnotetext{
${ }^{1}$ Cf. III Jornada e-Urbano - Sujeitos e Sentidos nas Margens: há um fora do digital? 15 e 17 de agosto de 2017, Laboratório de Estudos Urbanos - Unicamp.
} 
surda como uma língua visual-espacial. Nesse sentido, Quadros e Karnopp (2004) afirmam que a língua de sinais é natural e compartilha de características específicas que a distinguem dos demais sistemas de comunicação.

As línguas de sinais são consideradas línguas naturais e, consequentemente,
compartilham uma série de características que lhes atribui caráter específico
e as distingue dos demais sistemas de comunicação. As línguas de sinais são,
portanto, consideradas pela linguística como línguas naturais ou como um
sistema linguístico legítimo, e não como um problema do surdo ou como
uma patologia de linguagem. É uma língua que atende a todos os critérios da
língua genuína, na sintaxe, no léxico e na forma de gerar quantidades
significativas de sentenças (QUADROS; KARNOPP, 2004, p. 30).

A alocução remete-nos novamente ao pai da Linguística, quando nos adverte que a linguagem não pode ser observada como uma condição única de episódios humanos por ser impossível de deparar a sua unidade; na verdade a fala de Saussure nos remete ao pensamento de que o funcionamento da linguagem acomoda-se nessa interdependência entre língua e fala.

Como se imaginaria associar uma ideia a uma imagem verbal, se não se surpreendesse de início essa associação num ato de fala? Por outro lado, é ouvindo os outros que aprendemos a língua materna; ela se deposita em nosso cérebro somente após inúmeras experiências (SAUSURRE, 2006, p. 27).

Durante anos a língua de sinais foi nomeada linguagem de sinais, mas, com estudos aprofundados acerca do assunto, firmou-se que o termo adequado para classificá-la seria línguas naturais.

No Brasil a língua de sinais passou a ser estudada na década de 90 do século XX. Quadros (2004) atribui as primeiras descobertas a respeito dessa língua e seus parâmetros a Gladis Knak Rehfeldt, sendo esta a primeira autora a estudá-la no Brasil.

No percurso das pesquisas de Karnopp e Quadros, elas concluíram que "uma criança surda para adquirir a língua de sinais acontece análoga à aquisição da linguagem em crianças adquirindo uma língua oral-auditiva" (QUADROS, 2006, p. 20). Ainda para Karnopp e Quadros (2007, p. 30) a língua de sinais como língua natural conceitua-se em "uma realização específica da faculdade da linguagem que se dicotomiza num sistema abstrato de regras finitas, as quais permitem a produção de um número limitado de frase”. Para as autoras, a língua de sinais é uma língua materna natural dos Surdos, que não está veiculada ao canal oral-auditivo, dessa forma a língua gestual-visual proporciona-lhes o desenvolvimento linguístico, cognitivo e social. 
Em relação ao discurso de Quadros, trazemos Orlandi (2002) a qual escreve que se o discurso não estiver em posição oposta ao sistema em suas constantes, a língua não corresponderá à noção de fala, ou seja, o discurso tornará uma prática social que se abre ao funcionamento na medida em que é colocado em pertinência ao social e ao histórico.

Para Brito (1998) as línguas de sinais são naturais; assim como as línguas orais surgiram instintivamente da influência mútua entre pessoas ouvintes, as línguas de sinais também surgiram entre pessoas Surdas, permitindo a manifestação de conceitos diversos, tais como racional, emocional, literal, enfim, que demonstra a necessidade comunicativa e expressiva da humanidade.

\subsubsection{Estrutura Sintática}

A LIBRAS é uma língua gestual com regras e estrutura. A distinção entre a LIBRAS e as línguas orais é que ela (LIBRAS) se utiliza de uma visão-espacial, ou seja, precisamos olhar onde o emissor (quem passa a mensagem) está direcionando os movimentos e a mensagem que está transmitindo, não podendo desviar o olhar para outros acontecimentos, o que não ocorre com a língua oral que o receptor (quem recebe a mensagem) precisa somente ouvir para entender o que se pretende (HONORA, 2009).

Nota-se que esse processo de comunicação, para Jakobson (2001), se desenvolve de forma satisfatória se o remetente, que envia a mensagem, passa um contexto apreensível e de referência ao destinatário, o que recebe a mensagem, sendo esse código total ou parcial, mas que sejam interpretados por ambos de forma que os mantenha em comunicação. Quando ele trata desse assunto, ele está falando da teoria da informação verbal, mas que cabe muito bem na forma de comunicação com os Surdos, já que a língua destes é por sinais e gestos, sendo totalmente interpretativos.

O posicionamento de Honora (2009, p. 41) é de que "a LIBRAS possui uma estrutura ou mecanismos morfológicos, sintáticos e semânticos". Para a autora, a Língua de Sinais apresenta ser viva por ser uma língua que está em constante transformação através de novos sinais, que são introduzidos pela comunidade surda quando necessário.

Quadros e Karnopp (2006) atribui grande parte dos estudos linguísticos da língua de sinais e das descobertas das complexidades desta língua ao autor Willian Stokoe ${ }^{2}$, que, segundo as

\footnotetext{
${ }^{2}$ Willian Stokoe (1920-2000) foi um dos primeiros linguistas a estudar uma língua de sinais com tratamento linguístico. Considerado o pai da linguística da língua de sinais americana. Comentário retirado do artigo "Língua de Sinais I", publicado em 2009 por Ronice Quadros.
} 
autoras, comprovou que a língua de sinais assim como a língua oral possui regras gramaticais, permitindo conceitos abstratos e uma grande quantidade de sentenças.

A LIBRAS é uma língua com características próprias e não é universal, com uma estrutura diferenciada para cada país, assim como é na língua oral, mesmo nos lugares onde se falam a mesma língua como é o caso de Brasil e Portugal, diferenciando cada um conforme sua cultura (HONORA, 2009).

Segundo Strobel e Fernandes (1998) essa diferença acontece porque foram produzidas nas comunidades surdas independente da língua oral. As autoras salientam ainda que a língua de sinais também apresenta variações no seu dialeto de região para região, o que comprova o fato de ela ser mais natural do que se possa pensar.

Além das mudanças universal e regional, as autoras Strobel e Fernandes afirmam que a Língua de Sinais também tem suas variações históricas. "Com o passar do tempo, um sinal pode sofrer alterações decorrentes dos costumes da geração que o utiliza" (STROBEL; FERNANDES, 1998, p. 3).

A língua de sinais, segundo Brasil (2004, p. 86) é reconhecida por nomes diferentes nos cinco continentes ${ }^{3}$. As línguas de sinais não podem ser confundidas com gestos ${ }^{4}$ ou mímicas $^{5}$ por não terem as mesmas características ou as estruturas gramaticais como a LIBRAS.

Para Quadros e Karnopp (2006, p. 48) a Língua de Sinais, por ser natural e formada por um sistema linguístico legítimo, compartilha características específicas que a tornam diferente dos outros sistemas de comunicação que "atende a todos os critérios linguísticos de uma língua genuína, no léxico, na sintaxe e na capacidade de gerar uma quantidade infinita de sentenças”.

Durante as entrevistas realizadas nesta pesquisa, pudemos perceber, por meio dos discursos dos professores que entendem, essa diferença de estrutura gramatical da LIBRAS para a Língua Portuguesa.

\footnotetext{
${ }^{3}$ LIBRAS/LSB - Língua de Sinais Brasileira; LGP - Língua Gestual Portuguesa; ASL - Língua Americana de Sinais; LSF - Língua Francesa de Sinais; HSE - Hausa Sign Language (Nigéria); LIS - Língua Italiana dei Segni; LSA- Língua de Sinais Argentina e Australiana; LSC- Língua de Sinais Chilena; JSL - Língua de Sinais Japonesa; LSQ - Língua de Sinais Québecois. A definição de gestos no dicionário é: Movimento do corpo, principalmente das mãos, braços e cabeça.

${ }^{5}$ A definição de Mímica no dicionário é: Arte de imitar, de exprimir os pensamentos por meios de gestos e da expressão fisionômica.
} 


SD1 ${ }^{6}$ - Ele escreve no jeito deles, aquela linguagem do verbo sempre no
infinitivo, aquele jeito então que ele aprende sem conjugações e sem a
interligação, ou tento fazer de uma forma oral, no caso "oral" em partes pra ele em
conceito de sinal, eu faço perguntas pra ele, pra ele mostrar a interatividade dele
em formas de sinal pra sala, pra ver se ele entende o conteúdo, então ele passa da
forma "oral" pra nós, aí ele fica participativo. (P. 2, sala regular)
SD2 - Eles lêem, mas eles não conseguem ainda explicar tudo que está dentro
do texto, porque tem muitas palavras que eles ainda não conhecem, apesar de que na
sala de recurso a gente acaba fazendo uso dessas imagens para que ele associe,
então em textos curtos, há essa explicação, essa compreensão bem clara, dentro da
sala regular são textos mais densos, para leitura isso já acaba ficando um pouco
mais difícil. (PSRM 1).

Quando na SD1 o professor de sala regular assume sobre o aluno: "Ele escreve no jeito deles", o uso da expressão "no jeito deles", "aquele jeito" define que o professor considera o Surdo como um aluno dotado de características diferentes do universo que a determina, porque o identifica com particularidades que não são identificadas nos outros alunos e nem em si mesmo. Sendo assim, busca a interação e acredita que, ao fazê-lo se comunicar, torna-o participativo. No entanto, o fato de o professor não saber a linguagem de LIBRAS e não conseguir a efetiva comunicação tem a ilusão de que, ao fazer intervenções orais e sinais, está atingindo os objetivos de aprendizagem.

Nesse sentido Strobel e Fernandes (1998) esclarecem que a LIBRAS não deve ser estudada com a mesma estrutura sintática da língua portuguesa. Por ser uma língua visualespacial, ela possui uma estrutura sintática própria, não seguindo a ordem da língua oral na construção do enunciado.

Ainda na SD1 podemos observar que o professor faz uma observação de que o seu aluno Surdo escreve “o verbo sempre no infinitivo", e continua: "ele aprende sem conjugações e sem a interligação". Para Strobel e Fernandes (1998) a LIBRAS, por possuir regras próprias, não se utiliza de artigos, preposições ou conjunções, porque estes já estão incorporados ao sinal. Em relação aos pronomes possessivos, a LIBRAS não marca para o gênero do discurso, pois o Surdo relaciona as pessoas ao discurso e não à posse como no português. Para o uso de pronomes definidos ou indefinidos, na LIBRAS não há diferença, tudo depende do contexto em que está inserido o enunciado e as expressões faciais realizadas.

O uso de códigos diferenciados (Português e LIBRAS), limitados pela falta de conhecimento dos códigos utilizados entre os interlocutores, determina a quebra da comunicação. Quando se utilizam os mesmos códigos, os gestos de interpretação entre os

\footnotetext{
${ }^{6}$ Encontram-se em destaque em negrito os discursos analisados dos dizeres dos agentes letradores.
} 
interlocutores já não são os mesmos, pois são sujeitos constituídos de formações discursivas, ideológicas diferentes e que vão determinar compreensões diversas. Sendo assim, as interpretações de leituras e discursos não estão no controle nem do locutor nem do interlocutor (ORLANDI, 2007b).

No discurso do professor da SD1, ele ainda traz: “[...] eu faço perguntas pra ele, pra ele mostrar a interatividade dele em formas de sinais pra sala", evidenciando a construção do conhecimento, proporcionando a oportunidade do aluno de se expressar em língua de sinais, integrando-o na contemporaneidade e incluindo-o, tornando a aula interessante e participativa para ele e demais alunos. Essa atitude do professor corrobora com Capovilla (2000) e Quadros (2000) ao defenderem que, quando o aluno Surdo não tem o conhecimento da língua portuguesa (LP), já está em um nível escolar avançado e tem o pleno conhecimento da Língua de Sinais (LS), para que o professor trabalhe a língua escrita e oral de diferente forma, utilizando-se da escrita visual direta de sinais até que haja a alfabetização na LP, o que para os autores é considerado uma ponte metalinguística que transpõe o fosso entre LS e a escrita alfabética.

Quando o professor sai da sua "zona de conforto" e busca métodos diferenciados (sinalizar) para a participação e a avaliação da aprendizagem do aluno Surdo, ele está dando a oportunidade de o aluno fazer interpretação pessoal sem a interferência do tradutor e intérprete, ajudando-o a ter suas próprias reflexões. Nesse sentido, Quadros (2004) defende a escola bilíngue ou que os professores e todo o corpo docente tenham, ainda que pouco, o conhecimento da língua de sinais, no intuito de ajudar o aluno Surdo a se desenvolver no processo de ensino/aprendizagem da sua língua materna e da L2.

Na SD2 a professora da SRM explica: "Mas eles não conseguem ainda explicar tudo que está dentro do texto". O uso da conjunção "mas" traz a ideia de adversidade, de que haverá alguma oposição ao que foi dito anteriormente. Consideremos como diz Orlandi (1996, p. 106): “A linguagem como lugar de debate, de conflito". E “mas" pode significar muito, dar muitos sentidos, por exemplo: quando ela explica que os Surdos leem lá na sala de recursos, é porque lá se utilizam inúmeros multiletramentos, trabalhando com as imagens relacionando com a escrita, então, ao associar os dois métodos, o aluno Surdo consegue ler ou escrever o que está no enunciado, e a professora explora os conteúdos no computador através de imagens e diversos funcionamentos que acontecem ao mesmo tempo. Assim, ao dizer: "Eles leem, mas não conseguem explicar", tem o efeito de sentido de que leem mecanicamente, mas sem compreensão, ou seja, não leem, pois, para se dizer que se lê, é necessário que haja compreensão. 
É possível perceber na fala da professora da SD2 que a SRM é um espaço diferenciado da sala de aula, pois é dada ao Surdo uma oportunidade de ensino focado para aprendizagem, no qual há a presença de figuras para auxiliar na compreensão das palavras, todavia, na sala regular, não há essa dinâmica. Observa-se, assim, que o espaço da sala regular não é espaço de igualdades a todos os envolvidos, ou seja, quem possui os requisitos necessários para aprendizagem naquele espaço será atendido, caso não, será excluído.

Por exemplo, a professora diz que "dentro da sala regular são textos mais densos", ou seja, não há associação de objetos ou imagens, são textos grandes, o que, dentro da sala de aula, proporciona ao aluno a possibilidade da aprendizagem é a presença do intérprete e o uso do tablet como auxílio. Quadros (2003, p. 99) defende que o "currículo deveria estar organizado partindo de uma perspectiva visual-espacial para garantir o acesso a todos os conteúdos escolares na própria língua da criança, pois a língua oficial da escola precisaria ser, desde o princípio, a língua brasileira de sinais”.

Sendo assim, o discurso governamental de inclusão das pessoas com algum tipo de deficiência no ensino regular não condiz com a realidade, pois não favorece de forma igualitária a todos, pois o que prevalece ainda é a escola definida pela ideologia da classe dominante, a escola como Aparelho Ideológico do Estado. Segundo Althusser, todo o funcionamento da ideologia dominante está concentrado nos AIE, "a hegemonia ideológica exercida através deles é importante para se criarem as condições necessárias para reprodução das relações de produção" (ALTHUSSER, 1965 apud BRANDÃO, 2012, p. 23).

Voltamos a afirmar, então, que a LIBRAS não deve ser estudada com a mesma estrutura sintática da língua portuguesa. Por ser uma língua visual-espacial, ela possui uma estrutura sintática própria e não segue a ordem da língua oral na construção do enunciado. Essa estrutura é que faz com que o Surdo processe as ideias com base na sua percepção visual-espacial da sua realidade (STROBEL; FERNANDES, 1998).

Vejamos alguns exemplos na explicação das referidas autoras (STROBEL; FERNANDES, 1998, p. 15).

Exemplo 1: $\quad$ LIBRAS: $\quad$ EU IR CASA (verbo direcional)

Português: "Eu irei para casa"

$\underline{\text { Para }}$ - não se usa em LIBRAS, porque está incorporado ao verbo. 
Exemplo 2: $\quad$ LIBRAS: CINEMA O-P-I-A-N-O MUITO-BO@ (omissão de verbos)

Português:

“O filme O Piano é maravilhoso!”.

Exemplo 3: $\quad$ LIBRAS: $\quad$ PORQUE ISTO (expressão facial de interrogação)

Português: "Para que serve isto?"

Nesse contexto as mesmas autoras explicam que a Língua de sinais utiliza-se de classificadores (CL), formas de representar na configuração de mão de forma que "substituindo o nome que as procedem, podem vir junto de verbos de movimento e delocalização para classificar o sujeito ou o objeto que está ligado à ação do verbo" (STROBEL; FERNANDES, 1998, p. 27).

Sintetizando o exposto, Fernandes (2006) define a linguagem verbal da língua de sinais da seguinte forma: palavras sinalizadas que se diferenciam de país para país, dessa forma sofre mudanças históricas e torna-se passível de variações regionais e sociais.

Assim como nas línguas orais são encontrados os pontos de articulação dos fonemas, a LIBRAS também tem os seus pontos de articulação que são expressos por toques no espaço ou em seu próprio corpo, utilizando-se de cinco parâmetros, a saber:

CM - Configuração de Mão: é a forma que se coloca a mão para executar o sinal, podendo ser representadas pelas duas mãos a letra do alfabeto, numerais ou o próprio sinal.

PA - Ponto de Articulação: é o lugar onde se inicia a mão para a execução do sinal, podendo esse ponto ser em alguma parte do corpo, ou no espaço neutro a frente do corpo ou ao lado do corpo.

M - Movimento: é a deslocação da mão no espaço durante a execução do sinal, podendo ser sinais parados ou em movimento.

O/D - Orientação ou Direcionalidade: é a direção que o sinal será executado; EF/C - Expressão Facial ou Corporal: são feições executadas pelo rosto ou pelo corpo, dando vida ao sinal apresentado, sendo de grande importância para o surdo na sua compreensão (HONORA, 2009, p. 31).

Quadros (2004) harmoniza com Honora quando afirma que a Língua Brasileira de Sinais é uma língua visual-espacial articulada através das mãos, das expressões faciais e do corpo, é uma língua natural usada pela comunidade surda brasileira. 
A utilização das configurações e da sinalização não manuais (olhos, movimento de face, cabeça e tronco), anteriormente apontados, é expressamente importante, ou seja, prioridade na comunicação durante todo o processo de sinalização com o Surdo para que haja a interpretação e a comunicação. Essas expressões têm como função marcar sentenças interrogativas, relativas, concordância, foco, entre outros aspectos. A autora ressalta ainda que duas expressões não manuais podem acontecer simultaneamente, por exemplo, marcas de interrogação e negação (QUADROS, 2004).

Além das expressões manuais e das configurações de mão, a língua de sinais, assim como a língua oral, utiliza signos icônicos e arbitrários. Acredita-se que os sinais durante a comunicação manual são sinais parecidos com os referentes, no entanto, Strobel e Fernandes (1998) ressaltam que não é uma regra, já que em sua maioria os sinais são arbitrários, ou seja, não tem relação semelhante ao referente.

Para essas autoras, os sinais icônicos fazem alusão ao reflexo do seu significado, o que não implica na semelhança em todos os sinais, já que cada comunidade tem seus sinais/ regionalismo.

\subsection{A questão da educação bilíngue para os Surdos}

Mas que não se percam os esforços. A inauguração de uma nova etapa
histórica não significa que todos os problemas sejam resolvidos. Em seguida
se verá a realidade e funcionamento do modelo bilíngue [...] Mas nesse
processo que se inicia teremos os surdos como protagonistas e poderemos
dialogar com eles num plano de igualdade, unidos por vínculos solidários
na construção deum futuro melhor para todos.

(Carlos Sánchez)

Quando falamos de educação bilíngue, nossa mente automaticamente remete ao conceito de duas ou mais línguas sendo utilizadas pelo sujeito ou comunidade de fala. É comum pensarmos em imigrantes oriundos de outros países, até mesmo em indígenas presentes em localidades territoriais brasileiras.

Entretanto, quando falamos do sujeito Surdo, por ser brasileiro, esse raciocínio não parece tão natural, porque, na maioria das situações, imagina-se que estes devem falar a língua portuguesa como sua língua materna, uma vez que são nascidos no Brasil.

Para Quadros (2005) a definição do bilinguismo está sujeita a várias questões de ordem social, política e cultural. Segundo a autora, a proposta do bilinguismo é a mais importante para o aluno Surdo, essa proposta torna-o acessível ao conhecimento, tendo em 
vista que a língua materna natural do sujeito Surdo é a língua de sinais.

O bilinguismo é uma proposta de ensino usada por escolas que se propõe a tornar acessível à criança as duas línguas no contexto escolar. Os estudos têm apontado para essa proposta como sendo mais adequada para o ensino de crianças Surdas, tendo em vista que considera a língua de sinais como língua natural e parte desse pressuposto para o ensino da língua escrita (QUADROS, 1997, p. 27).

O Brasil tem a intenção de "subtrair", não no sentido negativo, mas no sentido de não levar ao uso a outra língua, então subtrai ao invés de somar/adicionar outras línguas, ou mesmo incentiva o uso de outras línguas com qualidade dentro dos espaços escolares junto à língua portuguesa, o que leva à ideia de que o uso de outra língua poderá apagar a língua “oficial” brasileira (QUADROS, 2005).

Apoderar-se de outras línguas não simboliza uma ameaça, nesse sentido Quadros (2005) abre um leque de conhecimentos linguísticos em diferentes contextos. A questão da diferença, o ser Surdo, dificulta o reconhecimento de que estes são sujeitos bilíngues, ou seja, nasceram no Brasil, portanto devem falar em língua de sinais como sua língua materna (L1) e escrever em português (L2).

No entanto Quadros (2005, p. 28) lista uma série de fatores que dificulta tal aceitação por parte da sociedade de que os Surdos são bilíngues:

a) A modalidade das línguas: visual-espacial e oral-auditiva.

b) Surdos filhos de pais ouvintes: os pais não conhecem a língua de sinais brasileira.

c) O contexto de aquisição da língua de sinais: um contexto atípico, uma vez que a língua é adquirida tardiamente, mas, mesmo assim tem status de L1.

d) A língua portuguesa representa uma ameaça para os surdos.

e) A idealização institucional de status bilíngue para os surdos: as políticas públicas determinam que os surdos "devem" aprender português.

f) Os surdos querem aprender na língua de sinais.

g) Revisão do status do português pelos próprios surdos: reconstrução de um significado social a partir dos próprios surdos.

Para a autora, ao se pensar no bilinguismo na educação dos Surdos, faz-se necessário levar em consideração os elementos acima representados.

Considerando que a aquisição de qualquer língua, quando em interação com outro falante, caracteriza-se pela aquisição da linguagem em sua plenitude, assim também é o Surdo quando está diante de outro Surdo que domina a língua de sinais, a nostalgia encontrada em uma conversa de Surdo com Surdo demonstra a identidade do eu encontrada (QUADROS, 
2005).

Quadros (1997, p. 30) explica as vantagens para o aluno Surdo da proposta bilíngue na escola:

\begin{abstract}
A presença de Surdos adultos apresenta grandes vantagens dentro de uma proposta bilíngue. Primeiro, a criança, tão logo tenha entrado na escola, é recebida por um membro que pertence à sua comunidade cultural, social e linguística; assim, ela começa a ter oportunidade de criar a sua identidade. Segundo, essa criança começa a adquirir a sua língua natural. Tais vantagens são imprescindíveis para o sucesso da proposta bilíngüe [...] assim, tornarse-á possível o ensino de uma segunda língua, caso contrário, a criança Surda não terá chances de apresentar um domínio razoável da língua portuguesa.
\end{abstract}

Para Perlin (1998) as crianças Surdas estão tendo acesso a sua língua materna (L1) muito tarde, as escolas não proporcionam o encontro de adultos Surdos com as crianças Surdas, esse encontro só está acontecendo na adolescência e por acaso, e a falta desse contato dificulta as descobertas de mundo.

É uma identidade subordinada com o semelhante Surdo, como muitos Surdos narram. Ela se parece a um imã para a questão de identidade cruzadas. Esse fato é citado pelos Surdos e particularmente sinalizado por uma mulher Surda de 25 anos: aquilo no momento de meu encontro com os outros surdos era o igual que eu queria, tinha a comunicação que eu queria. Aquilo que identificavam eles identificava a mim também e fazia ser eu mesma, igual. O encontro Surdo-Surdo é essencial para a construção da identidade Surda, é como abrir o baú que guarda os adornos que faltam ao personagem (PERLIN, 1998, p. 54).

Compreendida a importância do encontro Surdos/Surdos, os pais ouvintes precisam descobrir esse mundo da linguagem visual-espacial e apoderar-se da língua de sinais brasileira, penetrando na comunidade surda e na sua cultura, ajudando na concretização desse viés bilíngue (QUADROS, 2005).

Segundo Cummins (2003 apud Quadros, 2005) quando os pais ouvintes entendem a importância de seus filhos conviverem com outros Surdos adultos, estão ajudando a consolidar o processo de aprendizagem dos filhos. Esse processo deve acontecer o quanto antes, quando a criança ainda é muito pequena. Esse círculo de amizade acontecerá em uma comunidade surda que usa a língua de sinais. Quando acontece esse processo, a criança está preparada para ir à escola e, amparada pelo intérprete da LIBRAS, conseguirá aprender a língua portuguesa como segunda língua.

Quando falamos de educação bilíngue para os sujeitos Surdos no Brasil, autores como 
Ferreira-Brito (1993), Quadros (1997), Skliar (1997,1998) e Perlin (1998) argumentam que os Surdos têm formado grupos sociais com identidade e cultura, o que tem fortalecido a luta para a formação das escolas bilíngues para Surdos.

Para Fernandes (2006) a atual educação dos Surdos está sempre em desvantagem quando se fala das relações de saberes em sala de aula, uma vez que as práticas linguísticas estão sempre no campo do desconhecido, da ignorância, do erro, do eternizado "nãosaber" nas práticas linguísticas.

Embora não pareça, Quadros (1997) ressalta que houve grandes avanços para que a proposta do bilinguismo seja colocada em prática. Segundo a autora, o reconhecimento da língua de sinais e o direito dos Surdos de tê-la como sua primeira língua, e o uso dos sinais nas escolas é um marco para a comunidade surda, conforme a Lei $\mathrm{n}^{\circ} 13.005$, de 25 de junho de 2014, que aprova o Plano Nacional da Educação - PNE, art. 11, item 4.7.

Garantir a oferta de educação bilíngue, em Língua Brasileira de Sinais LIBRAS como primeira língua e na modalidade escrita da Língua Portuguesa como segunda língua, aos(às) alunos(as) surdos(as) e com deficiência auditiva, de 0 (zero) a 17 (dezessete) anos, em escolas e classes bilíngues e em escolas inclusivas, nos termos do art. 22 do Decreto ${ }^{\circ} 5.626$, de 22 de dezembro de 2005 , e dos arts. 24 e 30 da Convenção sobre os Direitos das Pessoas com Deficiência, bem como a adoção do Sistema Braille de leitura para cegos e surdos-cegos.

De acordo com Fernandes (2008) o bilinguismo é um fato novo para os profissionais da educação; apenas nas últimas décadas é que o tema passou a ser incorporado nas políticas públicas educacionais, depois de lutas e movimentos sociais e a incorporação de pesquisas na área linguística. A questão é que o fato de a LIBRAS ser uma língua visual-espacial, em relação à língua portuguesa, determina uma reestruturação na questão da inclusão do sujeito Surdo nas escolas brasileiras (QUADROS, 2005).

Considerando que essa reestruturação vai muito mais além, para a criação de escolas bilíngues, requer-se, além de mudanças na arquitetura escolar, que haja mudanças também "nos espaços, nas formas de interação, nas formações de professores bilíngues, de professores Surdos e de intérpretes de língua de sinais" (QUADROS, 2005, p. 34).

Dentro dessas questões da educação de Surdos, o currículo deve ser organizado em uma perspectiva visual-espacial que garanta aos Surdos acesso a todos os conteúdos escolares na língua da criança, a LIBRAS.

Para Peixoto (2006, p. 207) o reconhecimento da condição bilíngue do Surdo é apenas o começo de um longo caminho de descobertas e desafios: 
O acolhimento necessário e imprescindível da língua de sinais, como primeira língua do surdo e língua escolar, devolve ao surdo a esperança, ao mesmo tempo em que nos convoca a pensar sobre os processos e práticas construídos - agora - à luz dessa nova condição. A subjetividade do surdo e todos os processos relacionados a ela ganham novas nuanças, delineando-se talvez de forma diferente ao que supúnhamos acontecer quando a língua de sinais era - radicalmente - negada e as práticas pedagógicas eram, quase exclusivamente, mediadas pela língua oral.

Quadros (2005) afirma, ainda, que a educação na perspectiva bilíngue toma formas que transcendem as questões linguísticas. Tanto na língua de sinais quanto na língua portuguesa, essa educação está situada no contexto e na garantia de acesso e permanência na escola definida pelos próprios movimentos surdos, a fim de consolidar a educação do sujeito Surdo em um país que se compreende "equivocadamente monolíngue”.

\subsection{Letramento no contexto do aluno Surdo}

As línguas são naturais e utilizadas por toda a sociedade em seu convívio. Sejam estas orais ou gestuais, abordamos qualquer conceito, podendo ser concreto ou abstrato, racional ou emocional, e nesse contexto sempre transmitiremos algo por serem línguas estruturadas e organizadas (QUADROS, 2006).

Entre os muitos desafios vivenciados pelo Surdo, a dificuldade de expressar-se através da escrita na língua portuguesa é um obstáculo a ser vencido, visto que a sua língua materna é construída por sinais e lugares no espaço, o que reforça a necessidade da apropriação da escrita dos sinais. Quadros (2000) explica que a criança utiliza-se da oportunidade de expressar suas ideias, pensamentos e experiências de mundo através dos sinais, traduz momentos fundamentais no processo de aquisição da leitura e escrita: "[...] no processo de aquisição do português, as crianças surdas apresentarão um sistema que não mais representa a primeira língua, mas ainda não representa a língua alvo” (QUADROS, 2006, p. 34).

Mesmo com tentativas e ações no sentido de se adequar às demandas sociais exigidas, podemos perceber os efeitos de sentido na discursividade dos agentes letradores quando o assunto está relacionado à leitura/escrita do aluno Surdo cuja abordagem a realidade escolar não contempla.

SD3 - Para mim, no meu entendimento, era natural o alunojá saber LIBRAS e o correspondente na língua escrita e língua portuguesa, até eu descobrir que ele (o meu aluno) não sabia ler. Nossa! Eu fui pra casa tão mal aquele dia... Fiquei pensando, mas 
como ele conversa por WhatsApp? (P. 3, sala regular).

SD4 - No caso do menino, eu vou ser bem sincera, talvez eu seja errada, tem momentos que olho pra ele, e ele está "boiando", que ele não está entendendo muita coisa, pra mim ele tinha que ser alfabetizado em LIBRAS desde o a, b, c... porque ele não conhece o alfabeto ainda, tanto que ele fica sempre olhando o banner que tem na sala. Hoje eu penso que deveria ser mais investido na língua dele L1, pra começar a língua portuguesa. É o que eu entendo, porque ele não dá conta com a língua portuguesa (P. 5, sala regular).

SD5 - Já é o meu segundo ano com esse mesmo aluno, a LIBRAS dele é perfeita, o problema é só o português mesmo, se for palavras soltas, ele lê, mas um texto contextualizado dentro da norma portuguesa ele não consegue (TILS 3).

SD6 - Iniciamos com ela aquele trabalho que é feito na educação infantil de alto, baixo, esses conceitos de cores, depois a gente começou a colocar as letras, todos os dias a gente escreve o nome da escola e o nome dela. A princípio a coordenação dela era bem grande, ela escrevia bem grande o tamanho da letrinha, depois a auxiliar passava os pontilhados para a aluna fazer, a auxiliar faz a letra no sinal e daí mostra para a aluna, pra daí ela estar fazendo essa ligação. Eu estou indo passo a passo com ela, um trabalho que isso daí se fosse com uma criança que ouve, digamos assim, deveria ter sido trabalhado lá no pré (P. 4, sala regular).

SD7 - Aí eu vou deixar uma coisa clara para você! Quando ela iniciou conosco, a mãe não permitiu o uso da língua de sinais por conta de laudos médicos. A aluna não tinha a língua de sinais ainda porque eles não deixavam, porque os médicos achavam que talvez ela iria aprender. Quando ela veio para nós aqui, que a gente fez todos os encaminhamentos, que daí ela passou a tratar aqui em Sinop, que daí ela foi para o posto, a primeira coisa que os médicos falaram foi, tem que entrar com a língua de sinais (COORDENADORA).

Para o aluno Surdo apropriar-se da escrita na língua portuguesa, de acordo com Fernandes (2003) dependerá do conhecimento deste em língua de sinais e da metodologia do professor.

[...] a linguagem escrita, essa possibilidade pode ser assegurada a todas as pessoas surdas, visto que a perda auditiva em nada interfere na apropriação da modalidade gráfico-visual da língua. Desde que haja uma base linguística assegurada pelo acesso à língua de sinais como língua materna na infância, substituindo a oralidade em conteúdo e função simbólica, não haverá prejuízos ao aprendizado da escrita pelas crianças surdas. No entanto, a possibilidade do aprendizado da escrita está vinculada à forma como esse processo será organizado pela escola, considerando a necessidade da adoção de metodologias específicas de ensino, com professores especializados para este fim, tal qual ocorre em situações de aprendizado de línguas estrangeiras. Essa comparação se justifica, tendo em vista que a criança surda não aprenderá o português como língua materna, mas como segunda língua. $\mathrm{Ou}$ seja, não podemos alfabetizar uma criança surda, se considerarmos a natureza do aprendizado envolvida nesse processo (FERNANDES, 2003, p. 4). 
A questão da alfabetização-analfabetismo é uma posição construída historicamente que produz diferença, segundo Silva (2017, p. 26): “Os sentidos produzidos em cada termo da dicotomia se determinam". Por exemplo, observamos na SD3 que a professora não sabia que seu aluno Surdo não sabia ler. Porque o seu aluno Surdo tem o domínio da Língua de sinais, pensou ela que automaticamente ele teria também o português, conforme Fernandes descreve acima, mas a autora coloca ainda uma condição para que ocorra esse aprendizado: "a possibilidade do aprendizado da escrita está vinculada à forma como esse processo será organizado pela escola, considerando a necessidade da adoção de metodologias específicas de ensino, com professores especializados para este fim”.

No entanto, não foi isso o que aconteceu com esse aluno. Podemos perceber isso quando ela diz: “(o meu aluno) não sabia ler”, ou seja, Silva (2017, p. 28) explica que há um já-lá-dito do analfabetismo - "condição, estado de analfabeto" - que nega o sentido da alfabetização - "ação de ensinar a ler e a escrever" -, o que a autora chama de "memória discursiva como condição de possibilidade de funcionamento da escolarização", isto é, o sujeito é atravessado por uma divisão opaca ambígua da linguagem.

Capovilla \& Capovilla (2004) explicam que há uma dificuldade terminante na aquisição da leitura e escrita alfabéticas. Para os autores, essa dificuldade reside no fato de o desenvolvimento cognitivo e linguístico pleno possibilitar à criança usar sua LS (como L1) como metalinguagem para a aquisição da leitura e da escrita, porém, essas duas habilidades são introduzidas, na vida do aluno, por meio da LP. Por meio de estudos, os autores concluíram que há tipos de inadequações ao ler e escrever que a criança Surda comete:

Tal análise revela que a escrita mapeia o processamento de informação na língua primária, que é a fala para a criança ouvinte e a LS para a criança surda. [...] No entanto, como a escrita alfabética mapeia os sons da fala, os erros da criança ouvinte são muito menos graves do que os da surda. [...] Como a criança surda não tem acesso aos sons da fala, esses não servem de auxílio à escrita (CAPOVILLA \&CAPOVILLA, 2004, p. 35).

O fato de o aluno não saber ler e escrever, talvez como a professora deseje ou pensa ser o adequado na estrutura gramatical da língua portuguesa, a fez refletir sobre a questão de o aluno utilizar o WhatsApp para comunicar-se com os demais, "mas como ele conversa por WhatsApp?". Instaura-se aí o conflito entre o letrado e o iletrado, analfabeto ou alfabetizado? Para Santos (2014) o uso desses meios de relacionamentos, como Facebook, blogs, incluindo o WhatsApp ${ }^{7}$, é uma ferramenta poderosa na mão do educador se usados com

\footnotetext{
${ }^{7}$ Acréscimo da pesquisadora.
} 
fins educativos, pois o processo de ensino/aprendizagem pode ocorrer de forma criativa e interessante.

Essa professora tem o discurso inscrito na ideologia do pré-construído de que quem está frequentando a escola no final da primeira fase do ensino fundamental já sabe ler e escrever a língua materna, o português. A limitação dela talvez se deva ao fato de não ter as mesmas condições de produção dos alunos Surdos. Outra marca que encontramos está no discurso dela quando diz: "Até eu descobrir que ele (o meu aluno) não sabia ler". Esse "até" na frase demonstra que houve um tempo para que ela descobrisse que seu aluno não lia e nem escrevia, sendo assim entendemos que não há espaço em sua aula para que os alunos se exponham, para que haja troca de papéis, reversibilidade. Pois, se fosse esse o caso, a professora já teria notado as peculiaridades do aluno.

O discurso da professora da SD4 nos transmite a imagem que ela tem do aluno Surdo, de que ele demonstra pouco ou nenhum conhecimento do uso da LP e da LIBRAS. A professora acredita que o aluno encontra-se nessa situação em função do passado vivido por ele, ou seja, a família e a escola precisavam ter agido de maneira a proporcionar a alfabetização do aluno Surdo na L1 e depois na L2, conforme indicado por estudiosos, a saber: "tinha que ser alfabetizado em LIBRAS", "deveria ser mais investido na língua dele, L1”. Estas são construções parafrásticas que funcionam inscritas na imagem de que o aluno Surdo apresenta dificuldades na aprendizagem por não saber LIBRAS e, portanto isso dificulta a aprendizagem do português, corroborando com Quadros (2004) quando ela diz que, para o Surdo aprender a segunda língua (L2), no caso o português, ele deve ter o domínio completo ou parcial da sua língua materna, ou seja, a Língua de Sinais.

$\mathrm{Na}$ SD5 a intérprete explica que o aluno tem domínio da LIBRAS, mas não do português. Ao usar o advérbio, com o sentido de somente, pretende reduzir o problema, dizendo que não há outro problema a não ser o português. Quer dizer que, em qualquer outra atividade exigida na escola, o aluno consegue desenvolver, desde que não envolva a língua portuguesa. Ao relatar: "o problema é só o português mesmo", e afirmar: "a LIBRAS dele é perfeita", o uso do advérbio "só" reforça que não existem outros problemas, somente o "português", reforçado mais uma vez pelo advérbio "mesmo", ou seja, o que se quer dizer é que não há outros problemas, somente o da língua portuguesa.

Na perspectiva da AD, apresentar esse "só" é uma forma de silenciamento em que a escolha de palavras específicas ocorre a fim de não se dizer outras que podem ser interpretadas de forma preconceituosa (ORLANDI, 2007a). Essa ação apresenta-se como metaforização, ou seja, quando a intérprete diz "o problema é só o português mesmo", poderia 
ser substituída por "o problema é que não sabe o português". O uso de negativas, pode se figurar na ideia de que o Surdo tenha problemas adjacentes à própria situação vivida por ele naturalmente, isto é, que, além de possuir o comprometimento na audição, encontra-se com dificuldade de aprender o português, ou seja, o processo de inclusão acontece no processo escolar pela colocação do aluno Surdo junto com os ouvintes, no entanto, percebe-se nesse dizer o processo de exclusão do aluno Surdo com seus direitos e deveres no fazer pedagógico. Ocorrendo assim a in/exclusão, pois de acordo com Lopes e Menezes (2010, p. 10):

Aqueles que não possuem experiências com outros surdos não desenvolvem marcas capazes de os identificarem com surdos e, neste caso, a marca acaba sendo a da deficiência e da anormalidade. Lopes e Veiga-Neto (2006) salientam que, na relação com o ouvinte, os sujeitos surdos foram ensinados a olharem-se e a narrarem-se como deficientes auditivos. A marca da deficiência determinou e tem determinado, até nossos dias, a submissão dos surdos aos ouvintes, sendo que estes representam a normalidade e a referência a ser seguida. Nesse jogo de imposição de marcadores que acabam definindo a alteridade surda, a diferença destes sujeitos passa a ser vista como algo indesejado no corpo. São sentimentos de discriminação, de compaixão, de dificuldade, de ameaça e de anormalidade que atravessam as subjetivadas surdas quando esses sujeitos não possuem o direito de se ver como surdos entre pares surdos.

A inclusão pode ser pensada de múltiplas maneiras e, de acordo com Lopes e Menezes (2010, p. 5, grifo da autora), deveria ser pensada com o sentido de acolhimento ético:

Ao usarmos a palavra "inclusão" não estamos acionando significados
universais e transcendentais, tão pouco estamos acionando elos entre a
experiência e a palavra. Estamos mergulhados em jogos de linguagem, que
envolvidos em práticas sociais, determinam significações distintas para as
palavras. No jogo onde muitos sujeitos surdos militantes pelo
reconhecimento da diferença surda estão mergulhados, a inclusão toma o
sentido de acolhimento ético.

Ao trabalhar a inclusão como relação de ética, Lopes e Menezes (2010, p. 7) afirmam: "Ética nas relações com a diferença determina as condições do acolhimento. Acolhimento sem distinção de raça, cultura, etnia, classe social, etc.” Levinas (1997) afirma que a ética é o próprio humano; é a capacidade humana de dar em relação a si, prioridade ao outro.

A metaforização do "é só aprender o português" rememora o autoritarismo do dizer escolar da necessidade da aprendizagem da língua portuguesa como uma norma-padrão e que "todos" deveriam segui-la. O sujeito-Surdo é incluso no processo escolar pela lei, mas, sem considerar as adequações necessárias, a sua língua materna, e que são garantidas na mesma lei, ou seja, segue-se toda uma estrutura já posta por força de lei que é inclusão, ou seja, a in/exclusão. 
De acordo com Pêcheux (1990) apud Orlandi (2003) o efeito metafórico está configurado em um fenômeno semântico apresentado por uma substituição contextual, originando um deslize de sentido. Para a autora, o gesto de interpretação do analista, ao relatar e interpretar um discurso, articula com a paráfrase e a metáfora como característica do funcionamento da discursividade:

A paráfrase e a metáfora explicitam-se, pois, enquanto procedimentos de análise. Esta é, para mim, uma marca da especificidade da análise de discurso: ela introduz uma noção não linguística de paráfrase e uma noção de metáfora que não deriva da retórica, ou dos estudos literárias, assim como uma noção de "memória" que tem suas determinações que não são psicológicas, cronológicas, etc. A relação entre essas noções e o modo de procedimento da análise de discurso, ligando o que é estabilizado e o que é sujeito a equívoco, no movimento da descrição e da interpretação vai marcar profundamente os estudos da linguagem (ORLANDI, 2003, p. 5).

Para Orlandi (2012), ao considerar que sujeito e sentidos se constituem ao mesmo tempo, tende-se a pensar que, por outro lado, os sentidos e os sujeitos não se coincidem entre si. Metáfora, inexatidão, não transparência, movimento, não acabamento.

Voltando aos recortes, observamos na SD6 que a professora apresenta uma ideologia de que a atividade com aluno Surdo é bem trabalhosa e de que não é responsabilidade dela, pois deveria ter sido feito na pré-escola. O uso da expressão "digamos assim" demonstra que há o silenciamento do desconforto que sente ao ter que trabalhar com o Surdo, pois se preocupa com o termo que vai utilizar ao se referir a ele, para não ser interpretada como preconceituosa, da mesma forma que ocorre na SD5.

Com relação à inclusão, faz-se pertinente a fala de Dias (2008) de que o homem tenta justificar o injustificável, ou a sua repulsa ao diferente, ao outro, àquele que não se faz presente dentro das normas estabelecidas pelo poder.

Esse outro insuportável tem, portanto, que ser regulado, enquadrado. Ele precisa ser adaptado a um modo de vida em sociedade, seja ela qual for, ele precisa ser incluído, educado, disciplinado. E isso se faz pelo modo como certa cultura vai envolvendo o sujeito em hábitos que se naturalizam no seu dia-a-dia (DIAS, 2008, p. 4).

Ao analisarmos o discurso da SD7, quando a coordenadora diz: "Vou deixar uma coisa clara para você", apresentamos mais uma vez aqui o não dito, de que os cuidados com as palavras utilizadas na entrevista, ou que alguns discursos não estão claramente 
apresentados, talvez por haver certo cuidado em expor os seus pensamentos, deixando o silêncio falar.

O não dito, nesse sentido, faz parte do discurso que não é palavra. Devido à linguagem ser dialética, traz essa possibilidade do sujeito silenciar em dado momento do discurso e revelar-se em outros. Com esse jogo entre o dito e o não dito, o sujeito obriga-se a falar, surgindo, assim, a possibilidade do movimento dos sentidos, estabelecidos nas formações discursivas. Para Orlandi (2015a, p. 80), o não dito diz respeito às diversas facetas da linguagem, perpassa e ultrapassa todo o dito, “[...] é subsidiário ao dito, de alguma forma, o complementa, acrescenta-se". Ainda para a autora, essas FD são entendidas como “[...] diferentes regiões que recortam o interdiscurso e que refletem as diferenças ideológicas, o modo como as posições dos sujeitos, seus lugares sociais aí representados, constituem sentidos diferentes" (ORLANDI, 2007a, p. 25).

Outra marca apresentada na SD7 pela coordenadora é a que chamamos de "bairrismo", no sentido de que a coordenadora parece valorizar o seu município, o seu povo, porque diz que a aluna não sabia LIBRAS por causa dos médicos do lugar onde a aluna morava. Quando começou a ser tratada em Sinop, os médicos pediram para que a aluna aprendesse Libras e corroboraram a ideia da professora de que aprender LIBRAS iria facilitar a vida dela.

Percebemos, dessa forma, que a professora considera os médicos de Sinop melhores e mais competentes do que os de outros lugares, e, provavelmente, isso se deva ao fato de que consideramos que o que pensamos é o que é certo, e, como os médicos de Sinop foram ao encontro das ideias da professora, a ação destes foi defendida e apoiada por ela.

Cabe aqui a reflexão de Silva em relação a essa inclusão/excludente dentro da escola, “[...] a exclusão é internalizada no sentido de que o aluno permanece na instituição escolar mesmo sem aprendizagem" (FREITAS, 1992 apud SILVA, 2017, p. 3).

A questão aqui é a constituição da subjetividade Surda, a identidade Surda vai se dissipando quando a língua do Surdo vai se misturando, se tornando híbrido com o português, porque o ouvinte, ao tentar ser o interlocutor, tende a misturar as duas línguas, e, sendo a língua portuguesa a majoritária, a língua de sinais tende a se diluir (GOÉS, 1999 apud QUADROS, 2003), o que novamente apresenta a in/exclusão discutida por Lopes e Menezes (2010).

Outra questão que a coordenadora apresenta é de que a LIBRAS foi omitida pela família ao aluno. Isso nos remete novamente ao dizer de Lopes e Veiga-Neto (2006 apud LOPES e MENEZES, 2010, p. 10) de que "a marca da deficiência determinou e tem determinado, até os nossos dias, a submissão dos Surdos aos ouvintes, sendo que estes 
representam a normalidade e a referência a ser seguida". Assim, a família pode ter optado pela tentativa de buscar que seu filho falasse para que não ficasse submisso aos ouvintes, o que mostra também a relação de força e poder sobre a fala e a impossibilidade da fala, conforme o pré-construído da sociedade, observado na história da educação do Surdo. 


\section{LETRAMENTO, MULTILETRAMENTOS E TECNOLOGIA ASSISTIVA}

Neste capítulo explanaremos sobre algumas teorias voltadas aos conceitos de letramento, multiletramentos e tecnologia assistiva (TA), e suas implicações na metodologia educacional. Buscamos, para essa discussão teórica, Magda Soares (1998, 2004, 2006, 2008), Leda Tfouni (2010), Emília Ferreiro (1996,1999), Roxane Rojo (1998, 2009), Teófilo Galvão (2009), Sandra Straub (2009), entre outros.

\subsection{Letramento e multiletramentos}

O termo letramento, definido por alguns estudiosos, conceitua-se em rupturas na aprendizagem dos códigos ou signos e o seu uso; no entanto, para a educadora e pesquisadora Emília Ferreiro (1999) essa ruptura não existe.

Letramento, segundo Soares (1998) é o estado do sujeito que sabe ler e escrever e que faz o uso assíduo da leitura e da escrita, alterando o seu lugar social e na sua comunidade cultural quando se torna um sujeito letrado. Para Tfouni (2010, p. 12) letramento "focaliza os aspectos socio-históricos da aquisição da escrita. [...] tem por objetivo investigar não somente quem é alfabetizado, mas também quem não é alfabetizado, e, nesse sentido, desliga-se de verificar o individual e centraliza-se no social".

A palavra Letramento surgiu no Brasil pela tradução de Literacy, que, segundo Magda Soares (1998, p. 170) o sufixo "cy" significa qualidade, estado, condição ou fato de ser, então, para a autora, Literacy seria "estado ou condição que assume aquele que aprende a ler e escrever”. Ainda para Soares (2004) letramento assinala atributos dados aos que dominam as habilidades de leitura e escrita e sabem usá-las nas diferentes circunstâncias sócio comunicativas em que são necessárias, contrapondo-se à alfabetização, pois, embora alfabetizadas, algumas pessoas não dominam a leitura e a escrita diante de práticas sociais que envolvem a língua escrita.

A adjacência letramento surgiu na contemporaneidade para complementar o conceito de alfabetização. Alfabetização-analfabetismo, definido por Silva (2015, p. 26, grifo do autor) como:

[...] uma oposição historicamente construída que produz uma diferença como efeito de sentido - constitutiva e constituinte do processo de escolarização. Os sentidos produzidos em cada termo da dicotomia se determinam: há um já-lá-dito do analfabetismo - "condição, estado de 
analfabeto" - que nega o sentido da alfabetização - "ação de ensinar a ler e a escrever" - , inscrito na memória discursiva como condição de possiblidade de funcionamento da escolarização, da definição e estruturação da natureza e função social da escola no Brasil. O sujeito da escolarização é uma unidade submetida a uma divisão que é atravessada pela opacidade e ambiguidade da linguagem.

Dessa forma, o letramento veio para ser incorporado e dar uma nova forma de acompanhar o desenvolvimento social, cultural e econômico do país.

Para Tfouni (2010) escrita, alfabetização e letramento, embora ligados entre si, têm uma relação de independência; se diferem quanto ao campo de atuação e à própria essência do que seja cada seguimento. Segundo ela, a escrita é um produto cultural; alfabetização e letramento são processos da aquisição de um sistema escrito.

[...] a falta, em nossa língua, de uma palavra que pudesse ser usada para designar esse processo de estar exposto aos usos sociais da escrita, sem, no entanto, saber ler nem escrever. Foi dessa constatação que surgiu o neologismo letramento (TFOUNI, 2010, p. 10).

No Brasil, a partir do século XX, iniciaram-se as avaliações censitárias para saber o nível de analfabetismo, sendo que o simples fato de assinar o próprio nome dava à pessoa a condição de alfabetizada. No ano de 1950, com a participação da Organização das Nações Unidas para a Educação, a Ciência e a Cultura - UNESCO, é que mudaram esse conceito, então, para que alguém fosse considerado alfabetizado, fazia-se necessário saber escrever um pequeno trecho de um texto em qualquer idioma (FERREIRO, 1999).

Mas o mundo está globalizado e, com a chegada das tecnologias, fez-se necessário repensar em novos meios de leitura e escrita, onde somente o decifrar dos códigos não poderia mais considerar uma pessoa alfabetizada.

Conhecer a "mecânica" ou o funcionamento da escrita alfabética para ler e escrever significa, principalmente, perceber as relações bastante complexas que se estabelecem entre os sons da fala (fonemas) e as letras da escrita (grafema), o que envolve o despertar de uma consciência fonológica da linguagem: perceber sons, como se separam e se juntam em novas palavras etc. (ROJO, 2009, p. 61, grifo do autor).

Quando falamos de processo de representação, Emília Ferreiro (1999) afirma, ainda, que a escrita não deve ser um código de transcrição gráfica de unidades sonoras, mas um sistema de representação que acompanha e evolui historicamente, e que respeita o processo de simbolização. Quando a criança percebe o que a escrita representa para ela, quando esse 
processo faz sentido, inicia-se então a aquisição desses signos e símbolos que é a leitura e a escrita.

Para Ferreiro (1999, p. 23) a alfabetização inicia-se para alguns fora do ambiente escolar e, para outros, somente quando adentra a escola e entra em contato com a leitura e escrita:

Há crianças que chegam à escola sabendo que a escrita serve para escrever coisas inteligentes, divertidas ou importantes. Essas são as que terminam de alfabetizar-se na escola, mas começaram a alfabetizar muito antes, através da possibilidade de entrar em contato, de interagir com a língua escrita. Há outras crianças que necessitam da escola para apropriar-se da escrita.

No tocante à alfabetização, Tfouni (2010) diz que ela pode ser compreendida de duas formas: processo de aquisição individual de habilidades para a leitura e escrita ou como processo de representação de objetos de naturezas diversas.

A primeira perspectiva vê a alfabetização como algo que chega a um fim, além de estar intimamente ligada à instrução formal e às práticas escolares, portanto é difícil lidar com essas variáveis separadamente, pois a escola ainda é vista como o lugar onde se alfabetiza.

No entanto, Willian Teale (1982 apud TFOUNI, 2010) procura separar o processo de alfabetização da escolarização quando nos diz que a alfabetização não é meramente uma habilidade usada para produzir, decodificar e compreender a escrita, pois, quando as crianças são alfabetizadas, elas usam a leitura e a escrita para executar as práticas que constituem sua cultura.

Sob esse ponto de vista, a alfabetização não se completa nunca, porque a sociedade vive em contínua mudança e a atualização individual é imprescindível para acompanhá-la. Sendo assim, é melhor se falar em graus ou níveis de alfabetização, pois o desempenho do indivíduo dentro dessa escala é determinado, sobretudo, pelas práticas sociais da qual participa (TFOUNI, 2010).

Contudo avaliar o grau ou nível de alfabetização seria o mais sensato entre os conceitos aqui estabelecidos: um movimento do indivíduo dentro de uma escala de desempenho determinado pelas práticas sociais nas quais ele está inserido.

Dessa forma, Ferreiro (1996) argumenta que não há dúvidas com relação à alfabetização da criança no ambiente social, no entanto as crianças não dominam essas informações com facilidade. Para a referida autora, a criança necessita de um processo considerado, por ela mesma, de extrema importância, a saber: 
a) Restaurar a língua escrita a sua posição de objeto social.

b) $\mathrm{Na}$ fase inicial (desde a pré-escola), aceitar que todas as crianças produzam e interpretem a escrita, cada qual no seu próprio tempo.

c) Aprovar e instigar que a criança tenha contato com a escrita, em diversos contextos.

d) Possibilitar o acesso á escrita do nome próprio o quanto antes.

e) Evitar as correções ortográficas (FERREIRO, 1996, p. 44).

Para Pierre Giroux (1983 apud TFOUNI, 2010) a relação entre letramento e escolarização se consuma dentro da escola, mesmo que o letramento ocorra inicialmente no seio familiar, ou seja, cabe à escola o ato de alfabetizar. Já Ferreiro (1987, p. 9) argumenta que não podemos nos esquecer de que "a natureza do objeto de conhecimento envolve essa aprendizagem".

Segundo Tfouni (2010) o termo "iletrado" não é usado como antítese de "letrado", pois não existe letramento "grau zero" nas sociedades modernas; aponta que existem "graus de letramento", da mesma forma a autora sugere que seja esclarecida a confusão que se faz entre os termos "não alfabetizado" e "iletrado", tratando da perspectiva etnocêntrica, que diz que somente com a aquisição da escrita as pessoas conseguem desenvolver raciocínio lógicodedutivo, capacidade para fazer inferências, parasolução de problemas, como um deslize preconceituoso.

Devemos pensar em derrubar a perspectiva de que somente com a aquisição da escrita as pessoas desenvolvam sua capacidade lógico-dedutiva, denominada etnocêntrica, considerando a alfabetização e o letramento como processos interligados e continuum, evitando as classificações de letrado e iletrado ou alfabetizado e não alfabetizado (TFOUNI, 2010).

Dessa forma, a sociedade industrial moderna, juntamente com o desenvolvimento tecnológico, define as pessoas não alfabetizadas como pessoas não letradas, alienando-as, deixando-as de lado, fazendo-as abrirem mão de sua cultura frente à relação de poder, dominação, participação e resistência. Segundo Tfouni (2010) letramento não é só leitura e escrita associada à alfabetização, mas sim o fato de que existem questões históricas e sociais que influenciam nesse letramento.

Diante do exposto, concordamos com Kleiman (1995) quando afirma que o letramento ideológico produz, enquanto práticas discursivas, uma dicotomia de superioridade, diferente do não letrado, que produz efeitos de sentido de inferioridade.

Durante uma pesquisa de Lodi (2004) com alunos Surdos, esta concluiu que as dificuldades de leitura e escrita da língua portuguesa por eles advêm da falta da educação 
bilíngue, ou seja, a criança não teve acesso à língua de sinais e do conhecimento de mundo, desse modo a pesquisadora defende:

\begin{abstract}
A necessidade dos surdos serem imersos em situações de leitura significativas, que envolvam temas diversos desenvolvidos em gêneros discursivos variados. Deve se considerar que a restrição quanto aos conhecimentos de mundo e de quanto às interações dialógicas com os diferentes temas são decorrentes da forma pela qual os sujeitos têm acesso a eles, ou seja, por meio de interação face a face estabelecida por intermédio da linguagem oral $-\mathrm{e}$, portanto, de difícil acesso a eles - (LODI, 2004, p. 242).
\end{abstract}

Nesse caso, o letramento para a criança Surda, no processo de aprendizagem, somente fará sentido se esta conhecer a sua língua materna, a língua de sinais brasileira (L1). Quando a criança aprender essa língua, obterá a alfabetização na segunda língua, a língua portuguesa (L2), dessa forma caracteriza-se o contexto bilíngue do sujeito Surdo, o que podemos observar no Recorte a seguirdos efeitos de sentido provocados na discursividade das professoras da sala regular.

SD8 - A aluna foi alfabetizada desde pequenininha, e conversei com a mãe dela pra participar do curso junto comigo, procurar aprender LIBRAS pra ajudar na aprendizagem da filha, e ela fez, participou, então isso facilitou muito pra mim como professora. A menina é bastante inteligente, eu até costumo falar que se ela ouvisse, ela seria a primeira da sala, as notas dela sempre são altas é nove, dez, ela reconhece as palavras, ela sabe muitos sinais (P. 5, sala regular).

SD9 - Trabalhamos com escrita no quadro, ela escreve no quadro. Lá no laboratório uma vez na semana, na aula, a gente trabalha bastante a questão da coordenação motora, de ligar pontinhos, mas a questão do digitar como tem muita tecla ela não conseguiu, ela cansou e não quis mais saber. Trabalhamos com joguinhos de sequência, de coordenação, de organização, até porque os jogos mais voltados pra LIBRAS eu não achei conveniente pra ela, porque era uma coisa assim mais de sinal [...] (P. 4, sala regular).

$\mathrm{Na}$ SD8, a professora diz: "A aluna foi alfabetizada desde pequenininha". A professora ali refere-se ao processo da aquisição da Libras, porque ela se identifica como sendo a primeira professora da aluna em outra escola. Diferente da SD9, que a criança não foi alfabetizada e também não tem o acompanhamento na LS. Na SD8, a aluna submeteu-se ao ensino da LS desde a pré-alfabetização, essa aprendizagem da sua língua materna ajudou-lhe no processo de ensino/aprendizagem da segunda língua, língua portuguesa (LP). Ainda na SD8 a professora se refere à mãe da criança: "Conversei com a mãe", e ela considera a participação da família fundamental na formação e no desenvolvimento dos alunos ao cobrar 
da mãe participação na vida escolar da filha. A posição sujeito-professor autoritária se estabelece no processo de ensino-aprendizagem da sua aluna: a professora cumprindo o papel do Estado de ofertar ensino à pessoa Surda. Dessa forma, “a interpelação pela ideologia preside a sua individuação pelo Estado, que, na articulação do simbólico com o político, administra as relações de forças e de sentidos" (ORLANDI, 2015a, p. 190). Para Silva (2015), o analfabetismo é responsabilidade do Estado e da família, então, quando uma dessas partes não cumpre o seu papel, há falta ou há falha.

Ainda no discurso da professora, quando ela diz: "Se ela ouvisse, ela seria a primeira da sala", ela apresenta uma ideologia de que porque a aluna é surda não pode ser a primeira da sala, sendo esta uma demonstração do preconceito de que só os alunos ditos "normais" podem ser os primeiros, os melhores. Rememoramos aí a história da educação do Surdo, ou seja, o processo de significação do aluno Surdo perpassa pelos sentidos da concepção meramente biológica do sujeito-Surdo.

Ao analisarmos a SD8, a professora considera que porque o fato dos outros alunos escreverem na lousa e ela colocar sua aluna Surda para escrever, ela está trabalhando a linguagem ou quem sabe incluindo-a no seio educacional, o que é um grande engano.

Quadros (2004) e Strobel (2012) afirmam que, para o ensino/aprendizagem da língua oral ou escrita com o aluno Surdo, deve haver a utilização de materiais concretos ou imagens. Quando a professora se refere às aulas no laboratório, ela tem no pensamento que essas aulas têm por obrigação serem diferenciadas da sala de aula regular. A professora tem a imagem de que os alunos não se interessam por atividades que são mais trabalhosas e exigem mais deles, por exemplo, ela diz no seu discurso (SD9): "Digitar como tem muita tecla ela não conseguiu, ela cansou e não quis mais saber", ou seja, a professora antecipa os interesses da aluna a partir da imagem que tem de si, o que eu não gostaria, ela também não vai gostar; outro exemplo desse sentimento imaginário da professora é quando ela diz: “Os jogos mais voltados pra LIBRAS eu não achei conveniente pra ela". Como poderia não ser conveniente para a aluna se a LIBRAS é a sua língua materna à qual ela deveria ter o completo acesso? Como essa professora vai alfabetizar essa aluna se, além de não conhecer a LIBRAS, ela priva a aluna de conhecer a língua de sinais? Aqui se apresenta a formação imaginária no fazer/dizer da professora, ou seja, na formação imaginária, o sujeito-professor sabe, ele domina o saber. Assim, a professora escolheu o que entendeu ser melhor para a aluna Surda.

Quadros (2003, p. 101) afirma que foram feitas diversas tentativas de alfabetizar a pessoa Surda na língua portuguesa, desde "métodos artificiais com uma estruturação da 
linguagem até o uso do português sinalizado", mas todas em vão, pois nunca se concretizaram. Mas afinal o que é o português sinalizado, ao qual Quadros se refere?

No Brasil, os métodos artificiais de estruturação de linguagem mais difundidos são a Chave de Fitsgeral e o de Perdoncini. Português sinalizado é um sistema artificial adotado por escolas especiais para surdos. Tal sistema torna sinais da língua de sinais brasileira e joga-os na estrutura do português. Há vários problemas com esse sistema no processo educacional de surdos, pois além de desconsiderar a complexidade linguística da língua de sinais brasileira, é utilizado como um meio de ensino do português (QUADROS, 2003, p. 120).

Pensar em políticas públicas inclusivas exige um olhar mais sensível às especificidades e suas decorrências. Nesse sentido, Quadros (2003, p. 102) compartilha a sua sugestão de que "mudanças profundas requerem a participação política das pessoas surdas para nos apontar o que significam diferenças e como elas precisam ser consideradas no currículo".

Ainda nesse sentido, Santos (2014) destaca as práticas sociais como princípio organizador. Não é este um serviço fácil, pois se faz necessário descobrir quais são as práticas significativa para os diversos contextos, assim essa decisão deve partir de todo o grupo escolar e não de sujeitos isolados, como o docente, por exemplo. Sendo assim, Kleiman (2004 apud Santos, 2007, p. 4) afirma que nas instituições escolares "devem ser criados espaços para experimentar formas de participação nas práticas sociais letradas”.

\subsection{A tecnologia assistiva e os discursos}

A expressão Tecnologia Assistiva (TA) surgiu pela primeira vez no ano de 1988, criada como elemento jurídico na legislação norte-americana, conhecida pelo termo Assistive technology, a Public Law 100-407, que regula as leis do direito dos cidadãos com deficiência nos Estados Unidos da América - EUA, além de prover os fundos para compra de recursos que estes necessitam (BERSCH, 2006, apud GALVÃO, 2009).

No Brasil, esse processo de apropriação do conceito e classificação de Tecnologia Assistiva é muito recente. Segundo Galvão (2009) a expressão Tecnologia Assistiva é utilizada no Brasil frequentemente pelos sinônimos de "Ajudas Técnicas" e "Tecnologia de Apoio”, conforme está na Legislação brasileira, Decreto n 5.296/2004, art. 61: 
Para fim deste Decreto, consideram-se ajudas técnicas os produtos, instrumentos, equipamentos ou tecnologia adaptados ou especialmente projetados para melhorar a funcionalidade da pessoa portadora de deficiência ou com mobilidade reduzida, favorecendo a autonomia pessoal, total ou assistida (BRASIL, 2004, apud GALVÃO, 2009, p. 11).

A TA é um campo de conhecimento amplo e que engloba recursos tecnológicos que vão desde o uso de uma simples bengala, que ajuda na orientação e mobilidade, até "recursos computadorizados de comunicação alternativa, acessibilidade ao computador e acessibilidade a páginas da web" (SANTOS, 2013, p. 4).

Manzini (2005, p. 82) concorda com Santos quando afirma:

Os recursos da tecnologia assistiva estão muito próximos do nosso dia-a-dia. Ora eles nos causam impacto devido à tecnologia que apresentam, ora passam quase despercebidos. Para exemplificar, podemos chamar de tecnologia assistiva uma bengala, utilizada por nossos avós para proporcionar conforto e segurança no momento de caminhar, bem como um aparelho de amplificação utilizado por uma pessoa com surdez moderada ou mesmo veículo adaptado para uma pessoa com deficiência.

Para Galvão Filho et al (2009, p. 26), a definição de TA apresenta-se da seguinte forma:

Tecnologia Assistiva é uma área do conhecimento, de característica interdisciplinar, que engloba produtos, recursos, metodologias, estratégias, práticas e serviços que objetivam promover a funcionalidade, relacionada à atividade e participação de pessoa com deficiência, incapacidades ou mobilidades reduzida, visando sua autonomia, independência, qualidade de vida e inclusão social.

Ainda para Galvão (2009) há um crescimento considerável das Tecnologias de Informação e Comunicação (TICs), e com isso também diferente formas de conhecimento e construção para as mais variadas concepções e possibilidades pedagógicas.

Dias (2011, p. 5) argumenta que "o desenvolvimento tecnológico faz parte da evolução das cidades e repercutem nos modos de vida do sujeito, na forma das relações sociais $[. .$.$] ". Num amplo sentido, a tecnologia tem caminhado em direções que facilitem as$ nossas vidas.

Straub (2009) aborda que as TICs estão presentes em todos os lugares: nos lares, nas escolas, no trabalho, no comércio e no lazer, não importando as condições econômicas do sujeito, e o seu uso no ambiente educacional tem sido tema de estudos de pesquisadores, estudiosos, educadores e também nas políticas públicas. 
De acordo com Santarosa (2001) as TICs têm realizado diferenças significativas na vida social das pessoas. Diante disso, o computador, como uma ferramenta cognitiva, tem favorecido a aprendizagem e se tornado um grande aliado no processo de inclusão de alunos com necessidades educacionais especiais (NEE).

Nessa linha de pensamento, devemos dizer que a TA tem se estendido como um auxílio que promove a ampliação de uma habilidade deficitária, a fim de possibilitar às pessoas deficientes a realização de funções desejáveis.

$\mathrm{Na}$ área da surdez, a dificuldade de leitura e escrita apresentada por alunos Surdos tem assustado os profissionais da educação e, para amenizar a situação, os professores e intérpretes tendem a encontrar na TA uma grande aliada no desenvolvimento da leitura e escrita desses alunos.

No entanto, durante a pesquisa, percebemos na discursividade dos agentes letradores dos alunos Surdos que pouco se tem alcançado durante o processo ensino-aprendizagem desses alunos, talvez por ter dificuldade em como ou o que utilizar na TA.

Para a maioria dos educadores, a expressão TA ainda é algo muito novo e, por estar ainda em construção, o educador ainda não compreendeu com clareza qual é exatamente o papel da TA na vida do educando (GALVÃO, 2009).

Diante do exposto, observamos a fala dos entrevistados quando questionados sobre o uso da TA durante o processo ensino-aprendizagem do aluno Surdo.

SD10 - Utilizo alguns aplicativos. Inclusive a aluna me mostrou alguns aplicativos que eu não conhecia, e até baixei no meu celular, e eu estou usando pra fazer essa comunicação com ela (P. 1, sala regular).

SD11 - Olha a intérprete, igual eu te falei, eles estão usando esse aplicativo mas eu não tenho conhecimento como ele funciona, eu sei que você escreve a palavra lá e aparece no desenho o sinal correspondente. Eu sei que eles usam esse aplicativo, questão visual mesmo... Eu não uso nada, a intérprete que às vezes usa figuras, mas tecnológico mesmo eu não (P. 3, sala regular).

Na SD10 e SD11, os professores falam sobre um aplicativo. Esse aplicativo chama-se HandTalk $^{8}$, muito comum no meio da comunidade surda, porque ele realiza a tradução automática da língua portuguesa para a LIBRAS, considerada uma ferramenta de mediação para a comunicação entre sujeitos Surdos e ouvintes. Seu uso pode ser através de texto, foto e áudio. Foi eleito no ano de 2013 pela Organização das Nações Unidas - ONU como o

\footnotetext{
${ }^{8}$ Disponível em: <http://www.handtalk.me/app>.
} 
"melhor aplicativo de inclusão social" do mundo ${ }^{9}$, criado em Maceió/AL por Ronaldo Tenório, Carlos Wanderlan e Thadeu Luz em parceria com a Universidade Federal de Alagoas - UFAL, após 10 anos de estudos de TA em LIBRAS ${ }^{10}$.

Quando na SD10 o professor diz que "não conhecia o aplicativo" e que agora está fazendo "uso para comunicar-se com a aluna", compreendemos aqui que a aluna é a representação da polissemia, do novo, da ruptura. A necessidade de interagir com a aluna Surda possibilitou a mudança, a transformação, à nova aprendizagem. Dessa forma corrobora com o pensamento de Dias (2009, p. 8) de que é assim, nessa "perspectiva do discurso, que as tecnologias são produzidas pelo sujeito para significar (e se significar) o mundo, a sociedade contemporânea”. Para Quadros (2003) o aluno Surdo se realiza plenamente quando há uma interação linguística dentro de um determinado contexto social.

A professora da SD11, no entanto, diz: "Eles estão usando esse aplicativo, mas eu não tenho conhecimento como ele funciona", apresentando-nos assim o não uso ou a falta de interesse de se desenvolver/compreender na/a linguagem do outro, de contemplar suas peculiaridades e especificidades. Essa professora se acomodou com o que sabe. Não tem interesse em melhorar, crescer, pois, mesmo sabendo que estão fazendo uso de aplicativos que podem ajudar a melhorar a comunicação com os alunos, não busca aprender e compreender o que se passa, uma vez que ela tem a intérprete como intermediadora na comunicação.

Segundo Orlandi (2004 apud Dias, 2009, p. 10) a técnica da escrita ou "tecnologia da escrita" abriria um espaço para o que a autora chama de "forma de relação social". Quando a professora diz, na SD11, "eu sei que escreve a palavra lá e aparece no desenho o sinal correspondente", é a tecnologia significando na linguagem através da transformação social. Orlandi (2004, p. 131) diz que é aí que se deslocam diversas formas de transformações, ou seja, "a própria forma do texto, a forma da autoria, o modo de significar, inclusive, entram também em questão, assim como a própria relação do homem com que referimos".

A sequência discursiva "eu não uso nada" apresenta a ideia de que não se procura melhorar o que já está em funcionamento para atingir outros objetivos. A outra sequência: “mas tecnológico mesmo eu não", apresenta a ideia de oposição, ou seja, o "mas" indica que tem conhecimento do aplicativo e não faz uso dele, o que pode significar que a professora tem a imagem inscrita na ideia de que o tecnológico está atrelado somente aos instrumentos computacionais, não conseguindo perceber que o conceito de tecnologia é bem mais amplo e

\footnotetext{
${ }^{9}$ Disponível em: <http://startupi.com.br/2013/02/hand-talk-app-alagoano-de-acessibilidade-leva-prêmio-daonu/>.

${ }^{10}$ Disponível em: <http:/www.ufal.edu.br/noticias/2013/02/tecnologia-da-ufal-e-usada-em-aplicaivo-de-inclusaopara-surdos/hugo.jpg/view>.
} 
como, provavelmente, por estar inscrita em uma formação mais antiga e de pouca intimidade com os computadores e as tecnologias digitais, não se sente em condições de produzir e interagir com o mundo digital e, por isso, não usa e não deseja aprender. Sendo assim, a dificuldade com o uso das tecnologias, por essa professora, talvez seja o que a impossibilite no uso do aplicativo.

A utilização do aplicativo trouxe novas perspectivas para a aluna Surda e a comunicação desta com o professor e, possivelmente, com os demais colegas da sala. De acordo com Dias (2009, p. 10) o meio tecnológico propiciará uma "construção de conhecimentos do sujeito a cerca de si mesmo e a cerca do mundo". Por meio do aplicativo utilizado pela professora, o aluno encontrou meios de apresentar a estrutura da língua de sinais, que é a sua língua materna. Ainda para Dias (2016) a tecnologia tornou-se um recurso da prática cotidiana do sujeito, a fim de possibilitar mais rapidez e eficiência na vida humana, imprescindível para a existência social. Assim, a aluna Surda que promoveu a interação entre o sujeito-professor e sujeito-aluno, desestabilizando os sentidos postos de que o professor é quem promove a interação em sala de aula.

Durante as entrevistas foi possível perceber, nas discursividades apresentadas por outros professores, que o uso do "tablet, celular, computador" foi um aliado no trabalho em sala de aula com relação à TA no processo ensino-aprendizagem do aluno Surdo, o que se percebeu como frequente. Vejamos:

SD12 - Os meios digitais que usamos com ele é o tablete celular, se tivesse Datashow pra todo mundo pra mostrar as coisas, mas é uma realidade que hoje não existe, mas que deve um dia chegar, o acesso a todos (P. 2 Sala regular).

SD13 - Na sala de aula, não trabalhamos nada, digital não, tem o momento de vídeo que ela gosta de assistir desenho ou filmes que são passados. Pesquisei e não encontrei nada pra ela, uma atividade voltada pra Surdo eu não encontrei ainda não (P. 4 Sala regular).

SD14 - Levamos no laboratório para vídeo aula de LIBRAS, e tem jogos também, só que assim, essa questão de jogos quem trabalha é a intérprete. Aqui na escola sempre funcionou assim, nós passamos para as intérpretes e elas preparam as aulas na linguagem deles, então assim, hoje eles usam bastante o celular (P.5 sala regular).

SD15 - Usamos celular, tablete e notebook com frequência (TILS1).

SD16 - Durante as aulas, utilizo o tablet pra fazer pesquisa na sala de aula, quando estamos no reforço eu uso tablet, computador com jogos e objetos de gravuras, materiais físicos mesmo (TILS3).

SD17 - Todo início de ano a gente faz uma lista de pedidos de alguns materiais necessários. 
Por que às vezes acaba ficando que repetitivos os mesmos materiais. A gente tem um dominó de frases relacionadas á frases, a construção de frases na língua portuguesa, e nós temos imagens também relacionadas ao trânsito, aos meses do ano, a relação de tempo e espaço, então esses materiais que são básicos, por exemplo: nomes de animais, de grupos específicos como de frutas, esses nós temos, sempre nós temos, mas a maioria a gente acaba confeccionando com material reciclado, porque a maioria do trabalho que a gente faz e respaldado nesses jogos, porque ele promove interesse, não tendo esse material acaba ficando falho o atendimento (PSRM 1).

SD18 - Sim, utilizamos jogos pedagógicos como: dominó de palavras e frases, softwares educativos para trabalhar a figura (PSRM 2).

Nas SD12, SD14, SD15 e SD16, todos utilizam o tablet e celular, o que corrobora com Dias (2011, p. 178) quando ela diz que a tecnologia ocupa uma posição primordial no funcionamento da cidade, e porque não dizer da acessibilidade ${ }^{11}$, de forma que não há mais possibilidade de pensarmos, seja qual for a situação, "senão perpassando pela questão da tecnologia".

Nesta atualidade, é pela tecnologia que a gestão da sociedade se dá por meio de artefatos construídos para fins diversos. Podemos citar o computador, os celulares (smartphones), tablets, máquinas digitais para pagamentos de contas, "relógio ponto" digital, micro-ondas, entre tantos outros para os quais poderíamos apontar e que modificam, cotidianamente, os modos do sujeito se relacionar sejam com outros sujeitos, seja com as demandas cotidianas (DIAS, 2011, p. 178, grifo do autor).

Rojo (2009 apud Santos, 2014) assevera que a escola deve estar preparada para receber e conduzir esse aluno a espaços cada vez mais digitais, assim ela tem a oportunidade de ajudar esse aluno a experimentar esses novos espaços e as tendências tecnológicas, incentivando-o a ter uma postura crítica.

Para Orlandi (2007a, p. 77) no discurso não há sentidos sem a possibilidade de pontos de deriva, e, consequentemente, sem interpretação, com a "noção do discurso se trabalha a incompletude da linguagem, não como algo negativo, mas como o lugar do possível".

Sendo assim, quando na SD12 o professor diz "se tivesse o Datashow...", a falta do "Datashow" para as atividades em sala, para que o "acesso a todos" fosse possível, o professor coloca aqui como uma falha, uma carência, uma necessidade, abrindo uma lacuna entre o dizer governamental e a realidade escolar vivenciada por ele. Isso nos remete ao dizer de Straub (2009) quando aponta a falha no processo educacional das políticas públicas quanto

\footnotetext{
${ }^{11}$ Acréscimos da pesquisadora.
} 
ao uso das TICs. Segundo a autora, existe "[...] uma formação imaginária do governo sobre a escola e a tecnologia, a imagem que o governo tem da escola e do sujeito-escolar na relação com a sociedade" (STRAUB, 2009, p. 58). No entanto, é preciso enfatizar que a aprendizagem eficiente dos alunos, seja com deficiências ou não, está atrelada a atividades diversificadas que podem ser planejadas e executadas com eficácia, sem, necessariamente, estar ligada às ferramentas digitais.

Na Lei no 13.005, de 25 de junho de 2014, que aprova o Plano Nacional da Educação PNE, no art. 11, Metas e Estratégias, item 4.5, diz: Aprova meta de adequação na arquitetura, transporte acessível, o fornecimento de material didático e de recursos de Tecnologia Assistiva no contexto escolar.

No Decreto 7.611/2011, apresenta-se a Educação Especial e o Atendimento Educacional Especializado, no parágrafo 4:

\footnotetext{
A produção e a distribuição de recursos educacionais para a acessibilidade e aprendizagem incluem materiais didáticos e paradidáticos em Braille, áudio e Língua Brasileira de Sinais - LIBRAS, laptops com sintetizador de voz, softwares para comunicação alternativa e outras ajudas técnicas que possibilitam o acesso ao currículo.
}

Dessa forma só podemos pensar em uma escola inclusiva quando esta compreende as diferenças dos alunos no processo ensino-aprendizagem, quando esta busca a participação de todos os alunos sem distinção, respeitando suas especificidades e individualidades, adotando práticas pedagógicas que atenda da melhor maneira todos com qualidade, mas, para que haja uma melhoria, fazem-se necessárias mudanças, "exige-se trabalho em muitas frentes". (MANTOAN et al., 2010, p. 10)

Na SD13 o discurso da professora com relação à TA é de inexistência de uso: "Não trabalho nada, digital, não", ou quando ela diz; "Pesquisei e não encontrei nada pra ela". Gallo (2012, p. 62) expõe sobre o uso da tecnologia apontando que, "para nós educadores, a relação com essa rede tecnológica passa pela compreensão de que se trata de algo complexo, mas que se sustenta por uma memória que nós mesmos colocamos à disposição”. A autora complementa ainda dizendo que "[...] essa memória só chega a constituir conhecimento para o sujeito "internauta" na medida em que ele mobiliza saberes de memória discursiva".

Esse recorte marca muito pela sequência negativa no discurso da professora: "Não, nada não, ainda não", ou seja, talvez, de forma inconsciente, a professoratente justificar que sabe que tem que trabalhar de forma diferenciada com a aluna Surda, devido ao comprometimento que apresenta, mas parece ter certa resistência. Pensamos que a resistência 
possa ser quanto as mudanças que deveriam ser feitas na sua atuação pedagógica, ao novo que impõe pelo uso das tecnologias e ao diferente que se apresenta pelo comprometimento apresentado pela surdez da aluna. Questões que, de certa forma, desestabilizam o fazer docente, e novamente os sentidos do professor "sabem" que se apresentam de maneira diferente, ocorrendo um deslize nos sentidos estabilizados.

Na SD14 o discurso da professora traz o sentido de que a escola parece apresentar uma estrutura fixa de como trabalhar com alunos Surdos, utilizando a intérprete como intermediária no processo professor-aluno. Isso, de certa forma, retira do professor a responsabilidade pela aprendizagem da criança, pois são as intérpretes as responsáveis por interagirem com os Surdos. Nesse processo, quanto ruído é possível acarretar? $\mathrm{Na}$ comunicação professor-intérprete, pode-se dizer que já não há $100 \%$ de comunicação, pois as interpretações sempre podem ser outras e, a partir do que a intérprete compreende, ainda há o processo entre intérprete-aluno Surdo, em que outros fatores vão influenciar. É complexo pensar em como as informações estão chegando aos alunos, pois, em cada etapa, funcionarão as condições de produção, de formação discursiva, de formação ideológica e de memória discursiva de cada sujeito.

De acordo com Orlandi (2007b) as posições autor e efeito leitor são afetadas pela natureza da materialidade significante em que se configuram. Assim, a matéria significante afeta o gesto de interpretação e, consequentemente, a posição-sujeito autor e a posição-sujeito leitor (intérprete). Dessa forma, o que temos "não é transmissão de informação, mas efeito de sentido entre locutores, daí decorre o que se pode chamar de efeito-leitor".

A noção de efeito supõe, entre outras coisas, a relação de interlocução na construção de sentidos. Sem esquecer que os sentidos não são propriedades privadas: nem do autor, nem do leitor. Tampouco derivam da intenção e consciência dos interlocutores. São efeitos da troca de linguagem. Que não nascem nem se extinguem no momento em que se fala (ORLANDI, 2012, p. $14)$.

Na SD16, diferente da SD14, a professora da SRM assume a responsabilidade pela aprendizagem do aluno Surdo, com o uso do pronome "eu". Tem a imagem de que os alunos consideram as ferramentas digitais interessantes e motivadoras, por isso utiliza esses materiais no reforço.

Voltando na SD13, a professora demonstra desconhecimento sobre as inúmeras TAs disponíveis para o sujeito Surdo, não sendo só especificamente as digitais, como explica Galvão (2009). TA é tudo aquilo que pode facilitar o acesso ao ensino-aprendizagem do aluno 
especial, no caso, do aluno Surdo. Quadros (2004) sugere o uso de imagens, objetos concretos, exemplos do dia a dia utilizados pelas pessoas, aplicativos que traduzam, além de vídeos em LIBRAS e diversos outros materiais disponíveis e ao alcance de todos. Assim, corroborando com Galvão (2009) temos, nas sequências discursivas a seguir, o uso de equipamentos e materiais em sala de aula com alunos Surdos, alguns adquiridos pelas escolas e outros produzidos pelo educador:

SD19 - "computador com jogos e objetos de gravuras, materiais físicos mesmo" (PSRM).

SD20 - “dominó de frases relacionadas á frases", "imagens também relacionadas ao trânsito, aos meses do ano, a relação de tempo e espaço", "nomes de animais, de grupos específicos como de frutas". Esses nós temos, sempre nós temos, a gente acaba confeccionando com material reciclado, porque a maioria do trabalho que a gente faz é respaldado nesses jogos, porque ele promove interesse (PSRM).

SD21 - "jogos pedagógicos como: dominó de palavras e frases, softwares educativos para trabalhar a figura" (TILS).

Na SD19 percebemos que no espaço da SRM, talvez por ter menos alunos para atender, a professora oferece aos alunos uma oportunidade diferenciada da sala de aula, ou seja, possibilitamaior interação entre professor e aluno Surdo. A abstração da linguagem pode ser mais bem apreendida pelo aluno Surdo por meio de "materiais físicos mesmo", como diz a professora, pois esses significam, têm sentido, ao contrário da língua portuguesa que, para ele, se apresenta sem sentido, vazia.

Na SRM1 da SD20, quando a professora faz uso do pronome pessoal "nós" e a expressão "a gente", forma coloquial do mesmo pronome, isso reforça que ela envolve uma equipe que se organiza para planejar as aulas. Ao mesmo tempo em que esse dizer se relaciona com o fazer em equipe, também pode eximir de si a responsabilidade pelo processo.

A professora tem a imagem de que os alunos só se interessam por formas lúdicas de ensino, com uso de jogos, figuras, cartazes, pois, a imagem que ela tem dos alunos é o que provoca interesse nos alunos. Dessa forma, busca utilizar esses materiais como forma de interagir com eles, de tentar alcançá-los.

Ao considerarmos o desenvolvimento escolar dos alunos Surdos, constatamos a importância ímpar no uso dos recursos da TA para o sucesso escolar desses alunos. Sendo assim, independentemente de quais necessidades educacionais especiais apresentem, todos os alunos têm o direito de participar do processo ensino-aprendizagem em salas de aulas comuns, e a escola é um espaço importante nesse quebra-cabeça, promovendo estratégias e 
adaptações para garantir significativas aprendizagens a esses alunos. Para Orlandi (2013, p. 200),

Transformar este estado de coisas, este funcionamento ideológico, interrogar o que é dito, neste imaginário social, como democracia, como igualdade, só pode se dar em uma relação com uma forma de conhecimento que pense uma relação dinâmica entre indivíduo (sujeito individuado) e sociedade. Isto porque, segundo o que pensamos, a instituição não trata com sujeitos, mas com indivíduos no sistema capitalista, que é seu modo de serializar, dividir os sujeitos em suas relações.

Manzine (2005) afirma que a TA tem se revelado um instrumento relevante para auxiliar, aprimorar e ampliar as habilidades dos alunos com deficiência, visto que contribuem para que esses alunos superem as expectativas pedagógicas de forma independente e significativa. A confirmação desse argumento encontra-se nos documentos oficiais, como o Decreto $\mathrm{n}^{\mathrm{o}} 3.298$, de 20 de dezembro de 1999, e o Decreto $\mathrm{n}^{\mathrm{o}}$ 6.949, de 25 de agosto de 2009, e na atual política de educação especial que incentiva a utilização pedagógica da Tecnologia Assistiva na escola (ASSIS, 2005 apud ALMEIDA, 2011).

Nesse aspecto, Santos (2014) afirma que o uso das TICs nos espaços escolares pode satisfazer os desejos e atender às necessidades daqueles que acreditam na funcionalidade de qualquer letramento desejado, a fim de proporcionar ao sujeito-aluno o desenvolvimento de sua capacidade ao agir. 


\section{AS POLÍTICAS PÚBLICAS DA INCLUSÃO AOS SURDOS}

"Todos são iguais perante a lei, sem distinção de qualquer natureza garantindo-se aos brasileiros e aos estrangeiros residentes no País a inviolabilidade do direito à vida, à liberdade, à igualdade, à segurança e à propriedade."

(BRASIL, 1988)

A epígrafe escolhida é um recorte do artigo $5^{\circ}$ da Constituição Federal Brasileira de 1988 - CF/88. Nesse trecho chamou-nos a atenção quandodiz: "Todos são iguais perante a lei, sem distinção de qualquer natureza".

Quando se diz "sem qualquer distinção", entendemos que quer dizer que não pode haver diferença entre sujeitos-cidadãos da nação brasileira, não deve haver desigualdade entre o negro e o branco, entre o pobre e o rico, o deficiente e o não deficiente. O Estado, em seu discurso jurídico, tem tentado tornar os sujeitos iguais. Esse sujeito jurídico, segundo Pêcheux (2009), é o sujeito assujeitado aos efeitos de sentido sob a forma da autonomia, completamente tomado por efeitos ideológicos presente nos diversos discursos, com ideia de mascarar o sentido das palavras e dos enunciados.

Embora tenhamos presenciado muitas ações sociais e políticas afirmativas contra as diferenças, o Brasil não tem conseguido ocultar as desigualdades sociais. Segundo a Organização para a Cooperação e Desenvolvimento Econômico - $\mathrm{OCDE}^{12}$, o Brasil ocupa o $37^{\circ}$ lugar de educação no ranking de todos os países participantes, perdendo somente para o México. O discurso de um Brasil de todos e/ou para todos, que repetidamente tem ecoado em nossa memória através da mídia, nos parece um tanto desarmônico com a realidade atual, pois o Brasil, em termo de nível de escolaridade, medido no ano de 2015 pela OCDE, ocupa a posição 34 de 38 países participantes. Quanto ao desempenho dos alunos, a classificação é ainda pior, ficando em penúltimo lugar, amargando a $37^{\mathrm{a}}$ colocação. E finalizando esses tristes dados, no requisito de desigualdade social, o Brasil ocupa a $30^{\mathrm{a}}$ colocação.

Sendo assim, é importante apresentarmos em que circunstância, ou melhor, em quais circunstâncias foi criada a Constituição Federal Brasileira de 1988 (CFB), para contextualizar o artigo $5^{\circ}$ desta Constituição. Para Pêcheux (2010), o discurso é sempre dado a partir das

\footnotetext{
${ }^{12}$ A OCDE tem sede em Paris, na França, e reúne algumas das principais economias do mundo entre seus 34 membros. A organização atua com pesquisas de estudos sobre a economia internacional, e, em especial, da situação de seus países-membros em diversas áreas como educação, combate à corrupção e governança com foco no livre-mercado. Também serve para monitorar se os seus membros estçao implementando as políticas combinadas - e força-los a implementar, caso não estejam. (IANDOLI, 2017).
} 
Condições de Produção (CP), e que essa CP será compreendida como entremeio da produção da ação do discurso e suas circunstâncias. O texto aqui apresentado, sobre as condições de produção da Constituição, foi encontrado na página do portal do "Planalto da Presidência da República".

A conhecida CF foi promulgada em 5 de outubro de 1988, após contados os 20 anos da então ditadura militar, marcando o processo de redemocratização. Segundo o portal governamental, a CF foi elaborada nesse momento pelo Congresso Constituinte, ou seja, deputados e senadores eleitos democraticamente em 1986, os quais assumiram seus cargos em 1987.

Nesse período houve grandes avanços, dentre eles: a implementação do Sistema Único de Saúde - SUS, do novo Código Civil e do direito da criança e do adolescente. O intuito da Constituição era de pacificar os conflitos e interesses da sociedade. Nesse sentido ela estabelece as regras que dispõem os direitos basilares do cidadão e o aparelhamento dos poderes, do Estado e da Democracia de ordem econômica e social.

Possenti (2004) defende que, se tratando de $\mathrm{AD}$, o conceito de $\mathrm{CP}$ não tem caráter psicossociológico, mesmo em situações consideradas concretas, utilizando somente as condições históricas de produção. Mussalim e Bentes (2007, p. 369) também afirmam que na $\mathrm{AD}$ o conceito de $\mathrm{CP}$ exclui o caráter psicossociológico, argumentando que os "contextos imediatos somente interessam na medida em que, mesmo neles, funcionam condições históricas de produção", ou seja, estão inseridos dentro de uma história, uma vez que os enunciadores se assujeitam à sua Formação Discursiva (FD).

Assim sendo retomamos a pergunta: Quem é "todos" para o Estado? A quais distinções o Estado se refere ao dizer "sem distinção de qualquer natureza"? Quando colocamos a palavra "todos", estamos elevando todos os sujeitos em patamar de igualdade perante a lei, oportunizando que estes sujeitos usufruam dos mesmos direitos.

Nesse sentido compreendemos que, mais do que o reconhecimento das necessidades específicas da deficiência, o Estado deve buscar coletivamente formas de cumprir com os plenos direitos de todo deficiente. Ao afirmar no seu texto sobre educação inclusiva, ele está afirmando também a importância do respeito às adversidades e à desigualdade, não devendo essas especificidades se transformar em elementos de exclusão.

$\mathrm{O}$ respeito à adversidade, efetivado no respeito às diferenças, impulsiona ações de cidadania voltadas ao reconhecimento de sujeitos de direitos, simplesmente por serem seres humanos. Suas especificidades não devem ser elemento para a construção de desigualdades, discriminações ou exclusões, 
mas sim, devem ser norteadoras de políticas afirmativas de respeito à adversidade, voltadas para a construção de contextos sociais inclusivos (BRASIL, 2004, p. 7).

Reafirmando a igualdade de todos perante a lei, no art. 4 do Estatuto da Pessoa com Deficiência, da Lei no 13.146, de 06 de julho de 2015, em seu capítulo "Da igualdade e da não discriminação", determina:

Art. $4^{\circ}$ Toda pessoa com deficiência tem direito à igualdade de oportunidades como as demais pessoas e não sofrerá nenhuma espécie de discriminação.

$\S 1^{\circ}$ Considera-se discriminação em razão da deficiência toda forma de distinção, restrição, ou exclusão, por ação ou omissão, que tenha o propósito ou o efeito de prejudicar, impedir ou anular o reconhecimento ou o exercício dos direitos e das liberdades fundamentais de pessoa com deficiência, incluindo a recusa de adaptações razoáveis e de fornecimento de tecnologias assistiva.

É comum em nossa sociedade e principalmente no âmbito escolar, encontrarmos pessoas que tenham algum tipo de deficiência, seja ela, física, motora, visual, auditiva, etc., e cada uma tem suas particularidades. No caso do sujeito Surdo, o que o diferencia é a língua, ou seja, a sua comunicação. Enquanto a maioria da população, sendo ouvinte, comunica-se pela oralidade, o Surdo comunica-se por meio da modalidade visual-motora, ou seja, por meio das mãos e utilizando os olhos.

Para Perlin e Souza (2015) os Surdos, quando possuidores da língua de sinais, fazem uma leitura de mundo diferente dos ouvintes, pois eles (Surdos) constroem conhecimentos e compreendem o ambiente ao seu redor por meio do visual/espacial, enquanto o ouvinte é um sujeito verbal/oral. De acordo com Skliar (2003, p. 11) as representações do sujeito Surdo constituem-se de diferenças que devem ser reconhecidas por ser uma experiência visual; por ser uma "identidade múltipla ou multifacetada", localizada no discurso da deficiência.

A Declaração de Salamanca foi um marco de grande importância para os deficientes, pois estes passaram a ter o direito de estudar em salas de aula regular junto com todos os outros alunos ditos "normais", dando espaço então à chamada educação inclusiva.

Todas as escolas deveriam acomodar todas as crianças independentemente de suas condições físicas, intelectuais, sociais, emocionais, linguística ou outras. Deveriam incluir crianças deficientes e superdotadas, de rua e que trabalham, de origem remota ou de população nômade, pertencentes a minorias linguísticas, étnicas ou culturais e crianças de outros grupos em desvantagem ou marginalizados... No contexto destas linhas de ação o termo 'necessidades educacionais especiais' refere-se a todas aquelas crianças ou 
jovens cujas necessidades se originam em função de deficiência ou dificuldades de aprendizagem, (...) As escolas têm que encontrar a maneira de educar com êxito todas as crianças, inclusive as que têm deficiências graves (DECLARAÇÃO DE SALAMANCA, 1994).

Em 2002, foi promulgada a Lei $n^{\circ} 10.436$, que reconhece a Língua Brasileira de Sinais como segunda língua oficial no Brasil, reconhecendo a língua materna dos Surdos.

Art. $1^{\circ}$ É reconhecida como meio legal de comunicação e expressão a Língua Brasileira de Sinais - LIBRAS e outros recursos de expressão a ela associados.

Parágrafo único. Entende-se com Língua Brasileira de Sinais LIBRAS- a forma de comunicação e expressão, em que o sistema linguístico de natureza visual-motora, como estrutura gramatical própria, constituem um sistema linguístico de transmissão de ideias e fatos, oriundos de comunidades de pessoas surdas do Brasil (BRASIL, 2002).

Três anos após a Lei da LIBRAS, no dia 22 de dezembro de 2005, o presidente em exercício assinou o Decreto $n^{\circ} 5.626 / 2005$, que valida a Lei 10.436/02. Esse decreto tornou-se um grande marco para toda a comunidade Surda e, por se tratar de um documento de extrema importância, disponibilizamos na íntegra a Lei 10.436/02 no Anexo A e o Decreto 5.626/05, no Anexo B.

\subsection{O sujeito-aluno Surdo, os agentes letradores e os sentidos do discurso jurídico}

A maior dificuldade encontrada por alunos Surdos nas escolas é a barreira da comunicação. Mesmo que a Lei n. 10.436/02 e o Decreto n. 5.626/05 determinem o uso e a difusão da língua de sinais, muitos alunos e professores são desconhecedores da LIBRAS, o que provoca uma desigualdade linguística e dificulta o acesso às atividades trabalhadas em sala de aula (QUADROS, 2004), como podemos perceber nos recortes das entrevistas com os professores e a coordenação a seguir.

SD22 - Quando eu não sei alguma coisa eu corro na auxiliar, e se ela não sabe também ela corre na apostila dela, então a gente vai tentando fazer o nosso melhor pra aluna. Depois de um tempinho você até perde o medo e o receio, mas assim, o "baque" pra você começar a trabalhar com a linguagem de sinais, foi um pouquinho assim... posso dizer, você teve medo? Não, não tive medo, acho que foi um pouquinho de insegurança para trabalhar em algo que você não conhecia. Aí você começa a pesquisar, começa a estudar, você busca (P. 4, sala regular). 
SD23 - Para nós é muito novo, eu não sei como trabalhar com Surdo, acho que a gente tem que ser honesto, eu não sei, a professora tá tentando de todas as formas, mas também não sabe. A gente na rede teve muito curso de como trabalhar com crianças com déficit de aprendizagem, crianças especiais, mas eu não sei como lidar com uma criança Surda. Porque se, por exemplo, eu tendo o intérprete lá do lado dela, eu penso que seria muito mais fácil para mim como coordenadora e pra professora trabalhar, porque 0 intérprete, ele conseguiria ensinar a língua de sinais mais fácil para ela, só que na verdade está meio que "brincando de casinha" aqui, está empurrando uma coisa de barriga, que eu não acho certo, mas foi o melhor que se pôde fazer pela menina. Na verdade se eu não tivesse conseguido essa auxiliar que tem um pouco de conhecimento de LIBRAS a aluna estaria com qualquer monitor, fazendo qualquer coisa, por que nós não temos (COORDENADORA).

O discurso da professora da SD22 transmite-nos a imagem de que o trabalho com alunos Surdos é um desafio, é o novo. Como já dissemos anteriormente o novo sempre assusta, causa ruptura e transforma. Esse processo se apoia nos multiletramentos que se baseia nos quatro passos: prática situada, instrução aberta, enquadramento crítico e prática transformada, pois é uma constante construção do conhecimento, em que sempre se busca e se aprende mais.

Podemos ver o modo pelo qual o discurso jurídico no Decreto $n^{\circ}$ 5.626/2005, art. 22, que dispõe de profissional capacitado e escolas bilíngues para os alunos Surdos, contradiz com os efeitos de sentido do discurso da professora em questão (SD22), ao relatar que, quando não sabe, ela corre para a auxiliar, e que esta, também não sabendo, recorre à apostila.

De acordo com Cury (2012) a educação brasileira é uma educação seletiva que exerce uma inclusão excludente. O fato de a professora não saber a língua de sinais por si só já demonstra que a lei não está sendo exercida em sua prática social.

Vale ressaltar que responsabilizar os professores e coordenadores por desconhecerem a LIBRAS seria um ato um tanto sem sentido para com o profissional. Ao analisarmos o tempo de formação destes, a graduação muitas vezes deu-se muito antes da promulgação da lei $n^{\circ}$ 10.436/02 e do Decreto ${ }^{\circ}$ 5626/05, que determinam ser obrigatória a inclusão da língua de sinais na matriz curricular do ensino superior para as áreas de educação e saúde, inclusão esta que tem uma carga horária mínima. Por ser uma lei que consideramos praticamente nova e ainda em fase de adaptações, os professores não foram preparados para atender essa especificidade.

Ao buscarmos na história, podemos perceber que nem sempre foi assim, não na França, onde se iniciou a educação com os Surdos. Como exemplo, as escolas públicas de Paris priorizavam no processo pedagógico a Língua de Sinais: 
[...] tinha como eixo orientador à formação profissional, cujo resultado era reduzido na formação de professores surdos para as comunidades surdas e a formação de profissionais em escultura, pintura, teatro e artes do ofício, como litografia, jardinagem, marcenaria e artes gráficas (SILVA etal., 2006, p. 24).

$\mathrm{Na}$ CF diz que a educação é um direito de todos, entende-se como uma ordem jurídica, vê-se que não há uma distribuição efetiva posta sob a igualdade social e as oportunidades, essa universalização se materializa quando há uma ação uniforme dentro da escola regular e quando esse universalismo alcança conhecimentos organizados e sistemáticos (CURY, 2012).

Nesse sentido trazemos Orlandi (2015b, p. 195-196), para complementar quando diz que nós só nascemos cidadãos porque isso nos é imposto por nascimento, porque nascemos em uma República e por direito somos cidadãos, mas a qualificação de cidadãos, ou seja, a condição de cidadãos "é posta pelo sistema capitalista com suas instituições, entre elas a de conhecimento - não nos bastam informações, mas acessibilidade social, mobilidade política e histórica, e estas só podem ser propiciadas pela formação".

É dessa formação que falamos quando colocamos em evidência o fato de a professora, na SD19, não saber como se comunicar com sua aluna e precisar recorrera sua "auxiliar" de sala.

De acordo com o Decreto n ${ }^{\circ} 5.626 / 2005$, no art. 14: "As instituições federais de ensino devem garantir, "obrigatoriamente", às pessoas Surdas acesso à comunicação, à informação e à educação [...] desde a educação infantil até a superior”. Ainda no mesmo capítulo, no $\S 1^{\circ}$, item 1, este deve "promover cursos de formação de professores" e, item 2, "ofertar "obrigatoriamente", desde a educação infantil, o ensino da LIBRAS e também da língua portuguesa, como segunda língua, para alunos Surdos”.

Do ponto de vista da legislação educacional, o acesso à comunicação das pessoas Surdas, a garantia à formação do professor e a presença do intérprete de língua de sinais na sala, na medida da força da lei, quando esta diz "obrigatoriamente", produz-se na textualidade jurídica o apagamento de fronteiras visíveis, deixando implícita a desigualdade entre os sujeitos, ou como diria Pêcheux apud Cury (2012, p. 121) "a particularidade da revolução burguesa foi a de tender a absorver as diferenças rompendo as barreiras".

É sabido que o aluno Surdo tem o direito da presença do intérprete de língua de sinais na sala, no entanto, na SD22 podemos perceber que esse profissional não se encontra em sala com a aluna Surda, a professora dirige-se a uma auxiliar de sala, vejamos: "Eu corro na auxiliar", que por sua vez recorre "à sua apostila", o que demonstra que nem a professora e 
nem a auxiliar de sala estão preparadas profissionalmente para atender às necessidades básicas da comunicação, do ensino-aprendizagem da aluna Surda.

A obrigatoriedade da presença do TILS em sala de aula com a presença do aluno Surdo já existia no Decreto $\mathrm{n}^{\circ} 5.626 / 05$, no art. 23, mas a profissão não era reconhecida na categoria, com isso o fato de não ter formação para esse profissional na época, e, na ânsia de resolver os problemas, estas entidades contratavam conhecedores desta língua para ajudar a resolver o problema. Nesse contexto, se tornou comum a presença do TILS sem formação específica nas escolas (MARTINS, 2008).

Odicionário Aurélio (2010, p. 214) define a palavra "auxiliar" da seguinte forma: "Que ou o que presta assistência a outrem na realização de alguma atividade", ou "Que ou quem tem uma função secundária em alguma atividade". Portanto, quando a professora "corre" na auxiliar, é com o sentimento de ajuda, de realização de uma atividade secundária que irá suprir a falta.

Ainda na SD22, a professora relata que "até perde o medo e o receio" e um pouco mais a diante ela diz que talvez tenha sentido "insegurança". Quando a professora assume que perde o medo, esse "medo" era o sentimento de resistência, do novo, do desconhecido, que se dissipou no momento em que houve o contato, no entanto esta buscou alternativas para atender às necessidades da sua aluna.

Encontramos uma equivocidade de sentidos no discurso da professora na SD22quando diz que teve "medo" e que buscou alternativas para atender às necessidades da aluna. Vimos aqui uma contradição, as necessidades de se sentir parte e incluída é da professora, embora quem precise ser atendida é a aluna. Para Pêcheux (2009) a contradição é parte constitutiva da FD; o autor afirma que "toda prática discursiva está inscrita no complexo contraditóriodesigual-sobredeterminado das formações discursivas que caracteriza a instância em condições históricas dadas" (PÊCHEUX, 2009, p. 197).

Nesse sentido, Pêcheux (2009) argumenta que os discursos e os sujeitos circunscrevem-se em formações discursivas que, por sua vez, não são fechadas, pois recebem e levam elementos de uma parte para outra.

Uma FD não é um espaço estrutural fechado, pois é constitutivamente "invadida" por elementos que vêm de outro lugar (isto é, de outros FD) que se repetem nela, fornecendo-lhes sob a forma de "pré-construídos" e de "discursos transversos" (PÊCHEUX, 2009, p. 310, grifo do autor). 
Dessa forma, há uma ruptura entre as FDs e a noção de interdiscurso, que norteiam os estudos em AD. Para Pêcheux (2009) o discurso só pode ser compreendido no universo do interdiscurso, quando este estabelece uma relação com outros discursos anteriores ou posteriores. Analisando o discurso dessa professora e na proposta de inclusão, pensamos que as discursividades sobre influência e sobre o processo de ensino e aprendizagem da LS contemplam outros discursos que, revelados ou não, são constitutivos.

Sendo assim, buscamos em Pêcheux (2009) os esquecimentos que também são constitutivos dos sujeitos e de seus discursos. Para o autor, o esquecimento número um relaciona-se com o inconsciente, uma vez que o sujeito tende a acreditar que o sentido não é exterior, acreditando ser ele o dominante ao que diz e os sentidos daí advindos. Já o segundo esquecimento aponta para a ilusão que o sujeito tem de ser ele a fonte (início e origem) do seu dizer, como se seu discurso fosse novo. No entanto, Orlandi (2015a) apresenta-nos que tais esquecimentos são característicos de todo sujeito.

Então, ao nos reportarmos aos esquecimentos e à contradição pontuados por Pêcheux (2009) de que os sujeitos, constituídos pelos esquecimentos, não têm controle sobre o que falam, mas, em sua sabedoria iludida, desejam saber e controlar tudo, ou seja, desejam a completude, apresenta-se a contradição no próprio sujeito, por este não ser totalmente livre e nem totalmente assujeitado, ao passo que existe nele, ao mesmo tempo, o desejo e a falta.

Diante do exposto, encontramos as contradições junto ao conceito de educação especial apresentada nas Diretrizes Nacionais para a educação especial inclusiva e sua definição da escola participativa da inclusão:

[...] uma nova postura da escola comum que propõe no projeto pedagógico, na metodologia de ensino, na avaliação e na atitude dos educadores ações que favoreçam à interação social e sua opção por práticas heterogêneas. A escola capacita seus professores, preparando, organizando e adaptando-os para oferecer educação de qualidade a todos, inclusive para os educandos que apresentam necessidades especiais. Inclusão, portanto, não significa simplesmente matricular todos os educandos com necessidades especiais em classe comum, ignorando suas necessidades específicas, mas significa dar ao professor e à escola suporte necessário à sua ação pedagógica (BRASIL, 2001, p. 18).

Com a inclusão dos sujeitos Surdos em escolas regulares, fez-se necessária a contratação de TILS. Quadros (2004) argumenta que, quando há carência desse profissional, a interação entre o Surdo e o ouvinte fica prejudicada, pois os Surdos deixam de participar de atividades sociais, como jogos, cultura e política, além de não conseguirem avançar em termos educacionais, ficando desmotivados e com a autoestima prejudicada. 
Na SD23, o discurso da coordenadora aponta para a importância do intérprete no processo educacional: “O intérprete lá do lado dela, eu penso que seria muito mais fácil para mim, como coordenadora, e pra professora trabalhar". A coordenadora reconhece que o intérprete é essencial para o processo de ensino-aprendizagem da aluna, e que ainda que a auxiliar "tem um pouco de conhecimento de LIBRAS", esta não substitui o profissional intérprete.

Podemos observar que há um descontentamento em suas palavras quando ela diz "está meio que "brincando de casinha"". Observa-se que esta situação está sendo imposta pelo sistema, ou seja, pelo Estado, já que, para Althusser, a escola é um Aparelho Ideológico do Estado (AIE) que age por repressão do Aparelho Repressor de Estado (ARE), na tentativa de igualar o direito à educação a todos, por meio de leis e decretos que exercem força sobre o AIE.

Há dois discursos na fala da coordenadora: o discurso governamental e o pedagógico. De um lado, o pedagógico dizendo que não dá conta, porque não foram preparadas para isso. Do outro, o governamental, dizendo que tem de incluir a criança Surda, mas não oferece condições para isso, por não se responsabilizar por um intérprete para auxiliar a professora. No meio de tudo isso, fica a criança que não está sendo atendida de forma adequada. Nesse processo, percebe-se que a coordenadora não sabe como lidar com o problema, mas está tentando fazer algo por conta própria, ou seja, buscando alguém com conhecimento para tentar ajudar a criança da melhor maneira possível. Ela acha que o governo se isenta de fazer o que deve. Há, dessa forma, uma resistência ao ter que lidar com um problema que não sabe como resolver.

Retomando a SD23, quando a coordenadora diz "se eu não tivesse conseguido essa auxiliar que tem um pouco de conhecimento de LIBRAS", o efeito de sentido pronunciado aqui é o de relação de poder quando diz "se eu não tivesse conseguido", ou como interpreta Pêcheux (1975 apud LAGAZZI, 1988, p. 20): "Forma plenamente visível da autonomia". Referendando-nos em Lagazzi (1988), podemos dizer que a frase "se eu não tivesse conseguido" apresenta uma suposta autonomia do sujeito, não uma autonomia ligada apenas ao sujeito praticando a ação, mas uma supervalorização do agir, como ela sendo o centro da decisão, a detentora do poder. "Nas relações hierarquizadas de comando-obediência dos sujeitos é que se instala um juridismo inscrito nas relações pessoais" (LAGAZZI, 1988, p. 21).

Retomando a frase "a aluna estaria com qualquer monitor, fazendo qualquer coisa", os efeitos de sentidos aqui apresentados determina o que, ou quem, tem o poder de 
decidir as condições de trabalho, mais uma vez voltamos ao ARE. Apossibilidade de a aluna estar a "deriva" em sala "fazendo qualquer coisa" demonstra incoerência entre o que o Estado diz e as regras que lhe são impostas na realidade escolar. Para o Estado, não importa se a aluna está ou não sendo assistida pelo profissional capacitado, a que importa é a imagem que a sociedade e a família têm do AIE, que está cumprindo o seu papel governamental. Portanto nesse jogo de formações imaginárias entre Estado e Escola está presente na relação de força e poder (Orlandi, 2007a).

Podemos dizer que, para Orlandi (2015b) o Estado é estruturado pela falha e pela falta diante de uma sociedade hierarquizada, cujas relações são "de força e poder" que simbolizam o preconceito. Ainda para a autora, "o sujeito não resiste por "mágica”, ou por voluntarismo, mas por condições que abrem para ele um espaço politicamente significado em que os sentidos podem ser outros".

Para Orlandi (2016, p. 77) o lugar da falha é o lugar do impensado, do impossível, é o lugar onde "o irrealizado venha formando sentido do interior do não sentido, momento imprevisível em que uma série heterogênea de efeitos individuais entra em ressonância e produz um acontecimento histórico rompendo o círculo da repetição”.

Para o Estado não importa se a aluna está ou não sendo assistida pelo profissional capacitado. O que importa é a imagem que a sociedade e a família têm do AIE, que está cumprindo o seu papel governamental.

\subsection{A profissão do tradutor e intérprete da língua de sinais - TILS}

A presença do(a) TILS em sala de aula, desde a educação infantil até o ensino superior, como vimos anteriormente, é assegurada pela Legislação brasileira. Segundo as leis, o TILS atua em contextos variados, em um vasto campo de trabalho. A regulamentação da profissão do TILS encontra-se na Lei ${ }^{\circ} 12.319$, de $1^{\circ}$ de setembro de 2010, a qual se encontra no Anexo C, para apreciação do leitor.

É esse profissional que faz a comunicação dos Surdos com os ouvintes e vice-versa. Sua maior área de atuação acontece em seminários, conferências, reuniões, correção de provas e acompanhamento de alunos Surdos em salas de aula. Para Quadros (2004) "o tradutor/intérprete de LIBRAS é o responsável por traduzir a língua de sinais para outra língua oral e da oral para a língua de sinais com modalidades, competência e habilidades que o profissional desenvolve durante a prática". Segundo Perlin (2006, p. 137) os TILS “são 
também intérpretes da cultura, da língua, da história, dos movimentos, das políticas da identidade e da subjetividade Surda".

Quadros (2004) vai mais além quando diz que o TILS deve ter domínio sobre as línguas envolvidas e traduzir com clareza as informações obtidas, respeitando a gramática das culturas envolvidas, os aspectos emocionais e sociais presentes no texto interpretativo. Ainda nesse sentido, Lacerda (2009, p. 21) está em pleno acordo com as declarações de Quadros quando afirma:

[...] o trabalho de interpretação não pode ser visto, apenas, como um trabalho linguístico. É necessário que se considere a esfera cultural e social na qual o discurso está sendo enunciado, sendo, portanto, fundamental, mais do que conhecer a gramática da língua, conhecer o funcionamento da mesma, dos diferentes usos da linguagem nas diferentes esferas de atividade humana. Interpretar envolve conhecimento de mundo, que mobilizado pela cadeia enunciativa, contribui para a compreensão do que foi dito e em como dizer na língua alvo. Saber perceber os sentidos (múltiplos) expressos nos discursos.

Neves (1998) considera mais dois outros atributos associados ao profissional TILS, a saber: a competência comunicativa e a competência tradutória, sendo de suma importância para a consagração dessa profissão. Ambas são de grande relevância na tradução, mas é a competência tradutória que a destingue de outros falantes bilíngues, por envolver técnicas e conhecimentos específicos gramaticais da língua de sinais, suas estruturas e regras de pronunciação, cujo objetivo é a assiduidade na expressão e compreensão.

Embora qualquer falante bilíngue possua competência comunicativa nas línguas em que domina, seja ela qual for, todos possuem competência tradutória com habilidades e conhecimentos. Quadros (2004, p. 11) destaca que o tradutor e intérprete de línguas de sinais deve ter habilidade nas três diferentes formas e modalidades de interpretação:

a) Tradutor-intérprete de língua de sinais

b) Tradução-interpretação simultânea

c) Tradução-interpretação consecutiva ${ }^{13}$

\footnotetext{
${ }^{13}$ Tradutor-intérprete de língua de sinais - pessoa que traduz e interpreta a língua de sinais para a língua falada e vice-versa em quaisquer modalidades que se apresentar (oral ou escrita).

Tradução-interpretação simultânea - é o processo de tradução-interpretação de uma língua para outra que acontece simultaneamente, ou seja, ao mesmo tempo. Isso significa que o tradutor-intérprete precisa ouvir/ver a enunciação em uma língua (língua fonte), processá-la e passar para a outra língua (língua alvo) no tempo da enunciação.
} 
No Decreto 5.626/05, art. 18, define-se que a formação do intérprete deve acontecer em nível superior por meio de curso de tradução e interpretação, no entanto, no decorrer dos dez anos da publicação do Decreto, o art. 19 dispõe que o intérprete poderá atuar obtendo somente o nível médio desde que possua certificado convalidado por instituição de ensino superior e instituição credenciada, conforme o inciso III.

Art. 17 A formação do tradutor e intérprete de LIBRAS - Língua Portuguesa deve efetivar-se por meio de curso superior de Tradução e Interpretação, com habilitação em LIBRAS - Língua Portuguesa.

Art.18 Nos próximos dez anos, a partir da publicação deste Decreto, a formação de tradutor e intérprete de LIBRAS - Língua Portuguesa, em nível médio, deve ser realizada por meio de:

I - cursos de educação profissional;

II - cursos de extensão universitária;

III - cursos de formação continuada promovidos por instituições de ensino superior e instituições credenciadas por secretarias de educação.

Parágrafo único. A formação de tradutor e intérprete de LIBRAS pode ser realizada por organizações da sociedade civil representativas da comunidade surda, desde que o certificado seja convalidado por uma das instituições referidas no inciso III.

A instituição, no inciso III, que se refere o Decreto, é para a formação e a obtenção de certificação de Proficiência em LIBRAS, fornecido pelo Exame Nacional para Certificação de Proficiência no Uso e no Ensino de LIBRAS - Prolibras ${ }^{14}$, realizado pela Federação Nacional de Educação e Integração de Surdo - Feneis, com certificação pelo Ministério da Educação e Cultura - MEC.

O Decreto 5.626/05, no capítulo IV, fala ainda sobre o acesso das pessoas Surdas à educação e destaca a obrigatoriedade do TILS nas escolas:

Tradução-interpretação consecutiva - é o processo de tradução-interpretação de uma língua para outra que acontece de forma consecutiva, ou seja, o tradutor-intérprete ouve/vê o enunciado em uma língua (língua fonte), processa a informação e, posteriormente, faz a passagem para a outra língua (língua alvo).

${ }^{14}$ O Prolibras (Exame Nacional para Certificação de Proficiência no uso e no ensino de Libras e para Certificação de Proficiência na tradução e interpretação de Libras/Português/Libras) certifica pessoas surdas ou ouvintes fluentes em Língua Brasileira de Sinais (Libras) que já concluíram o ensino superior ou o ensino médio. As diferentes Secretarias, o MEC e o Inep, por meio de ações conjuntas, promoveram o primeiro, o segundo, terceiro e o quarto Prolibras, que foram realizados em parceria com a Universidade Federal de Santa Catarina (UFSC), mediante credenciamento desta, pelo MEC. A partir de 2011, a realização do Pro-libras passou a ser de responsabilidade do Instituto Nacional de Educação de Surdos - INES, localizado no Rio de Janeiro-RJ, que realiza as avaliações uma vez ao ano. 
Art. 14 As instituições federais de ensino devem garantir, obrigatoriamente, às pessoas Surdas acesso à comunicação, à informação e à educação nos processos seletivos, nas atividades e nos conteúdos curriculares desenvolvidos em todos os níveis, etapas e modalidades de educação, desde a educação infantil até a superior.

$\S 1^{\circ}$ Para garantir o atendimento educacional especializado e o acesso previsto no caput, as instituições federais de ensino devem:

I - promover cursos de formação de professores para:

a) o ensino e uso da LIBRAS;

b) a tradução e interpretação de LIBRAS- Língua Portuguesa;

c) o ensino da Língua Portuguesa, como segunda língua para pessoas surdas.

Vale ressaltar que o ato de interpretar a LIBRAS exige muito que o intérprete tenha um conhecimento expressivo tanto do português como da língua dos Surdos. Essa mensagem interpretativa deve ter precisão para que a comunicação entre as pessoas de diferentes línguas aconteça.

O intérprete está completamente envolvido na interação comunicativa (social e cultural) com poder completo para influenciar o objeto e o produto da interpretação. Ele processa a informação dada na língua fonte e faz escolhas lexicais, estruturais, semânticas e pragmáticas na língua alvo que devem se aproximar o mais apropriadamente possível da informação dada na língua fonte. Assim sendo, o intérprete também precisa ter conhecimento técnico para que suas escolhas sejam apropriadas tecnicamente. Portanto, o ato de interpretar envolve processos altamente complexos (QUADROS, 2004, p. 27).

Quadros (2004) argumenta que só dominar a língua de sinais não faz da pessoa um intérprete para exercer a profissão; ela pode colaborar com seu conhecimento na falta do profissional, mas nunca poderá ser comparada ao intérprete, pois este deve ser qualificado e estar amparado legalmente para tal profissão.

É importante lembrar que não devemos confundir intérprete de LIBRAS com professor. Professor de surdo não é intérprete; os papéis são imensamente diferentes, e cada um deve desempenhar o seu. O professor do Surdo deve saber a língua de sinais e familiarizar-se com esta língua de forma que consiga se comunicar com seu aluno Surdo, mas não deve ser o tradutor dele. O seu papel é fundamental no aprendizado desse aluno para o completo processo interativo social, cultural e linguístico. Por outro lado, o intérprete faz o papel de mediador entre o professor, os colegas da sala, o aluno Surdo e vice-versa (QUADROS, 2004). 
A seguir trazemos recortes de algumas entrevistas que apresentam dizeres sobre o papel do professor e o papel do intérprete de LIBRAS.

SD24- Eu não sei como contribuir assim diretamente com ele (aluno Surdo), porque eu nunca parei pra pensar, porque geralmente eu faço ali e passo pra intérprete, então eu como professora nunca parei pra pensar sobre isso, em como eu posso colaborar pra melhor com ele. (P. 5, sala regular).

SD25 - Dentro do possível eles vão passando a entender. Vamos tentando ajudar a ver como eles podem estar entendendo o nosso papel. (TILS 2).

Na SD24, a professora demonstra não se sentir responsável pela aprendizagem do aluno Surdo, pois tem a intérprete para fazer isso por ela, e, ao dar sua aula, não o faz pensando no outro, nas necessidades do outro. Preocupa-se em dar aula apenas para aqueles que atendem aos requisitos "normais" dos demais alunos e busca homogeneizá-los nesse processo como se fossem um só.

Vamos compreender esse fato discursivo. Na relação sujeito/sentido com a ideologia inconsciente que ela apresenta, o deslize está em quando a professora diz "passo para a intérprete", porque ela é a professora e detentora do poder, e, a partir do momento em que ela não assume sua postura de professora e delega a responsabilidade a outro, ela demonstra uma falha e uma resistência ao ter de atender o aluno Surdo que está sob sua responsabilidade. Para Orlandi (2016, p. 81), a falha, o deslizamento, o jogo de palavras são aspectos que apresentam uma ideologia inconsciente, "são considerados como estruturas-funcionamentos que dissimulam sua própria existência no interior do seu funcionamento produzindo evidências em que se constitui o sujeito".

Vamos observar os efeitos de sentido na SD24 comparada com a SD25, utilizando os jogos de paráfrases, vejamos:

SD24 - Eu como professora nunca parei pra pensar sobre isso, em como eu posso colaborar pra melhor com ele.

SD25 - Dentro do possível. Vamos tentando ajudar a ver como eles podem estar entendendo o nosso papel.

Há uma diferença de sentidos entre a SD24 e SD25, que deriva da diferença das formações discursivas (FD): a primeira está na posição sujeito/professor, detentora do saber, mas que relata nunca ter entendido o seu papel como educadora do aluno Surdo, demonstrando uma indiferença quanto às suas responsabilidades e ao direito do aluno de ter acesso ao professor como os demais, ainda que com a participação do intérprete; a segunda 
está na posição do sujeito/intérprete que apresenta uma FD de determinação em conscientizar os professores, qual é o real papel do intérprete em sala de aula. A FD estabelecida na análise sobre o discurso, para Orlandi (1996, p. 115), “é a atividade estruturante de um discurso determinado, por um falante determinado, para um interlocutor determinado, com finalidades específicas". "O fato de pertencer a uma ou outra formação discursiva muda o sentido de uma palavra" (PÊCHEUX 1990, apud ORLANDI, 1996, p. 115).

Na SD24 os sentidos de antecipação ou do pré-construído está presente na seguinte formulação: “Ajudar a ver como eles podem estar entendendo o nosso papel”. Esse funcionamento discursivo está sendo fundado por uma estratégia argumentativa (PÊCHEUX 1990, apud ORLANDI, 1996, p. 119), e, por meio de ações praticadas em sala, o intérprete criou uma imagem constitutiva do nível das formações imaginárias, por exemplo, o intérprete da SD24 imagina que estão agindo da forma que os professores percebam que eles são, conforme Quadros (2004), intermediadores entre o ouvinte e o surdo, e vice-versa, mas que a responsabilidade maior com a aprendizagem do aluno Surdo é do educador, cabendo aqui nesse a explicação de Orlandi (1996, p. 116): “A antecipação diz respeito a um mecanismo mais complexo que o de discordar ou concordar".

\subsection{A Sala de Recursos Multifuncionais (SRM) e os efeitos de sentido nos discursos dos professores}

As Salas de Recursos Multifuncionais (SRMs) tornaram-se assunto prioritário nas questões da Educação Especial quando o assunto está relacionado ao processo ensinoaprendizagem de alunos em salas de aula comum. Criada por meio do Decreto $\mathrm{n}^{\circ} 6.571$, de 17 de setembro de 2008, e revogada pelo Decreto $\mathrm{n}^{\circ} 7.611 / 2011$, que dispõe sobre o atendimento educacional especializado, e regulamenta o parágrafo único do art. 60 da Lei no 9.394, de 20 de dezembro de 1996, e acrescenta dispositivo ao Decreto $\mathrm{n}^{\circ} 6.253$, de 13 de novembro de 2017, a SRM destaca-se principalmente na educação inclusiva dando novas direções à construção do Atendimento Educacional Especializado - AEE.

No entanto, o processo de implantação das SRMs já se fazia presente no Ministério de Educação - MEC no ano de 2006, quando este publicou o seguinte documento:

As Salas de Recursos Multifuncionais são espaços da escola onde se realiza $\mathrm{o}$ atendimento educacional especializado para alunos com necessidades educacionais especiais, por meio do desenvolvimento de estratégias de aprendizagem, centrada em um novo fazer pedagógico que favoreça a 
construção de conhecimentos pelos alunos, subsidiando-os para que desenvolvam o currículo e participem da vida escolar (MEC, 2006, p. 13).

Segundo o portal do MEC, na página SECADI, foi emitido no ano de 2014 um novo documento orientador ao qual deram o nome de "Programa de Implantação das Salas de Recursos Multifuncionais", apresentando as seguintes definições:

A Sala de Recursos Multifuncionais cumpre o propósito da organização de espaços, na própria escola comum, dotados de equipamentos, recursos de acessibilidade e materiais pedagógicos que auxiliam na promoção da escolarização, eliminando barreiras que impedem a plena participação dos estudantes público alvo da educação especial, com autonomia e independência, no ambiente educacional e social (MEC, 2014, p. 6).

Partindo desse princípio, o processo de ensino e aprendizagem do público-alvo deve ser realizado em classes comuns de escolas regulares e, quando necessário ou solicitado, o atendimento deve ser acompanhado nas SRMs no contraturno.

Segundo o Decreto $\mathrm{n}^{\circ}$ 7.611/2011, no art. $5^{\circ}$, $\$ 3^{\circ}$ : “As salas de recursos multifuncionais são ambientes dotados de equipamentos, mobiliários e materiais didáticos e pedagógicos para a oferta do atendimento educacional especializado" (BRASIL, 2011).

O Decreto $\mathrm{n}^{\mathrm{o}} 7.611 / 2011$, no art. $1^{\mathrm{o}}, \S 1^{\mathrm{o}}$, preconiza, ainda, que o atendimento educacional especializado:

[...] é um serviço da educação especial que identifica, elabora, e organiza recursos pedagógicos e de acessibilidade, que eliminem as barreiras para a plena participação dos alunos, considerando suas necessidades específicas. (BRASIL, 2008).

Conforme Lei $\mathrm{n}^{\mathrm{o}}$ 13.005, de 25 de junho de 2014, que aprova o Plano Nacional da Educação - PNE, no Art. 11, Metas e Estratégias, item 4.7, apresenta que se deve:

Garantir a oferta de educação bilíngue, em Língua Brasileira de Sinais LIBRAS como primeira língua e na modalidade escrita da Língua Portuguesa como segunda língua, aos(às) alunos(as) surdos e com deficiência auditiva de 0 (zero) a 17 (dezessete) anos, em escolas e classes bilíngues e em escolas inclusivas, nos termos do art. 22 do Decreto $\mathrm{n}^{0} 5.626$, de 22 de dezembro de 2005, e dos arts. 24 e 30 da Convenção sobre os Direitos das Pessoas com Deficiência, bem como a adoção do Sistema Braille de leitura para cegos e surdos-cegos.

Quadros (2006) apresenta que há escolas bilíngues em alguns estados, como podemos verificar a seguir: 
Em alguns estados, há escolas bilíngues para surdos em que a língua de instrução é a língua de sinais e a língua portuguesa é ensinada como segunda língua. Em outros estados a língua portuguesa é a língua de instrução, mas há a presença de intérpretes de língua de sinais nas salas de aula e o ensino de língua portuguesa, como segunda língua para os surdos, realiza-se na sala de recursos (QUADROS, 2006, p. 19).

O preconceito e a falta de interesse na língua de sinais podem ser observados nas considerações de Sá (2003) quando aborda que os Surdos estão condenados ao analfabetismo funcional, sendo impedidos de alcançarem seus estudos, sendo apenas treinados para o mercado de trabalho.

Em todas as partes do Brasil e do mundo os Surdos, têm sido condenados a um analfabetismo funcional, têm sido impedidos de alcançarem o ensino superior, têm sido alvo de uma educação meramente profissional (treinados para o "mercado de trabalho"), têm sido mantidos desinformados, enfim, têm sido impedidos de exercer sua cidadania. Esta situação resulta de múltiplas questões, sendo uma delas, certamente, o processo pedagógico a que foram/são submetidos (SÁ, 2003, p. 91).

Nas SDs a seguir, compreenderemos, no sentido mais amplo, o que Sá afirma.

SD26 - Juntamente com os intérpretes elaboramos um projeto voltado ao mercado de trabalho a pedido dos pais dos alunos Surdos. Nesse projeto são abordadas questões para o mercado de trabalho com ênfase na prova do atesto, e trabalhadas também a leitura e a escrita (PSRM 2).

SD27- Nós utilizamos bastante o site do Professor José Carlos, é um site de jogos na web interativo, mas são jogos didáticos de uma forma geral, principalmente dentro das habilidades matemáticas, a gente acaba utilizando ele bastante agora, para favorecer a parte de letramento mesmo, a gente acaba utilizando imagens da internet e associando, também tem jogos online, nós utilizamos bastante. Eles têm acesso ao wifi, e isso faz com que fique muito mais prazeroso o atendimento quando tem a tecnologia (PRSM 1).

Na SD26 a professora da SRM diz que foi elaborado um projeto "voltado ao mercado de trabalho". Para Orlandi (2015b, p. 194), trabalhar em prol do mercado de trabalho representa um governo capitalista onde o sujeito "não é visto como pessoa pensante, capaz de decidir e participar, mas como consumidor potencial. A educação aparece como um déficit a ser corrigido, na busca do desenvolvimento, que é significado pelo acesso ao trabalho e ao mercado". Na visão Marxista, o trabalho humaniza e transforma a natureza do homem. 
Quando é dito que eles elaboraram um projeto "voltado ao mercado de trabalho a pedido dos pais dos alunos Surdos", é impossível não nos lembrar do discurso de Althusser (1985): “A ideologia é uma 'representação' da relação imaginária dos indivíduos com suas condições reais de existência".

Não são as suas condições reais de existência, seu mundo real que os "homens" "se representam" na ideologia, o que é nelas representado é, antes de mais nada, a sua relação com as suas condições reais de existência. É esta relação que está no centro de toda representação ideológica, e, portanto imaginária do mundo real. É nesta relação que está a "causa" que deve dar conta da deformação imaginária da representação ideológica do mundo real. (ALTHUSSER, 1985, p. 87, grifo do autor).

A professora da SRM torna a repetir que estão abordando questões "para o mercado de trabalhocom ênfase na prova do atesto". O chamado "atesto", ao qual ela se refere, é o documento expedido pelo Centro de Apoio e Suporte à Inclusão da Educação Especial CASIES, quando o Surdo é submetido a uma avaliação de prova escrita e prova didática e alcança a nota mínima para exercer a função como instrutor de LIBRAS nos diversos campos profissionais, conforme orienta o Decreto $\mathrm{n}^{\mathrm{o}} 5.626 / 2005$, capítulo III, Art.6 $6^{\circ} \S^{\circ}$. Esse documento é desejado por Surdos e pais de Surdos, por ser considerado, por eles, a porta de entrada para o mercado de trabalho, conforme reza no art. $7^{\circ}$ que os mesmos poderão exercer a função de instrutor de LIBRAS, se, parágrafo II, possuir o nível médio e o certificado obtido por meio de exame de proficiência em LIBRAS, promovido pelo Ministério da Educação, que no Estado de Mato Grosso tem como órgão responsável pelo exame (atesto) o CASIES.

Para Orlandi (2016, p. 45), o discurso é a materialidade ideológica, e essas formações ideológicas se movimentam de diversas formações discursivas interligadas que determinam o que pode e o que deve ser dito "a partir de uma posição dada em uma conjuntura dada".

Quando no discurso é revelado que os alunos Surdos são preparados para o mercado de trabalho, ecoa em nossos ouvidos mais uma vez a tese de Althusser (1985, p. 104) quando ele diz que os AIEs são organizações e instituições bem definidas em ideologias do Estado: “[...] A ideologia realizada em um AIE garante sua unidade de sistema 'ancorada' em funções materiais, próprias de cada AIE, que não são redutíveis a essa ideologia, mas lhe servem de suporte".

A professora da SRM na SD27 demonstra preocupação e busca aprimorar e auxiliar o aluno Surdo no processo ensino-aprendizagem. Ela tem a imagem de que trabalhar com jogos na $W e b$ ajuda no processo, embora esses jogos não sejam voltados especialmente para o 
público Surdo, por essa razão, faz o uso da conjunção adversativa "mas", deixando claro que mesmo assim os jogos utilizados são didáticos. O uso do pronome "nós" e "a gente" mais uma vez busca trazer a imagem de que se trata de uma equipe e não de uma pessoa. É como se retirasse a responsabilidade de si e incluísse todos os profissionais envolvidos no processo. Tem a imagem de que a aprendizagem atrelada ao uso das tecnologias promove uma aprendizagem significativa e prazerosa.

\subsection{O discurso dos professores de sala regular sobre a formação para atuação com o aluno Surdo}

Vale ressaltar que, quando falamos da escola, estamos falando de um funcionamento discursivo específico, o qual Orlandi (1996, p. 75) classifica o discurso em três tipologias, são elas: "discurso lúdico, discurso polêmico e discurso autoritário", e que, além dessas tipologias, a autora também considera que a linguagem funciona em dois processos: a polissemia e a paráfrase. Na polissemia, segundo a autora, se tem uma "multiplicidade de sentidos", e naparáfrase, "formulações diferentes para o mesmo sentido", no qual a autora atribui o jogo entre o "diferente e o mesmo na linguagem", sendo esse jogo a base da tipologia estabelecida.

Ainda para Orlandi (1996), o discurso autoritário é polarizado pela paráfrase; o lúdico, pela polissemia, e o polêmico, que é o melhor aceito no "jogo entre paráfrase e polissemia, entre o mesmo e o diferente", sendo desejável pela sociedade o discurso lúdico, pois este "entra em contato com o uso para finalidades mais imediatas, comprometidas com a ideia de eficiência e resultados práticos, dessa forma o lúdico é a ruptura, ocupando um lugar marginal".

Nesse sentido, Orlandi (1996, p. 77) define o DP como o que se estabelece pela "metalinguagem e pela apropriação do cientista feita pelo professor", ou seja, o professor se mostra detentor do conhecimento e se torna representante dele, pois ele tem a voz do saber e, por meio do contato do aluno com o professor, este passa a dizer o que aprendeu por meio da inculcação, e, desse modo, a escola cumpre seu papel social de reprodução.

Segundo Penin (2011), conhecer o cotidiano dos sujeitos educacionais na escola é de suma importância para esboçar ações que fornecem informações que nos servirão de orientação para promover a observação em nível mais aprofundado da vivência escolar. A autora defende ainda que só observar não é suficiente, é necessário sair do senso comum para 
um patamar mais elevado de análise, aprimorando suas especificidades em relação à sociedade e ao sistema educacional.

Para Heller (2000), o acontecer histórico faz parte da vida cotidiana das pessoas tornando-a uma essência social. Tal histórico é particular graças aos efeitos produzidos na cotidianidade.

A fim de analisar a discursividade dos professores da sala regular na atuação com o sujeito-aluno Surdo, entendemos como necessário fazer uma abordagem inicial sobre a Educação Especial, trazendo ao conhecimento do leitor a Lei de Diretrizes e Bases da Educação Nacional (LDBN), Lei no 5.692/71 que altera a LDBN de 1961, declarando que para os estudantes com deficiência física ou mental, entre outras deficiências, deve haver tratamento "especial".

Também na LDB n 9.394, de 20 de dezembro de 1996, o art. 59 preconiza que o sistema educacional deve assegurar aos alunos currículo, métodos, recursos e organização específicos para atender às suas necessidades; assegura ainda o término específico àqueles que não atingiram o nível exigido para a conclusão do ensino fundamental, em virtude de suas deficiências.

A LDBN de 1996 define também entre as normas para a organização da educação básica a "possibilidade de avanço nos cursos e nas séries mediante verificação do aprendizado" (art. 24, inciso V) e "[...] oportunidades educacionais apropriadas, consideradas as características do alunado, seus interesses, condições de vida e de trabalho, mediante cursos e exames" (art. 37).

$\mathrm{Na}$ convenção da Guatemala (1999), promulgada no Brasil pelo Decreto $\mathrm{n}^{\circ}$ 3.956/2001, afirma-se que o deficiente tem os mesmos direitos humanos que as demais pessoas, definindo como discriminação qualquer ato que caracterize diferenciação, exclusão ou anulação dos seus direitos humanos e de suas liberdades.

Em seguida, no ano de 2002, foi aprovada pelo Conselho Nacional de Educação/Conselho Pleno - CNE/CP nº 1 as Diretrizes Curriculares Nacionais para a formação de professores da Educação Básica. Esta estabelece que as escolas devem prover em sua organização curricular a formação dos docentes voltada para as necessidades educacionais especiais, que atenda às diversidades e especificidades dos estudantes com deficiência, transtornos globais do desenvolvimento e altas habilidades/superdotação.

Observamos, assim, que, de acordo com o discurso governamental, com relação ao aluno com deficiência, propõe-se a oportunizar o acesso educacional em escolas comuns, com 
professores habilitados a atender as diferentes especificidades, como no caso de surdez, o domínio em língua de sinais - LIBRAS.

Para Tardif (2002, p. 24), a formação do professor está relacionada ao seu dia a dia e à rotina estabelecida na escola, à metodologia e à prática docente de maneira que o "ser do professor, seu estilo, sua personalidade profissional" sejam revelados durante a sua atuação em sala de aula.

No entanto, ao questionar os sujeitos-professores da sala de aula regular, da sala de recursos multifuncionais e os intérpretes, participantes da pesquisa, como foi para eles receberem o aluno Surdo em sala de aula, as respostas evidenciaram a necessidade ou a ausência de formação na perspectiva da educação especial. Vejamos no Recorte as sequências discursivas dos professores da sala regular.

SD28 - Eu não tenho conhecimento em LIBRAS e inclusive a aluna que eu tenho tá me ajudando muito nisso. É sempre uma experiência nova, todo ano você encontra... Quando algum aluno apresenta uma particularidade, é o dobro ainda do desafio, pra você como profissional e como pessoa, aprender a lidar com aquilo, buscar conhecimento fora da sala de aula pra aprender a se adaptar com aquela nova situação que você tem (P.1).

SD29 - Os últimos dois anos no caso, que eu tenho dois alunos surdos, para mim foi mais tranquilo porque esses alunos vieram com o intérprete. $O$ choque mesmo foi quando não tinha intérprete nenhum e esse aluno não era alfabetizado nem com a LIBRAS e muito menos com português. Esse foi cruel, você passa uns dias infelizmente deixando o aluno na sala copiando até você encontrar um método para desenvolver com ele, para que ele faça algo, participe da aula também (P. 2).

SD30 - Quando eu peguei a sala de aula, eu não sabia que tinha um aluno surdo, eles não me informaram... eu descobri quando entrei na sala. Para mim foi um desafio muito grande, porque eu não falo a língua deles, e a gente já tem dificuldade para ensinar o português até para os ouvintes (P. 3).

SD31 - A princípio foi aquela coisa assim, não de rejeição, mas, foi aquela coisa tipo assim, eu vou ter que aprender, porque eu não sei LIBRAS, eu não sei, não sabia como lidar, não sabia como fazer. Aí eu pensei, Nossa! Como é que vai ser isso? Então assim, não é pela aceitação da criança, é pelo fato de que eu teria que aprender para poder ensinar, o que foi uma coisa tipo assim... tá ela não ouve, e agora? Ela tem que aprender, mas ela vai aprender o quê, se eu não sei?O susto em si, não é nem susto, é que você tem que estar preparada para aquilo, e eu não estava preparada, eu sabia que uma hora ou outra eu poderia receber uma aluna assim, mas eu não havia me preparado para isso (P. 4).

Em todas as sequências discursivas, apresentam-se os professores da sala regular sem o domínio da LIBRAS e sem saber como trabalhar com um aluno Surdo em sala de aula. A posição sujeito-professor, detentor do conhecimento, começa a se dissipar, ou seja, uma vez 
que, por exemplo, na SD28, o educador diz: "Não tenho conhecimento em LIBRAS", apresentando um dizer de "desconhecimento" sobre a língua e suas especificidades.

A despeito da formação do professor, Tardif (2002) nos relata que o saber docente deve ser um saber plural, ou seja, proveniente dos quatro pilares do saber: os saberes disciplinares, os saberes curriculares, os saberes profissionais e, por último, considerado pelo autor o mais importante de todos, os saberes experienciais.

Orlandi (2015a, p. 188) esclarece que há três noções fundamentais: "sujeito, indivíduo e pessoa", quando pensamos na "formação do professor que trabalha com diversidade, a deficiência e a acessibilidade". Para a autora, embora distintas, elas estão interligadas pela constituição e produção de diferentes efeitos de sentidos, "sejam na prática da formação e/ou sejam os sujeitos em formação".

Ao retomarmos os discursos dos professores, temos, embora parafraseado, o mesmo sentido nos discursos, o do não saber, do desconhecimento.

SD29 - "Até você encontrar um método para desenvolver com ele".

SD30 - “Eu não falo a língua deles".

SD31 - "Eu vou ter que aprender, porque eu não sei LIBRAS; eu não sei, não sabia com fazer, teria que aprender para poder ensinar; ela vai aprender o quê, se eu não sei?, eu não estava preparada; eu não havia me preparado para isso".

Todos estão na mesma posição sujeito-professor, portanto detentores de conhecimentos (assim deveria ser) e na posição de poder, ou seja, na relação de força e poder.

Para Veiga-Neto (2007, p. 130) "As relações de força constituem o poder, ao passo que as relações de forma constituem o saber". Temos aqui também o sentimento de resistência ao novo, SD30 - "a gente já tem dificuldade para ensinar o português até para os ouvintes"; SD31 -“eu vou ter que aprender"; "eu não havia me preparado para isso"; a materialidade posta nos discursos nos possibilitou perceber certa resistência à nova língua, ação constitutiva da identidade do sujeito quando deparado com desafios que fogem à realidade do dito "normal". Para Skliar (1996 apud CAVALLARI, 2014, p. 42) "acabamos reduzindo toda alteridade a uma alteridade próxima, a alguma coisa que tem de ser obrigatoriamente parecida a nós - ou ao menos previsível, pensável, assimilável”. Em consonância com as afirmações de Skliar, encontramos o dizer de Cavallari (2014, p. 42), que aponta:

A resistência em acolher as diferenças se atrela ao fato de que tudo o que nos parece estranho ou não familiar expõe o não saber ou o não controle, 
desestabilizando o lugar de suposto-saber que é constitutivo da identidade de agentes educacionais sobre tudo professores. Essa redução do estranho em familiar, do diferente em normal, entretanto, inviabiliza uma prática inclusiva que, de fato, contemple a singularidade do sujeito-aluno e a diversidade inevitavelmente presente em todo e qualquer contexto escolar.

Por outro lado, na SD28, temos a relação de empatia do sujeito-professor com o sujeito-aluno quando o sujeito-professor relata que "a aluna que eu tenho tá me ajudando muito nisso", expressando o sentimento de desprendimento e o interesse em aprender, em buscar saber para um melhor desenvolvimento das atividades com os alunos, a fim de que estes consigam ter um bom aproveitamento nos estudos. Surge aí também a ideia do “desafio", ou seja, da superação, tanto o aluno como o professor necessitam dessa superação.

O conjunto aqui nos remete a um conceito de Pêcheux (2009) o interdiscurso, onde os sentidos se relacionam nas FDs, ou seja, os discursos aqui proferidos partem de um préconstruído, um já-dito. Em seguida, passamos para um segundo funcionamento, chamado por Pêcheux (2009, p. 166) de intradiscurso, isto é, o discurso em funcionamento relacionado consigo mesmo. Como se pode ver nas sequências discursivas, todos expressam o "eu", "o que eu digo agora, com relação ao que eu disse e ao que eu direi depois; portanto, o conjunto dos fenômenos de 'co-referência' que garantem aquilo que se pode chamar o 'fio do discurso' enquanto discurso de um sujeito". Nota-se que os sujeitos educadores convocam os agentes educacionais para o seu dizer, quando eles empregam a primeira pessoa do singular "eu", o que produz o dizer sobre o desconhecimento da LIBRAS, que, por sua vez, ocasiona a exclusão do outro (CAVALARI, 2014).

Ao analisarmos a SD31, embora a professora diga que não há rejeição pelo aluno Surdo, as palavras ditas revelam que há um desconforto criado pela situação de ter um aluno com essa deficiência. Desconforto devido ao fato de ela não ter domínio sobre a língua. Tirála da zona de conforto de fazer o que já sabe (paráfrase) incomoda, porque faz pensar, estudar, pesquisar e dá trabalho, e não é isso que as pessoas querem (polissemia): "eu vou ter que aprender", "eu teria que aprender para poder ensinar", "eu não havia me preparado para isso". Passa a imagem de que só vai buscar como resolver o problema se ele aparecer, caso contrário, não vai se mexer: "eu não estava preparada", "eu sabia que uma hora ou outra eu poderia receber uma aluna assim".

A política de inclusão no $\mathrm{CNE} / \mathrm{CP}$ n $^{\circ} 01$ afirma que o Estado "[...] deve prover em sua organização curricular a formação dos docentes voltada para as necessidades educacionais especiais, que atenda às diversidades e especificidades dos estudantes com deficiência". A inclusão de alunos Surdos exige das escolas novas posições que impliquem em formação, 
aperfeiçoamento de todo o corpo docente escolar, mas principalmente dos professores, por meios de cursos na área da surdez, de forma que possam lhes propiciar progressos significativos de aprendizagem.

Contudo Souza e Goés (1999) afirmam que, para que haja um atendimento digno para esses alunos, faz-se necessárias políticas públicas com novas iniciativas pedagógicas, construções de entendimentos políticos pedagógicos. Para Quadros (2003, p. 89) a educação inclusiva se subdivide em um "todos" caracterizando os "deficientes" participantes de um determinado grupo "diferente" de outros grupos, o que não deveria ocorrer se compreendêssemos o que seria essa educação para "todos".

Ao buscarmos na história da educação, observamos que sempre existiu uma diferença entre os alunos ditos "normais" e os deficientes; visto quase sempre como uma opção àqueles que desejam trabalhar com alunos "especiais" ou diferentes dos demais sujeitos (CARTOLANO, 1998).

Na SD30, a professora em questão demonstra, com certa indignação, que não sabia do aluno Surdo em sala: "Eu não sabia que tinha um aluno Surdo, eles não me informaram...", o "eles" ao qual ela se refere é a Escola, a qual, segundo as leis aqui outrora apresentadas, entre outros, deve garantir a inclusão de todos os alunos com equipes pedagógicas preparadas e materiais adaptados. O fato de a professora não saber que havia um aluno Surdo na sala corrobora com Cavallari (2014, p. 31) quando diz que a postura das políticas públicas brasileiras não muda, "ela se caracteriza pelo improviso e despreparo dos profissionais envolvidos em sua implementação".

Mesmo diante da insegurança vivenciada pela professora mediante o novo, ou do diferente, que, na maioria dos casos, o Surdo vira sinônimo de deficiente, "a necessidade de tudo saber e de fornecer respostas acertadas para situações inesperadas constitui a identidade do sujeito educador, além de governar seu pedagógico, tal como sugere a formulação: 'a gente tem que' saber o que fazer" (CAVALLARI, 2014, p. 31).

A formulação "a gente tem que saber fazer", acima citada, dialoga com a SD30, quando diz: "Para mim foi um desafio muito grande" e, com a SD31, quando a professora (P. 4) desabafa: "Eu não havia me preparado para isso". Os efeitos de sentidos aqui apresentados são de que embora não conhecendo a língua do outro, teria que saber como fazer para incluí-lo na sua aula de forma que houvesse o ensino-aprendizagem. Desse modo, mais uma vez concordamos com Cavallari (2014, p. 32) quando diz que "os agentes educacionais, mesmo sem a formação necessária para trabalhar com os alunos ditos especiais, devem acolhê-los no espaço de sala de aula, ainda que isso implique na má qualidade da educação 
oferecida". Mais uma vez se apresenta uma lacuna entre o dizer do Estado e o fazer pedagógico.

Desse modo, trazemos Orlandi (2016, p. 202) que afirma que o "Estado individua/liza este sujeito, pela instituições e pelos discursos, [...] um indivíduo que se identifica por sua inscrição em uma formação discursiva, [...] constituindo-se em uma posição sujeito com sua existência, que se inscreve, com suas práticas, na sociedade". Orlandi (2012 apud BARROS; LOPES, 2016, p. 128) complementa ainda que, com essa individualização do sujeito pelo Estado, o sujeito é atravessado por processos de identificação com os modos e práticas de linguagem do sujeito, transpondo este funcionamento, a conter a relação do sujeito com o outro, posto assim o "acontecimento do significante, ou, o discurso sobre o homem, que fomenta os processos de subjetivação", e que "[...] ao submeter-se à língua, o sujeito está assujeitado ao embate entre o simbólico e o político no qual encontra, como fio do discurso, a conduta do Estado numa determinação histórica”.

Retomando os recortes discursivos, embora as respostas estejam parafraseadas, ou seja, falam a mesma coisa com palavras diferentes, o domínio dos enunciados foram os mesmos assumidos em relação às palavras. Segundo Pêcheux e Fuchs (1975 apud MUSSALIN; BENTES, 2007) esse sentido discursivo ocorre por estarem na mesma FD, pois, no caso em questão, todos estão na posição sujeito - professor da sala regular de ensino. Para Pêcheux e Fuchs (1975 apud MUSSALIN; BENTES, 2007, p. 373):

[...] a produção de sentido é estritamente indissociável da relação de paráfrases entre sequências tais que a família parafrástica destas sequências constitui o que se poderia chamar de matriz do sentido. Isto equivale a dizer que é a partir das relações no interior desta família que se constitui o efeito de sentido, assim como a relação a um referente que implique esse efeito.

Mussalim e Bentes (2007) defendem que o sentido das palavras em um determinado discurso remete-nos à história, e é aí que os enunciados ou discursos recebem o sentido. $\mathrm{Na}$ SD29, o educador diz: "Para mim foi mais tranquilo porque esses alunos vieram com o intérprete. [...] $\mathrm{O}$ choque mesmo foi quando não tinha intérprete nenhum e esse aluno não era alfabetizado nem com a LIBRAS e muito menos com português".

Compreendemos primeiro que ele está retornando a um fato histórico de que no passado em algum momento ele havia recebido aluno Surdo em sala e que não havia intérprete para auxiliá-lo. Segundo Pêcheux (1975 apud ORLANDI, 2016, p. 45) é importante pensarmos nessa materialidade discursiva enquanto nível de existência socio- 
histórica a qual os remeteàs condições verbais de existência, ou seja, "historicidade, interdiscurso, memória discursiva".

O fato de na SD29 o professor trazer em seu discurso a palavra "tranquilo", instigounos a buscar qual é a definição que caberia para o sentido do discurso desse professor em relação à atuação do intérprete em sala. À associação da busca da "tranquilidade" apresentada no discurso do professor, relacionamos o auxílio obtido pelo intérprete nas atividades de comunicação na sala de aula, como já havíamos visto anteriormente que o que define a palavra "auxiliar" é o mesmo que amparar, apoiar, ajudar, socorrer, assessorar, contribuir, assistir, facilitar. Todos esses são sinônimos que cabe bem ao pensamento do professor em relação ao intérprete, principalmente quando ele diz em seu discurso: "Para mim foi mais tranquilo". Mais "tranquilo" porque ali ele teria um ajudador, alguém que iria socorrê-lo, ajudá-lo ou facilitaria a comunicação entre o aluno Surdo e ele.

O sentido discursivo do professor está marcado por procedimentos meta enunciativos que foram produzidos na sua FD à qual está condicionado (ORLANDI, 2016, p. 77). A discursividade d oprofessor na SD26, "esses alunos vieram com o intérprete", o discurso dele está apresentando o "dito" rejeitando o "não dito", ou seja, apoiando-nos em Mussalim e Bentes, podemos dizer que o professor optou por dizer uma coisa só, o "dito", por não haver maneira de dizer as duas coisas de uma só vez.

[...] os processos de enunciação constituem em uma série de determinações sucessivas pelas quais o enunciado se constitui pouco a pouco e que tem por característica colocar o "dito" e em consequência rejeitas o "não dito". [...] Desse modo se acha, pois, desenhado num espaço vazio o campo de "tudo o que teria sido possível ao sujeito dizer (mas que não diz)" ou o campo de "tudo a que se opõe o que o sujeito disse" (PÊCHEUX; FUCHS, 1975 apud MUSSALIM; BENTES, 2007, p. 376).

Em outras palavras, o professor está dizendo que, em algum momento no passado, o aluno Surdo não teve o intérprete para auxiliá-lo e que o ensino-aprendizagem ficou prejudicado por isso. Para Orlandi (2016) o discurso é a base da materialidade ideológica, daí partem várias formações discursivas unidas que determinam o que deve e pode ser dito a partir de uma determinada posição em uma conjuntura dada, realizando, assim, os efeitos de sentidos.

Diante da presente explanação, trazemos Coracini (1995 apud CAVALLARI, 2014, p. 32, grifo do autor), que complementa todo o percurso aqui exposto da seguinte forma: 
O fato de partilhar do mesmo espaço físico não significa "por si só e por força da lei, ausência da discriminação, in-clusão, in-serção social” [...] a vontade de igualar, de homogeneizar na melhor das intenções [...] é que cava um abismo ainda maior entre uns e outros.

Para Cavallari (2014) partindo da premissa de que todos são iguais, ou que talvez esse seja um ideal a ser almejado e alcançado, e a tentativa de igualar os sujeitos é provocada pela educação inclusiva de forma a não deixar que se produzam as transformações necessárias e significativas no contexto escolar. 


\section{EFEITO DE FECHO}

Refletir sobre o letramento de Surdos, sobre como muitos não adquiriram a língua portuguesa e os processos de ensino e aprendizagem em escolas regulares ainda é uma tarefa muito árdua, um trabalho que, de certa forma, assusta e desanima pesquisadores de qualquer área. Ainda assim, com tanta lentidão no desenvolvimento da língua de sinais e com a frequente frustração da não aquisição da L2 pelos Surdos, continua-se a buscar soluções nesse processo de aprendizagem.

$\mathrm{Na}$ análise da materialidade linguística, às concepções práticas de letramento (aquisição da leitura/escrita) e os multiletramentos utilizados no processo ensinoaprendizagem do aluno Surdo, dentro da perspectiva discursiva dos agentes letradores participantes dessa pesquisa, professores da sala de aula regular, professor da Sala de Recursos Multifuncionais e intérpretes de língua de sinais, compreendemos que embora tentassem demonstrar que a alfabetização e a inclusão estavam funcionando, percebemos que há uma in/exclusão, ou seja, o aluno está em sala de aula inserido, mas não incluído como deve ser. Vejamos! Em todas as escolas participantes da pesquisa, nenhum professor da sala regular de ensino domina a língua de sinais. Tem dificuldade em comunicar-se com o aluno Surdo e demonstram despreparo para trabalhar a leitura e escrita como L2 por desconhecer a língua de sinais, sendo assim não sabem como agir em relação ao processo ensinoaprendizagem desse aluno.

Nesses termos, compreendemos que "a questão da interpretação é trabalhada junto à de ideologia, é inseparável dela, pois é no trabalho da interpretação que podemos apreciar os efeitos da ideologia funcionando" (ORLANDI, 2013, p. 4) e, dessa forma, quando o professor não domina a língua de sinais para comunicar-se com o aluno Surdo, tendo a TILS como atravessadora/tradutora, essas interpretações passam a ter outros sentidos, cheios de suas ideologias.

Diante do exposto, buscamos em Orlandi (2012 apud ORLANDI, 2013) que partindo do princípio discursivo do trabalho político, deve-se levar em conta que o sentido é sempre dividido, tendo uma direção que se "especifica na história, pelo mecanismo ideológico de sua constituição; há simbolização de força, de poder, que se estabelecem na divisão própria à sociedade capitalista”. Dessa forma, Orlandi (2012 apud ORLANDI, 2013, p. 6) apresenta que há uma ligação de três noções: "o político, o histórico (o outro, a memória, o interdiscurso) e o ideológico". 
A atitude dos professores em transferir a responsabilidade de educador para o intérprete de LIBRAS remonta-nos ao passado. Quando na idade moderna nascia uma criança Surda, sob sigilo absoluto, havia professores dispostos a prestarem seus serviços para a nobreza, tendo interesses totalmente capitalistas, ou, quando os pais deixavam seus filhos Surdoscom os seus tutores "professores" para aprenderem a se comunicarem, transferindo a responsabilidade familiar para o educador.

Nesse aspecto, Gallo (1992) afirma que, embora sendo o processo de imposição de papéis mais brando, ele continua acontecendo, seguindo exatamente a mesma estrutura da história; a única diferença é que o processo, aqui, é mais velado.

Observamos que, embora os alunos Surdos tenham dificuldade na escrita e leitura da língua portuguesa, eles conseguem utilizar a tecnologia a seu favor por meio do uso do tablet, celulares, notebooks, imagens, jogos pedagógicos e multimídias, dessa forma os intérpretes e professores da SRM utilizam-sem da TA, tanto em sala regular quanto na SRM, o que colabora na aquisição e aperfeiçoamento do letramento, ou seja, da leitura e escrita da L2.

Vimos por meios dos discursos que os professores em sala fazem uso de diversos multiletramentos, mas não os percebem, pois têm o imaginário de que estão dando uma aula "tradicional" e corriqueira tanto para o ouvinte como para os Surdos, sem fazer distinção das diferenças tanto da linguagem como da forma de aprender, o que nos leva a refletir na fala de Pfeiffer (2002, p. 29) quando ela apresenta o processo de escolarização como uma "tirania da igualdade", produzindo o ideal de "um mesmo sujeito" (p. 32).

As realidades encontradas em escolas regulares revelam o que Lorenzetti (2003 apud ALMEIDA, 2015, p. 55) já afirmava em suas pesquisas: “O despreparo e o desconhecimento dos professores para lidar com o aluno Surdo, citando como fator relevante o uso de uma linguagem totalmente oralista no processo de comunicação”. Ou o aluno Surdo é tratado como se fosse um ouvinte que a maioria dos professores espera que este o esteja entendendo e compreendendo a sua posição. Sendo assim, a língua de sinais acaba ficando em segundo plano.

Voltamos ao exemplo desse sentimento imaginário no discurso da professora quando ela diz: "Os jogos mais voltados pra LIBRAS eu não achei conveniente pra ela". Como poderia não ser conveniente para a aluna se a LIBRAS é a sua língua materna à qual ela deveria ter completo acesso? Como essa professora vai alfabetizar essa aluna se além de não conhecer a LIBRAS, ela priva a aluna de conhecer a língua de sinais? O discurso dessa professora nos demonstra a falta de preparo para atuar na educação com um aluno Surdo. 
Segundo Quadros (2004) a criança Surda deve ter contato direto com sua língua materna para que esta possa identificar-se e criar sua própria identidade; ao apoderar-se da sua língua, consequentemente conseguirá aprender e desenvolver a segunda língua (L2).

A impossibilidade do acesso do aluno Surdo a sua língua nos remete novamente á fala de Lorenzetti (2003 apud ALMEIDA, 2015, p. 57) que enuncia: "A defasagem na aprendizagem recai unicamente na deficiência do aluno e na prática, sendo assim pode reverter em ações que, na realidade, marginalizam o aluno e antecipam o fracasso escolar".

Durante todo o processo de pesquisa, identificamos que há o uso da Tecnologia Assistiva no processo de ensino e aprendizagem do aluno Surdo, porém quem faz o uso desses recursos são os professores da SRM e os intérpretes. No entanto eles não entendem como TA, talvez por falta de conhecimento do assunto já que, para Bersch (2013) esse termo Tecnologia Assistiva é novo, ou conforme apresentou em seus discursos, o fato de o nome “Tecnologia” remeter ao imaginário de que são equipamentos digitais.

Já na sala regular, percebemos que os professores utilizam-se somente dos livros e aulas no quadro, deixando sob a responsabilidade do intérprete procurar outros recursos para o desenvolvimento da aprendizagem do aluno Surdo. Essa posição do professor entra em confronto com Bersch e Pelosi (2006) que posicionam a TA como uma busca do professor, com criatividade e como alternativa para que o seu aluno realize atividades corriqueiras que ele deseja ou necessite. Essa seria a forma de o professor valorizar e capacitar o seu aluno a interagir a partir de suas especificidades, desafiando-o ativamente a experimentar e conhecer suas capacidades de forma que construa, individual e coletivamente, novos conhecimentos, dando-lhe a oportunidade de ser autor da sua própria interpretação.

Percorrido esse trajeto, essa pesquisa nos permitiu compreender o processo que produz e mantém, ao longo do tempo, sistemas de ensino desiguais, excludentes e contraditórios sobre os quais se construiu a escolarização brasileira, marcada ao longo do tempo, até os nossos dias, por uma "educação de classe" (ORLANDI, 2008, p. 36) ainda que, imaginariamente, a escola seja significada, na discursividade educacional em circulação em nosso país (CURY, 2008) atualmente, como uma escola para todos.

Dizer que a educação é direito de todos, "um princípio e uma norma do ordenamento jurídico brasileiro" (CURY, 2008, p. 210) é também dizer da contradição que constitui o nosso processo de escolarização, na medida em que "ela não teve e ainda não tem sua distribuição efetivamente posta à disposição do conjunto dos cidadãos sob a égide da igualdade de oportunidades e de condições" (CURY, 2008, p. 218). 
Finalizamos este trabalho com a fala de Lorenzetti (2003 apud ALMEIDA, 2015) ao afirmar que voltamos então à questão da formação do professor que precisa instaurar novos dizeres, tecer e fazer circular novos sentidos no espaço escolar, a fim de romper com a repetição mecânica de situações e tarefas no que se refere às práticas de leitura e escrita desenvolvidas nesse espaço, assumindo seus deveres e consentindo a produção de sentidos ao permitir o desenvolvimento mútuo do aluno Surdo.

Quando falamos em desenvolvimento mútuo, queremos dizer que é em todos os aspectos, ou seja, na comunicação entre professores, alunos e todo o corpo docente com o aluno Surdo em sua língua materna (LIBRAS), bem como o desenvolvimento na aquisição da L2 pelo aluno Surdo, e que, a escola para que seja realmente bilíngue todo o corpo docente e alunos da escola fale as duas línguas, se assim ocorrer, teremos a inclusão desse aluno e efetivamente uma escola bilíngue conforme apresenta o discurso político. 


\section{REFERÊNCIAS}

ALTHUSSER, L. Aparelhos ideológicos de estado: nota sobre os aparelhos ideológicos de estado (AIE). 1918. Tradução de Walter José Evangelista e Maria Laura Viveiros de Castro. 2 ed. Rio de Janeiro: Ed. Graal, 1985.

ARANHA, M. S. F. (Org.). Educação Inclusiva: a fundamentação filosófica. Brasília: MEC/SEESP, 2004. v.1.

ARRUDA, E. C. Linguística, educação e surdez. Fortaleza: Conhecimento, 2003.

ASSIS, C. P.; ALMEIDA, M. A. Um estudo bibliográfico sobre as tecnologias assistivas propostas para alunos com deficiência física. In: VII ENCONTRO DA ASSOCIAÇÃO BRASILEIRA DE PESQUISADORES EM EDUCAÇÃO ESPECIAL. Anais... Londrina-PR, 2011.

BARROS, R. C. B.; LOPES. P. C. Os efeitos de sentidos do termo cultura nos processos de segregação e visibilidade da surdez - a (im)possibilidade de inclusão. In: ORLANDI, E. P.; MASSMANN, D. (Orgs.). Cultura e diversidade. Campinas- SP: Pontes Editores, 2016.v. 1.

BRANDÃO, H. H.N. Introdução à análise do discurso. 3.ed. Campinas-SP: Editora Unicamp, 2012.

BRASIL. Ministério da Educação. Lei de Diretrizes e Bases da Educação Nacional - LDB n 9.394, de 20 de dezembro de 1996. Brasília-DF, 1996.

Congresso Nacional. Legislação específica. Lei $\mathbf{n}^{\mathbf{0}} \mathbf{1 0 . 0 9 8}$, de 19 de dezembro de 2000, eLei no 10.436, de 24 de abril de 2002. Brasília-DF: MEC/SEESP, 1994.

Secretaria de Educação Especial. Deficiência Auditiva. Brasília: SEESP. VI, 1997.

Decreto $n^{0}$ 3.298, de 20 de dezembro de 1999. Regulamenta a Lei $n^{\circ}$. 7.853/1989, dispõe sobre a Política Nacional para a Integração da Pessoa Portadora de Deficiência, consolida normas de proteção, e dá outras providências. Brasília-DF, 1999.

- Ministério da Educação. Diretrizes Curriculares Nacionais para a Educação Especial na educação básica. Brasília-DF, 2001.

. Congresso Nacional. Lei $\mathbf{n}^{\mathbf{0}} \mathbf{1 . 0 4 3 6}$, de 24 de abril de 2002; $181^{\circ}$ da Independência e $114^{\circ}$ da República. Dispõe sobre a Língua Brasileira de Sinais - LIBRAS e dá outras providências. Brasília-DF, 2002.

Decreto $n^{0}$ 5.696, de 2 de dezembro de 2004. Regulamenta a Lei ${ }^{\circ} 10.048 / 2000$, que dá prioridade de atendimento às pessoas que especifica, e a Lei $n^{\circ} 10.098 / 2000$, que estabelece normas gerais e critérios básicos para a promoção da acessibilidade das pessoas portadoras de deficiência ou com mobilidade reduzida, e dá outras providências. Brasília-DF, 2004. 
Decreto $n^{0} 5.626$ de 22 de dezembro de 2005. Regulamenta a Lei ${ }^{\circ}$ 10.436/2002, que dispõe sobre a Língua Brasileira de Sinais - LIBRAS, e o Art. 18 da Lei no 10.098/2000. Brasília-DF, 2005.

Portaria Normativa $n^{\circ} 13$, de 24 de abril de 2007, que dispõe sobre a criação do "Programa de Implantação de Salas de Recursos Multifuncionais".

Ministério da Educação. Secretaria da Educação Especial. Política Nacional de Educação Especial na Perspectiva da Educação Inclusiva. Brasília-DF, 2008.

Lei $\mathbf{n}^{\circ}$ 12.319, de $1^{\circ}$ de setembro de 2010. Regulamenta a profissão de Tradutor e Intérprete da Língua Brasileira de Sinais - LIBRAS. Brasília-DF, 2010.

Decreto $\mathbf{n}^{0}$ 7.611, de 17 de novembro de 2011. Dispõe sobre a educação especial, o atendimento educacional especializado e dá outras providências. Brasília-DF, 2011.

Lei n⿳ 13.146, de 06 de julho de 2015. Lei Brasileira de Inclusão da Pessoa com Deficiência. Estatuto da Pessoa com Deficiência. Brasília-DF, 2015.

BRITO, L. F. et. al. Língua Brasileira de Sinais - LIBRAS. Secretaria de Educação Especial. Brasília-DF: SEESP, 1998.

CAPOVILLA, F. C. Filosofias educacionais em relação ao surdo: do oralismo à comunicação total ao bilinguismo. Revista Brasileira de Educação Especial, Marília-SP, v. 6, n. 1, p. 99$116,2000$.

CARTOLANO, M. T.. Formação do educador no curso de pedagogia: a educação especial. CEDES, Campinas-SP, n. 46, 1998.

CAVALLARI, J. S. Equívocos que constituem o macrodiscurso político-educacional da inclusão. In: FERREIRA, E. L.; ORLANDI, P. (Orgs.). Discurso sobre a inclusão. NiteróiRJ: Ed. Intertexto, 2014.

CHIZZOTTI, A. Pesquisa em ciências humanas e sociais. 7. ed. São Paulo: Cortez, 2005. v. 16 , série 1.

CONVENÇÃO DE GUATEMALA. Convenção Interamericana para a eliminação de todas as formas de discriminação contra as pessoas portadoras de deficiência. Guatemala, 28 maio1999.

CURY, M. S. A injunção ao novo e a repetição do velho: um olhar discursivo ao Programa Um Computador por Aluno (PROUCA). 2012. Tese (Doutorado) - universidade Estadual de Campinas, Instituto de Estudos da Linguagem, Campinas-SP, 2012.

CURY, Carlos Roberto Jamil. A educação escolar, a exclusão e seus destinatários - InEducação e Revista, n. 48, p. 205 - 222. Belo Horizonte, 2008.

DECLARAÇÃO DE SALAMANCA. Linha de ação sobre necessidades educativas especiais. Brasília-DF: CORDE, 1994. 
DIAS, C. Telecentros como políticas públicas de inclusão digital: da administração da vida na cidade. In: ORLANDI, E. (Coord.). $4^{\circ}$ Relatório parcial, projeto temático a produção do consenso nas políticas públicas urbanas. Entre o Administrativo e o jurídico (CAel). FAPESP, 2008.

A escrita como tecnologia da linguagem. Tecnologias de linguagem e produção do conhecimento. Santa Maria: UFSC, 2009. v. 2. Coleção hiper Saberes.

- O ensino, a leitura e a escrita: sobre conectividade e mobilidade. Campinas, 2011.

Entremeios: revista de estudos do discurso, v. 9, jul., 2011.

Tecnologia de linguagem e existência: a escrita afetada pela materialidade digital.

Revista Fragmentum, Santa Maria, Programa de Pós-Graduação em Letras, UFSM, n. 48, jul.- dez. 2016.

FERNANDES, C. A. Análise do Discurso: reflexões introdutórias. 2. ed. São Carlos: Editora Claraluz, 2008.

FERNANDES, Sueli. Critérios diferenciados de avaliação na língua portuguesa para estudantes surdos. 2. ed. Curitiba: SEED/SUED/DEE, 2006.

Educação de Surdos. Curitiba: Inter Saberes, 2012.

FERREIRA, A. B. de H.. Dicionário Aurélio Básico da Língua Portuguesa. Rio de Janeiro: Editora Positivo, 2010.

FERREIRO, E. Alfabetização em Processo. São Paulo: Ed. Cortez, 1996.

Com Todas as Letras. São Paulo: Ed. Cortez, 1999.v. 2.

GALLO, S. Novas Fronteiras para a Autoria. Revista Organon, PortoAlegre, n. 53, p. 53-64, 2012.

GALVÃO FILHO, T. A. A Tecnologia Assistiva: de que se trata? In: MACHADO, G. J. C.; SOBRAL, M. N. (Orgs.). Conexões: educação, comunicação, inclusão e interculturalidade. Redes Editora, p. 207-235. Porto Alegre, 2009.

Tecnologia assistiva e salas de recursos: análise crítica de um modelo. In: GALVÃO FILHO, T. A.; MIRANDA, T. G. (Orgs.). O professor e a educação inclusiva: formação, práticas e lugares. Salvador-BA: Editora da Universidade Federal da Bahia - EDUFBA, 2012.

GUARINELlO, A. C. O papel do outro na escrita de sujeitos Surdos. São Paulo: Plexos, 2004.

HALL, Stuart. A centralidade da cultura: notas sobre as revoluções culturais do nosso tempo. Revista Educação \& Realidade, p. 1-23, 1997.

HELLER, A. O cotidiano e a história. Rio de Janeiro: Paz e Terra, 2000. 
HENRY, P. Os fundamentos teóricos da "análise automática do discurso" de Michel Pêcheux. 1996. In: GADET, F.; HAK, T. (Orgs.). Por uma análise automática do discurso: uma introdução à obra de Michel Pêcheux. 4. ed. Tradução de Bethania S. Marianiet al. Campinas, SP: Editora da Unicamp, 2010.

HONORA, M. Livro ilustrado de língua brasileira de sinais. São Paulo: Ciranda Cultural, 2009.

KLEIMAN, A. B. Modelos de letramento e as práticas de alfabetização na escola. In: KLEIMAN, A. B. (Org.). Os significados do letramento: uma nova perspectiva sobre a prática social da escrita. Campinas: Mercado de Letras, 1995.

LACERDA, C. B. F. de. Um pouco da história de diferentes abordagens na educação de surdos. Cadernos CEDES, Campinas, UNICAMP, v. 19, 1998.

- Intérprete de LIBRAS: em atuação na educação infantil e no ensino fundamental. Porto Alegre: Mediação, FAPESP, 2009.

LAGAZZI, S. O desafio de dizer não. Campinas, SP: Pontes, 1988.

LEVINAS, Emmanuel. Ensaios sobre a Alteridade. Tradução Pergentino Stefano Pivatto. Petrópolis: Vozes, 1997.

LODI A. C. B. Plurilinguísmo e surdez: uma leitura Bakhtiniana da educação de Surdos. Educação e Pesquisa, São Paulo, v. 3,2005.

LOPES, M. C.; MENEZES, E.da C. P. de. Inclusão de alunos surdos na escola regular. Cadernos de Educação, Pelotas, FaE/PPGE/UFPel, n. 36, p. 69 -90, maio/agosto, 2010.

LUDKE, M.; ANDRÉ, M.E.D.A. Pesquisa em educação: abordagens qualitativas. São Paulo: EPU, 1986.

MANTOAN, M. T. et al. A educação especial na perspectiva da inclusão escolar: a escola comum inclusiva. Brasília: Ministério da Educação, 2010.v. 1.

MANZINI, J. E. Tecnologia assistiva para educação: recursos pedagógicos adaptados. Ensaios pedagógicos: construindo escolas inclusivas. Coordenação Geral de Denise de Oliveira Alves. Ministério da Educação. Secretaria de Educação Especial. Brasília-DF, 2005.

MARTINS, V. R. de O. Educação de surdos no paradoxo da inclusão com intérprete de língua de sinais: relações de poder e (re)criações do sujeito. Dissertação (Mestrado em Educação) - Universidade Estadual de Campinas, Campinas-SP, 2008.

MASSMANN, D. Acessibilidade: sentidos em movimento. In: FERREIRA, E. L.; ORLANDI P. (Orgs.). Discurso sobre a inclusão. Niteroi-RJ: Ed. Intertexto, 2014.

MUSSALIN F.; BENTES, A. C. Introdução à linguística: fundamentos epistemológicos. 3. ed. São Paulo: Cortez, 2007.v. 3. 
ORLANDI, E. P. A linguagem e seu funcionamento: as formas do discurso. 4.ed. Campinas-SP: Pontes, 1996.

A leitura e os leitores. Campinas-SP: Ed. Pontes, 1998.

A Análise de discurso em suas diferentes tradições intelectuais: o Brasil. SEMINÁRIO DE ESTUDOS EM ANÁLISE DE DISCURSO. Anais... Porto Alegre (RS), UFRGS, 2003.

Cidade dos Sentidos. Campinas-SP: Ed. Pontes, 2004.

. Introdução às ciências da linguagem. In: LAGAZZI, S. R.; ORLANDI, E. P. (Orgs.) Discurso e Textualidade. Campinas-SP: Pontes Editores, 2006.

As formas do silêncio: no movimento dos sentidos. 6. ed. Campinas-SP: Editora Unicamp, 2007a. $2007 b$.

Interpretação: autoria, leitura e efeitos do trabalho simbólico. Petrópolis: Vozes, Cap. X.

O que é linguística? 2. ed. São Paulo: Brasiliense, 2009.Coleção Primeiros Passos.

Discurso e Texto: formulação e circulação dos sentidos. 4. ed. Campinas-SP: Pontes Editores, 2012a.

Discurso e Leitura. 9.ed. São Paulo: Cortez, 2012b.

Editora, 2015a.

Análise do Discurso: princípios e procedimentos. 12.ed. Campinas-SP: Pontes

Discurso em Análise: sujeito, sentido e ideologia. 3.ed. Campinas-SP: Pontes Editores, 2016.

PÊCHEUX, Michel. Semântica e Discurso: uma crítica à afirmação do óbvio. 2.ed. Campinas-SP: Unicamp, 2009.

- O discurso: estrutura ou acontecimento. 7.ed. Tradução de Eni P. Orlandi. Campinas-SP: Pontes Editores, 2015.

PEIXOTO, R. C. Algumas considerações sobre a interface entre a Língua Brasileira de Sinais (LIBRAS) e a Língua Portuguesa na construção inicial da escrita pela criança surda. Cadernos CEDES, Campinas, n. 69, v. 26, 2006.

PENIN, S. Cotidiano e escola: a obra em construção. 2.ed. São Paulo: Cortez, 2011.

PERLIN, G. Identidades surdas. In: SKLIAR, Carlos (Org.). A Surdez: um olhar sobre as diferenças. Porto Alegre: Editora Mediação, 1998. 
Surdos: cultura e pedagogia. In: THOMAS, Adriana da Silva; LOPES, Maura Corcini (Orgs.). A invenção da Surdez II: espaços e tempos de aprendizagem na educação de surdos. Santa Cruz do Sul: EDUNISC, 2006.

POSSENTI, S. Teoria do discurso: um caso de múltiplas rupturas. In: MUSSALIN F.;BENTES, A. (Orgs.).Introdução à linguística: fundamentos epistemológicos. São Paulo: Cortez, 2004.v. 3.

QUADROS, R. M. de; KARNOPP, L. Língua de sinais brasileira: estudos linguísticos. Porto Alegre: Artmed Editora, 2004.

Educação de Surdos: aquisição da linguagem. Porto Alegre: Artmed Editora, 2006.

QUADROS, R. M. de. As categorias vazias pronominais: uma análise alternativa com base na LIBRAS e reflexos no processo de aquisição.1995. Dissertação (Mestrado) - Pontifícia Universidade Católica do Rio Grande do Sul, Porto Alegre, 1995.

. Alfabetização e o ensino da língua de sinais. Textura, Canoas, n.3, 2000.

Situando as diferenças implicadas na educação de surdos: inclusão/exclusão. Revista Ponto de Vista, Florianópolis, n.5, p. 81-111, 2003.

O tradutor e intérprete de língua brasileira de sinais e língua portuguesa. Brasília, DF: MEC, 2004.

2005.

O bi do bilinguismo na educação de surdos. Porto Alegre: Editora Mediação,

Ideias para ensinar português para alunos Surdos. Brasília: MEC, SEESP, 2006.

QUADROS, R. M. de; MOURA, E.. Multiletramentos na escola. São Paulo: Editorial Parábola, 2012.

REIS, V. P. F. A criança surda e seu mundo: o estado-da-arte, as políticas e as intervenções necessárias. 1992. Dissertação (Mestrado)- Universidade Federal do Espírito Santo, 1992.

DP\&A, 2003.

Pedagogia (improvável) da diferença: e se o outro não estivesse aí? Rio de Janeiro:

A Surdez: um olhar sobre as diferenças. 3.ed. Porto Alegre: Ed. Mediação, 2005.

ROJO, R. Letramentos múltiplos, escola e inclusão social. São Paulo: Editorial Parábola, 2009.

SKLIAR, C. (Org). Educação e Exclusão: abordagens sócio-antropológicas em educação especial. Porto Alegre: Mediação, 1997.

STRAUB, S. L.W.. Estratégias, desafios e perspectivas do uso da informática na educação: realidade na escola pública. Cáceres-MT: Editora UNEMAT, 2009. 
STROBEL, K. L; FERNANDES, S. Aspectos linguísticos da Língua Brasileira de Sinais. Curitiba: SEED/SUED/DEE, 1998.

As imagens do outro sobre a cultura surda. Florianópolis: Editora UFSC, 2008.

SÁ, N. R. L. de. Educação de surdos: a caminho do bilinguismo. Niterói-RJ: Ed. EDUFF, 1999.

Cultura, Poder e Educação de Surdos. Manaus: Editora da UFAM, 2003.

SACKS, O. Vendo vozes: uma jornada pelo mundo dos surdos. Rio de Janeiro: Companhia das letras, 1998.

SALLES, H. M. M. L. et al. Ensino de língua portuguesa para surdos: caminhos para a prática pedagógica. Programa Nacional de Apoio à Educação dos Surdos. Brasília: MEC, SEEESP, 2004.v. 2.

SANTAROSA, L. M. C. "Escola Virtual" para a Educação Especial: ambientes de aprendizagem telemáticos cooperativos como alternativa de desenvolvimento. Revista Integração, Brasília, MEC, n. 13, 2001.

SANTOS, D. A. do N. Tecnologia Assistiva, Acessibilidade e Formação de Professores: perspectivas de inclusão escolar. Anais... Evento/CD - ISSN 2175-8778, UNEMAT, 2013.v. II.

SANTOS, L. I. S. et al. (Orgs). Educação e tecnologias digitais da informação e comunicação: discursos, práticas, análises e desafios. Cáceres-MT: Editora UNEMAT, 2014.

SAUSSURE, F. de. Curso de Linguística Geral. 1916. Organizado por Charles Bally e Albert Sechehay e com a colaboração de Albert Riedlinger. 27ed. São Paulo: Editora Cultrix, 2006.

SILVA, T. T.da. Documentos de Identidade: uma introdução às teorias do currículo. Belo Horizonte: Editora Autêntica, 1999.

SILVA, A. B. de P.; PEREIRA, M. C. da C. O aluno surdo na escola regular: imagem e ação do professor. Psicologia: teoria e pesquisa, Brasília, v. 19, 2003.

SILVA, M. V.da. História da Alfabetização no Brasil: sentidos e sujeito da escolarização. Campinas: Editora da Unicamp, 2015.

O político na Análise do Discurso: contradição, silenciamento, resistência. VIII SEAD, Recife, 12 a 15 set. 2017.

SOARES, M. Letramento: um tema em três gêneros. Belo Horizonte: Autêntica, 1998.

Aprender a escrever, ensinar a escrever. In: ZACCUR, E. A magia da linguagem. Rio de Janeiro, 1999.

Alfabetização e Letramento: caminhos e descaminhos. Revista Pátio, n.29, 2004. 
SOUZA. R. M. de. Que palavra que te fala? Linguística, educação e surdez: considerações epistemológicas a partir da surdez. São Paulo: Martins Fontes, 1998.

SOUZA, R. M. de; GOÉS, M. C. R. O ensino para surdos na escola inclusiva: considerações sobre o excludente contexto da inclusão. In: SKLIAR, C. (Org.). Atualidades da educação bilíngue para surdos. Porto Alegre: Editora Mediação, 1999.

TFOUNI, L. V.. Letramento e Alfabetização. 9.ed. São Paulo: Editora Cortez, 2010. Coleção Questões da nossa Época. v. 15.

TARDIF, M. Saberes docentes e formação profissional. Rio de Janeiro: Vozes, 2002.

TRIVIÑOS, A. N. S. Introdução à Pesquisa em Ciências Sociais: a pesquisa qualitativa em educação. 14 Reimp. São Paulo: Atlas, 2006. 


\section{REFERÊNCIAS WEBGRÁFICAS}

BRASIL. Constituição da República Federativa do Brasil. Brasília, 1988.

Disponívelem:<http://www.planalto.gov.br/ccivil_03/constituicao/constituicaocompilado.htm $>$. Acesso em 2 fev. 2018.

Lei n. 13.005, de 25 de junho de 2014. Aprova o Plano Nacional de Educação PNE e dá outras providências. Disponível em: <http://www.planalto.gov.br/ccivil_03/_ato2011-2014/2014/lei/113005.htm>. Acesso em: 15 fev. 2018.

Tecnologia assistiva. Subsecretaria Nacional de promoção dos direitos da pessoa com deficiência. Brasília: Editora Corde, 2009. Disponível em: <http://www.gpef.fe.usp.br/teses/agenda_20110_02.pdf>.Acesso em:8jan. 2018.

DECLARAÇÃO DE SALAMANCA. Sobre princípios, políticas e práticas na área das necessidades educativas especiais. Disponível em:

<http://portal.mec.gov.br/seesp/arquivos/pdf/salamanca.pdf.>.Acesso em: 14 jan. 2018.

FERNANDES, S. Conhecendo a surdez. In: BRASIL. Saberes e práticas da inclusão.

Dificuldades de comunicação e sinalização. Surdez. Educação infantil. Brasília: MEC/SEESP, 2013. Disponível em:

<http://www.diaadiaeducacao.pr.gov.br/portals/portal/institucional/dee/dee_surdez.php>. Acesso em: 10 mar. 2018.

. Decreto n ${ }^{\circ} 3.956$, de 08 de outubro de 2001. Convenção da organização dos Estados Americanos. Disponível em:

<http://portal.mec.gov.br/seesp/arquivos/pdf/guatemala.pdf>.Acesso em: 22 mar. 2018.

FENEIS. A história da comunidade surda. Disponível em:

<http://www.feneis.org.br>.Acesso em: 23 mar. 2018.

LIBRAS em estudo: descrição e analise. Disponível em:

<http://www.feneis.org.br>. Acesso em: 2 mar. 2018.

OCDE. Educationat a Glance 2016: Indicadores da OCDE. Coutry Notes: Brasil. Disponível em: <http://www.oecdbetterlifeindex.org/pt/quesitos/education-pt/>. Acesso em: $22 \mathrm{fev}$. 2018.

ORLANDI, E. P. Linguagem e educação social: a relação sujeito, indivíduo e pessoa. Revista RUA [online], n. 21, v. 2, p. 187-206 - ISSN 1413 - 2109, novembro 2015b.

Consultada no Portal Labeurb - Revista do Laboratório de Estudos Urbanos do Núcleo de Desenvolvimento da Criatividade. Disponível em:

<http://www.labeurb.unicamp.br/rua/>.Acesso em: 17 mar. 2018.

STROBEL, K. L. A visão histórica da in(ex)clusão dos surdos nas escolas.ETD - Educação Temática Digital, n. 2, v.7, 2006. Disponível em:

<http://143.106.58.55/revista/viewarticle.php?id=125\&layout=abstract $>$. Acesso em: 18 mar. 2018. 
ANEXOS 
Dispõe sobre a Língua Brasileira de Sinais LIBRAS e dá outras providências.

\section{O PRESIDENTE DA REPÚBLICA}

Faço saber que o Congresso Nacional decreta e eu sanciono a seguinte Lei: Art. $1^{\circ}$ É reconhecida como meio legal de comunicação e expressão a Língua Brasileira de Sinais - LIBRAS e outros recursos de expressão a ela associados.

Parágrafo único. Entende-se como Língua Brasileira de Sinais - LIBRAS a forma de comunicação e expressão, em que o sistema lingüístico de natureza visual-motora, com estrutura gramatical própria, constituem um sistema lingüístico de transmissão de idéias e fatos, oriundos de comunidades de pessoas surdas do Brasil.

Art. $2^{\circ}$ Deve ser garantido, por parte do poder público em geral e empresas concessionárias de serviços públicos, formas institucionalizadas de apoiar o uso e difusão da Língua Brasileira de Sinais - LIBRAS como meio de comunicação objetiva e de utilização corrente das comunidades surdas do Brasil.

Art. $3^{\circ}$ As instituições públicas e empresas concessionárias de serviços públicos de assistência à saúde devem garantir atendimento e tratamento adequado aos portadores de deficiência auditiva, de acordo com as normas legais em vigor.

Art. $4^{\circ} \mathrm{O}$ sistema educacional federal e os sistemas educacionais estaduais, municipais e do Distrito Federal devem garantir a inclusão nos cursos de formação de Educação Especial, de Fonoaudiologia e de Magistério, em seus níveis médio e superior, do ensino da Língua Brasileira de Sinais - LIBRAS, como parte integrante dos Parâmetros Curriculares Nacionais PCNs, conforme legislação vigente.

Parágrafo único. A Língua Brasileira de Sinais - LIBRAS não poderá substituir a modalidade escrita da língua portuguesa.

Art. $5^{\circ}$ Esta Lei entra em vigor na data de sua publicação.

Brasília, 24 de abril de 2002; $181^{\circ}$ da Independência e $114^{\circ}$ da República.

ANEXO B -DECRETO N 5.626, DE 22 DE DEZEMBRO DE 2005 
Que dispõe sobre a Língua Brasileira de Sinais - LIBRAS, e o art. 18 da Lei ${ }^{\circ} 10.098$, de 19 de dezembro de 2000.

O PRESIDENTE DA REPÚBLICA, no uso das atribuições que lhe confere o art. 84, inciso IV, da Constituição, e tendo em vista o disposto na Lei ${ }^{\circ} 10.436$, de 24 de abril de 2002, e no art. 18 da Lei n $^{\circ} 10.098$, de 19 de dezembro de 2000,

\section{DECRETA:}

\section{CAPÍTULO I}

\section{DAS DISPOSIÇÕES PRELIMINARES}

Art. $1^{\circ}$ Este Decreto regulamenta a Lei ${ }^{\circ} 10.436$, de 24 de abril de 2002, e o art.18 da Lei $\mathrm{n}^{\circ} 10.098$, de 19 de dezembro de 2000.

Art. $2^{\circ}$ Para os fins deste Decreto, considera-se pessoa surda aquela que, por ter perda auditiva compreende e interage com o mundo por meio de experiências visuais, manifestando sua cultura principalmente pelo uso da Língua Brasileira de Sinais - LIBRAS.

Parágrafo único. Considera-se deficiência auditiva a perda bilateral, parcial ou total , de quarenta e um decibéis $(\mathrm{dB})$ ou mais, aferida por audiograma nas frequências de $500 \mathrm{~Hz}$, $1.000 \mathrm{~Hz}, 2.000 \mathrm{~Hz}$ e $3.000 \mathrm{~Hz}$.

\section{CAPÍTULO II DA INCLUSÃO DA LIBRAS COMO DISCIPLINA CURRICULAR}

Art. $3^{\circ}$ - A LIBRAS deve ser inserida como disciplina curricular obrigatória nos cursos de formação de professores para o exercício do magistério, em nível médio e superior, e nos cursos de Fonoaudiologia, de instituições de ensino, públicas e privadas, do sistema federal de ensino e dos sistemas de ensino dos Estados, do Distrito Federal e dos Municípios.

$\S 1^{\mathrm{o}}$ Todos os cursos de licenciatura, nas diferentes áreas do conhecimento, o curso normal de nível médio, o curso normal superior, o curso de Pedagogia e o curso de Educação Especial são considerados cursos de formação de professores e profissionais da educação para o exercício do magistério.

$\S 2^{\underline{o}}$ A LIBRASconstituir-se-á em disciplina curricular optativa nos demais cursos de educação superior e na educação profissional, a partir de um ano da publicação deste Decreto.

\section{CAPÍTULO III \\ DA FORMAÇÃO DO PROFESSOR DE LIBRAS E DO INSTRUTOR DE LIBRAS}

Art. $4^{\circ}$ A formação de docentes para o ensino de LIBRAS nas séries finais do ensino fundamental, no ensino médio e na educação superior deve ser realizada em nível superior, em curso de graduação de licenciatura plena em Letras: LIBRASou em Letras: LIBRAS/Língua Portuguesa como segunda língua. 

no caput

Parágrafo único. As pessoas surdas terão prioridade nos cursos de formação previstos

Art. $5^{-}$A formação de docentes para o ensino de LIBRAS na educação infantil e nos anos iniciais do ensino fundamental deve ser realizada em curso de Pedagogia ou curso normal superior, em que LIBRAS e Língua Portuguesa escrita tenham constituído línguas de instrução, viabilizando a formação bilíngue.

$\S 1^{\underline{0}}$ Admite-se como formação mínima de docentes para o ensino de LIBRAS na educação infantil e nos anos iniciais do ensino fundamental, a formação ofertada em nível médio na modalidade normal, que viabilizar a formação bilíngue, referida no caput.

$\S 2^{\underline{0}}$ As pessoas surdas terão prioridade nos cursos de formação previstos no caput.

Art. $6^{\circ}$ A formação de instrutor de LIBRAS, em nível médio, deve ser realizada por meio de:

I - cursos de educação profissional;

II - cursos de formação continuada promovidos por instituições de ensino superior; e

III - cursos de formação continuada promovidos por instituições credenciadas por secretarias de educação.

$\S 1^{0}$ A formação do instrutor de LIBRAS pode ser realizada também por organizações da sociedade civil representativa da comunidade surda, desde que o certificado seja convalidado por pelo menos uma das instituições referidas nos incisos II e III.

$\S 2^{\underline{o}}$ As pessoas surdas terão prioridade nos cursos de formação previstos no caput.

Art. $7^{\circ}$ Nos próximos dez anos, a partir da publicação deste Decreto, caso não haja docente com título de pós-graduação ou de graduação em LIBRAS para o ensino dessa disciplina em cursos de educação superior, ela poderá ser ministrada por profissionais que apresentem pelo menos um dos seguintes perfis:

I - professor de LIBRAS, usuário dessa língua com curso de pós-graduação ou com formação superior e certificado de proficiência em LIBRAS, obtido por meio de exame promovido pelo Ministério da Educação;

II - instrutor de LIBRAS, usuário dessa língua com formação de nível médio e com certificado obtido por meio de exame de proficiência em LIBRAS, promovido pelo Ministério da Educação;

III - professor ouvinte bilíngue: LIBRAS - Língua Portuguesa, com pós-graduação ou formação superior e com certificado obtido por meio de exame de proficiência em LIBRAS, promovido pelo Ministério da Educação.

$\S 1^{\circ}$ Nos casos previstos nos incisos I e II, as pessoas surdas terão prioridade para ministrar a disciplina de LIBRAS. 
$\S 2^{\underline{o}}$ A partir de um ano da publicação deste Decreto, os sistemas e as instituições de ensino da educação básica e as de educação superior devem incluir o professor de LIBRAS em seu quadro do magistério.

Art. $8^{\circ} \mathrm{O}$ exame de proficiência em LIBRAS, referido no art. $7^{\circ}$, deve avaliar a fluência no uso, o conhecimento e a competência para o ensino dessa língua.

$\S 1^{\underline{0}} \mathrm{O}$ exame de proficiência em LIBRAS deve ser promovido, anualmente, pelo Ministério da Educação e instituições de educação superior por ele credenciadas para essa finalidade.

$\S 2^{\underline{0}}$ A certificação de proficiência em LIBRAS habilitará o instrutor ou o professor para a função docente.

$\S 3^{0} \mathrm{O}$ exame de proficiência em LIBRAS deve ser realizado por banca examinadora de amplo conhecimento em LIBRAS, constituída por docentes surdos e linguistas de instituições de educação superior.

Art. $9^{\circ}$ A partir da publicação deste Decreto, as instituições de ensino médio que oferecem cursos de formação para o magistério na modalidade normal e as instituições de educação superior que oferecem cursos de Fonoaudiologia ou de formação de professores devem incluir LIBRAS como disciplina curricular, nos seguintes prazos e percentuais mínimos

I - até três anos, em vinte por cento dos cursos da instituição;

II - até cinco anos, em sessenta por cento dos cursos da instituição;

III - até sete anos, em oitenta por cento dos cursos da instituição; e

IV - dez anos, em cem por cento dos cursos da instituição.

Parágrafo único. O processo de inclusão da LIBRAS como disciplina curricular deve iniciar-se nos cursos de Educação Especial, Fonoaudiologia, Pedagogia e Letras, ampliandose progressivamente para as demais licenciaturas.

Art. 10. As instituições de educação superior devem incluir a LIBRAS como objeto de ensino, pesquisa e extensão nos cursos de formação de professores para a educação básica, nos cursos de Fonoaudiologia e nos cursos de Tradução e Interpretação de LIBRAS - Língua Portuguesa.

Art. 11. O Ministério da Educação promoverá, a partir da publicação deste Decreto, programas específicos para a criação de cursos de graduação:

I - para formação de professores surdos e ouvintes, para a educação infantil e anos iniciais do ensino fundamental, que viabilize a educação bilíngue: LIBRAS - Língua Portuguesa como segunda língua;

II - de licenciatura em Letras: LIBRAS ou em Letras: LIBRAS/Língua Portuguesa, como segunda língua para surdos; 
III - de formação em Tradução e Interpretação de LIBRAS - Língua Portuguesa.

Art. 12. As instituições de educação superior, principalmente as que ofertam cursos de Educação Especial, Pedagogia e Letras, devem viabilizar cursos de pós-graduação para a formação de professores para o ensino de LIBRAS e sua interpretação, a partir de um ano da publicação deste Decreto.

Art. 13. O ensino da modalidade escrita da Língua Portuguesa, como segunda língua para pessoas surdas, deve ser incluído como disciplina curricular nos cursos de formação de professores para a educação infantil e para os anos iniciais do ensino fundamental, de nível médio e superior, bem como nos cursos de licenciatura em Letras com habilitação em Língua Portuguesa.

Parágrafo único. O tema sobre a modalidade escrita da língua portuguesa para surdos deve ser incluído como conteúdo nos cursos de Fonoaudiologia.

\section{CAPÍTULO IV \\ DO USO E DA DIFUSÃO DA LIBRAS E DA LÍNGUA PORTUGUESA PARA O ACESSO DAS PESSOAS SURDAS À EDUCAÇÃO}

Art. 14. As instituições federais de ensino devem garantir, obrigatoriamente, às pessoas surdas acesso à comunicação, à informação e à educação nos processos seletivos, nas atividades e nos conteúdos curriculares desenvolvidos em todos os níveis, etapas e modalidades de educação, desde a educação infantil até à superior.

$\S 1^{\underline{o}}$ Para garantir o atendimento educacional especializado e o acesso previsto no caput, as instituições federais de ensino devem:

I - promover cursos de formação de professores para:

a) o ensino e uso da LIBRAS;

b) a tradução e interpretação de LIBRAS - Língua Portuguesa; e

c) o ensino da Língua Portuguesa, como segunda língua para pessoas surdas;

II - ofertar, obrigatoriamente, desde a educação infantil, o ensino da LIBRAS e também da Língua Portuguesa, como segunda língua para alunos surdos;

III - prover as escolas com:

a) professor de LIBRAS ou instrutor de LIBRAS;

b) tradutor e intérprete de LIBRAS - Língua Portuguesa;

c) professor para o ensino de Língua Portuguesa como segunda língua para pessoas surdas; e

d) professor regente de classe com conhecimento acerca da singularidade linguística manifestada pelos alunos surdos; 
IV - garantir o atendimento às necessidades educacionais especiais de alunos surdos, desde a educação infantil, nas salas de aula e, também, em salas de recursos, em turno contrário ao da escolarização;

V - apoiar, na comunidade escolar, o uso e a difusão de LIBRAS entre professores, alunos, funcionários, direção da escola e familiares, inclusive por meio da oferta de cursos;

VI - adotar mecanismos de avaliação coerentes com aprendizado de segunda língua, na correção das provas escritas, valorizando o aspecto semântico e reconhecendo a singularidade linguística manifestada no aspecto formal da Língua Portuguesa;

VII - desenvolver e adotar mecanismos alternativos para a avaliação de conhecimentos expressos em LIBRAS, desde que devidamente registrados em vídeo ou em outros meios eletrônicos e tecnológicos;

VIII - disponibilizar equipamentos, acesso às novas tecnologias de informação e comunicação, bem como recursos didáticos para apoiar a educação de alunos surdos ou com deficiência auditiva.

$\S 2^{\circ}$ O professor da educação básica, bilíngüe, aprovado em exame de proficiência em tradução e interpretação de LIBRAS - Língua Portuguesa, pode exercer a função de tradutor e intérprete de LIBRAS - Língua Portuguesa, cuja função é distinta da função de professor docente.

$\S 3^{0}$ As instituições privadas e as públicas dos sistemas de ensino federal, estadual, municipal e do Distrito Federal buscarão implementar as medidas referidas neste artigo como meio de assegurar atendimento educacional especializado aos alunos surdos ou com deficiência auditiva.

Art. 15. Para complementar o currículo da base nacional comum, o ensino de LIBRAS e o ensino da modalidade escrita da Língua Portuguesa, como segunda língua para alunos surdos, devem ser ministrados em uma perspectiva dialógica, funcional e instrumental, como:

I - atividades ou complementação curricular específica na educação infantil e anos iniciais do ensino fundamental; e

II - áreas de conhecimento, como disciplinas curriculares, nos anos finais do ensino fundamental, no ensino médio e na educação superior.

Art. 16. A modalidade oral da Língua Portuguesa, na educação básica, deve ser ofertada aos alunos surdos ou com deficiência auditiva, preferencialmente em turno distinto ao da escolarização, por meio de ações integradas entre as áreas da saúde e da educação, resguardado o direito de opção da família ou do próprio aluno por essa modalidade.

Parágrafo único. A definição de espaço para o desenvolvimento da modalidade oral da Língua Portuguesa e a definição dos profissionais de Fonoaudiologia para atuação com alunos da educação básica são de competência dos órgãos que possuam estas atribuições nas unidades federadas. 


\section{CAPÍTULO V \\ DA FORMAÇÃO DO TRADUTOR E INTÉRPRETE DE LIBRAS - LÍNGUA PORTUGUESA}

Art. 17. A formação do tradutor e intérprete de LIBRAS - Língua Portuguesa deve efetivar-se por meio de curso superior de Tradução e Interpretação, com habilitação em LIBRAS - Língua Portuguesa.

Art. 18. Nos próximos dez anos, a partir da publicação deste Decreto, a formação de tradutor e intérprete de LIBRAS - Língua Portuguesa, em nível médio, deve ser realizada por meio de:

I - cursos de educação profissional;

II - cursos de extensão universitária; e

III - cursos de formação continuada promovidos por instituições de ensino superior e instituições credenciadas por secretarias de educação.

Parágrafo único. A formação de tradutor e intérprete de LIBRAS pode ser realizada por organizações da sociedade civil representativas da comunidade surda, desde que o certificado seja convalidado por uma das instituições referidas no inciso III.

Art. 19. Nos próximos dez anos, a partir da publicação deste Decreto, caso não haja pessoas com a titulação exigida para o exercício da tradução e interpretação de LIBRAS Língua Portuguesa, as instituições federais de ensino devem incluir, em seus quadros, profissionais com o seguinte perfil:

I - profissional ouvinte, de nível superior, com competência e fluência em LIBRAS para realizar a interpretação das duas línguas, de maneira simultânea e consecutiva, e com aprovação em exame de proficiência, promovido pelo Ministério da Educação, para atuação em instituições de ensino médio e de educação superior;

II - profissional ouvinte, de nível médio, com competência e fluência em LIBRAS para realizar a interpretação das duas línguas, de maneira simultânea e consecutiva, e com aprovação em exame de proficiência, promovido pelo Ministério da Educação, para atuação no ensino fundamental;

III - profissional surdo, com competência para realizar a interpretação de línguas de sinais de outros países para a LIBRAS, para atuação em cursos e eventos.

Parágrafo único. As instituições privadas e as públicas dos sistemas de ensino federal, estadual, municipal e do Distrito Federal buscarão implementar as medidas referidas neste artigo como meio de assegurar aos alunos surdos ou com deficiência auditiva o acesso à comunicação, à informação e à educação.

Art. 20. Nos próximos dez anos, a partir da publicação deste Decreto, o Ministério da Educação ou instituições de ensino superior por ele credenciadas para essa finalidade promoverão, anualmente, exame nacional de proficiência em tradução e interpretação de LIBRAS - Língua Portuguesa. 
Parágrafo único. O exame de proficiência em tradução e interpretação de LIBRAS Língua Portuguesa deve ser realizado por banca examinadora de amplo conhecimento dessa função, constituída por docentes surdos, linguistas e tradutores e intérpretes de LIBRAS de instituições de educação superior.

Art. 21. A partir de um ano da publicação deste Decreto, as instituições federais de ensino da educação básica e da educação superior devem incluir, em seus quadros, em todos os níveis, etapas e modalidades, o tradutor e intérprete de LIBRAS - Língua Portuguesa, para viabilizar o acesso à comunicação, à informação e à educação de alunos surdos.

\section{$\S 1^{0}$ O profissional a que se refere o caput atuará:}

I - nos processos seletivos para cursos na instituição de ensino;

II - nas salas de aula para viabilizar o acesso dos alunos aos conhecimentos e conteúdos curriculares, em todas as atividades didático-pedagógicas; e

III - no apoio à acessibilidade aos serviços e às atividades-fim da instituição de ensino.

$\S 2^{0}$ As instituições privadas e as públicas dos sistemas de ensino federal, estadual, municipal e do Distrito Federal buscarão implementar as medidas referidas neste artigo como meio de assegurar aos alunos surdos ou com deficiência auditiva o acesso à comunicação, à informação e à educação.

\section{CAPÍTULO VI \\ DA GARANTIA DO DIREITO À EDUCAÇÃO DAS PESSOAS SURDAS OU COM DEFICIÊNCIA AUDITIVA}

Art. 22. As instituições federais de ensino responsáveis pela educação básica devem garantir a inclusão de alunos surdos ou com deficiência auditiva, por meio da organização de:

I - escolas e classes de educação bilíngue, abertas a alunos surdos e ouvintes, com professores bilíngues, na educação infantil e nos anos iniciais do ensino fundamental;

II - escolas bilíngues ou escolas comuns da rede regular de ensino, abertas a alunos surdos e ouvintes, para os anos finais do ensino fundamental, ensino médio ou educação profissional, com docentes das diferentes áreas do conhecimento, cientes da singularidade linguística dos alunos surdos, bem como com a presença de tradutores e intérpretes de LIBRAS - Língua Portuguesa.

$\S 1^{0}$ São denominadas escolas ou classes de educação bilíngue aquelas em que a LIBRAS e a modalidade escrita da Língua Portuguesa sejam línguas de instrução utilizadas no desenvolvimento de todo o processo educativo.

$\S 2^{\underline{0}}$ Os alunos têm o direito à escolarização em um turno diferenciado ao do atendimento educacional especializado para o desenvolvimento de complementação curricular, com utilização de equipamentos e tecnologias de informação. 
$\S 3^{0}$ As mudanças decorrentes da implementação dos incisos I e II implicam a formalização, pelos pais e pelos próprios alunos, de sua opção ou preferência pela educação sem o uso de LIBRAS.

$\S 4^{\circ} \mathrm{O}$ disposto no $\S 2^{\underline{0}}$ deste artigo deve ser garantido também para os alunos não usuários da LIBRAS.

Art. 23. As instituições federais de ensino, de educação básica e superior, devem proporcionar aos alunos surdos os serviços de tradutor e intérprete de LIBRAS - Língua Portuguesa em sala de aula e em outros espaços educacionais, bem como equipamentos e tecnologias que viabilizem o acesso à comunicação, à informação e à educação.

$\S 1^{\underline{0}}$ Deve ser proporcionado aos professores acesso à literatura e informações sobre a especificidade linguística do aluno surdo.

$\S 2^{\circ}$ As instituições privadas e as públicas dos sistemas de ensino federal, estadual, municipal e do Distrito Federal buscarão implementar as medidas referidas neste artigo como meio de assegurar aos alunos surdos ou com deficiência auditiva o acesso à comunicação, à informação e à educação.

Art. 24. A programação visual dos cursos de nível médio e superior, preferencialmente os de formação de professores, na modalidade de educação a distância, deve dispor de sistemas de acesso à informação como janela com tradutor e intérprete de LIBRAS - Língua Portuguesa e subtitulação por meio do sistema de legenda oculta, de modo a reproduzir as mensagens veiculadas às pessoas surdas, conforme prevê o Decreto $\mathrm{n}^{\mathrm{o}} 5.296$, de 2 de dezembro de 2004. 
ANEXO C - LEI N 12.319, DE $1^{\circ}$ DE SETEMBRO DE 2010

\author{
Regulamenta a profissão de Tradutor e \\ Intérprete da Língua Brasileira de Sinais - \\ LIBRAS.
}

O PRESIDENTE DA REPÚBLICA Faço saber que o Congresso Nacional decreta e eu sanciono a seguinte Lei:

Art. $1^{\mathrm{o}}$ Esta Lei regulamenta o exercício da profissão de Tradutor e Intérprete da Língua Brasileira de Sinais - LIBRAS.

Art. $2^{\underline{0}} \mathrm{O}$ tradutor e intérprete terá competência para realizar interpretação das 2 (duas) línguas de maneira simultânea ou consecutiva e proficiência em tradução e interpretação da LIBRAS e da Língua Portuguesa.

\title{
Art. $3^{-} \underline{\text { (VETADO) }}$
}

Art. $4^{0}$ A formação profissional do tradutor e intérprete de LIBRAS - Língua Portuguesa, em nível médio, deve ser realizada por meio de:

I - cursos de educação profissional reconhecidos pelo Sistema que os credenciou;

II - cursos de extensão universitária; e

III - cursos de formação continuada promovidos por instituições de ensino superior e instituições credenciadas por Secretarias de Educação.

Parágrafo único. A formação de tradutor e intérprete de LIBRAS pode ser realizada por organizações da sociedade civil representativas da comunidade surda, desde que o certificado seja convalidado por uma das instituições referidas no inciso III.

Art. 5ำ Até o dia 22 de dezembro de 2015, a União, diretamente ou por intermédio de credenciadas, promoverá, anualmente, exame nacional de proficiência em Tradução e Interpretação de LIBRAS - Língua Portuguesa.

Parágrafo único. O exame de proficiência em Tradução e Interpretação de LIBRAS Língua Portuguesa deve ser realizado por banca examinadora de amplo conhecimento dessa função, constituída por docentes surdos, linguistas e tradutores e intérpretes de LIBRAS de instituições de educação superior.

Art. $6^{0}$ São atribuições do tradutor e intérprete, no exercício de suas competências:

I - efetuar comunicação entre surdos e ouvintes, surdos e surdos, surdos e surdos-cegos, surdos-cegos e ouvintes, por meio da LIBRAS para a língua oral e vice-versa;

II - interpretar, em Língua Brasileira de Sinais - Língua Portuguesa, as atividades didático-pedagógicas e culturais desenvolvidas nas instituições de ensino nos níveis fundamental, médio e superior, de forma a viabilizar o acesso aos conteúdos curriculares; 
III - atuar nos processos seletivos para cursos na instituição de ensino e nos concursos públicos;

IV - atuar no apoio à acessibilidade aos serviços e às atividades-fim das instituições de ensino e repartições públicas; e

V - prestar seus serviços em depoimentos em juízo, em órgãos administrativos ou policiais.

Art. $7^{0} \mathrm{O}$ intérprete deve exercer sua profissão com rigor técnico, zelando pelos valores éticos a ela inerentes, pelo respeito à pessoa humana e à cultura do surdo e, em especial:

I - pela honestidade e discrição, protegendo o direito de sigilo da informação recebida;

II - pela atuação livre de preconceito de origem, raça, credo religioso, idade, sexo ou orientação sexual ou gênero;

III - pela imparcialidade e fidelidade aos conteúdos que lhe couber traduzir;

IV - pelas posturas e conduta adequadas aos ambientes que frequentar por causa do exercício profissional;

V - pela solidariedade e consciência de que o direito de expressão é um direito social, independentemente da condição social e econômica daqueles que dele necessitem;

VI - pelo conhecimento das especificidades da comunidade surda.

Art. $8^{\underline{0}}$ (VETADO)

Art. $9^{0}$ (VETADO)

Art. 10. Esta Lei entra em vigor na data de sua publicação.

Brasília, 1ำ de setembro de 2010; $189^{\circ}$ da Independência e $122^{\circ}$ da República.

\author{
LUIZ INÁCIO LULA DA SILVA \\ Luiz Paulo Teles Ferreira Barreto \\ Fernando Haddad \\ Carlos Lupi \\ Paulo de Tarso Vanucchi
}

